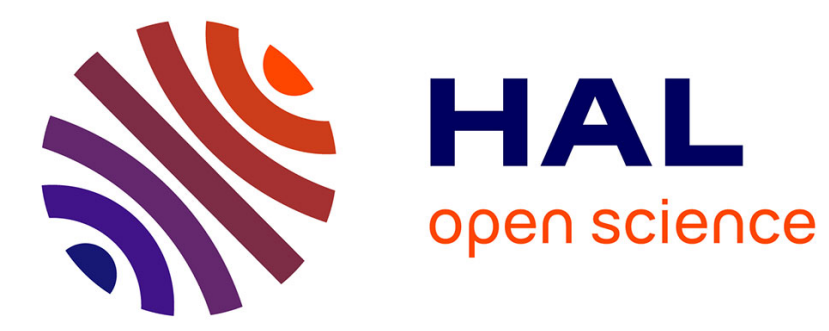

\title{
Arab Spring Protests and Women's Labor Market Outcomes: Evidence from the Egyptian Revolution
}

Nelly El-Mallakh, Mathilde Maurel, Biagio Speciale

\section{To cite this version:}

Nelly El-Mallakh, Mathilde Maurel, Biagio Speciale. Arab Spring Protests and Women's Labor Market Outcomes: Evidence from the Egyptian Revolution. 2016. hal-01309651

\section{HAL Id: hal-01309651 \\ https://hal-paris1.archives-ouvertes.fr/hal-01309651}

Preprint submitted on 29 Apr 2016

HAL is a multi-disciplinary open access archive for the deposit and dissemination of scientific research documents, whether they are published or not. The documents may come from teaching and research institutions in France or abroad, or from public or private research centers.
L'archive ouverte pluridisciplinaire HAL, est destinée au dépôt et à la diffusion de documents scientifiques de niveau recherche, publiés ou non, émanant des établissements d'enseignement et de recherche français ou étrangers, des laboratoires publics ou privés. 

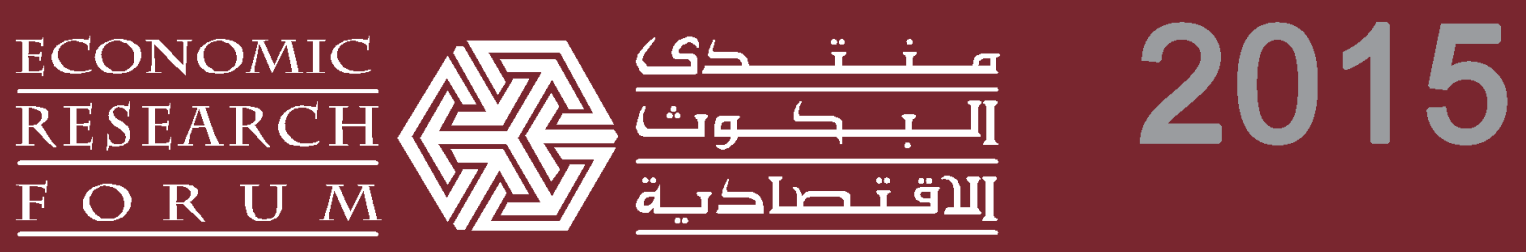

\title{
working paper series
}

ARAB SPRING PROTESTS AND WOMEN'S LABOR MARKET OUTCOMES:

\author{
EVIDENCE FROM THE EGYPTIAN REVOLUTION
}

Nelly El-Mallakh, Mathilde Maurel, and Biagio Speciale 


\title{
ARAB SPRING PROTESTS AND WOMEN'S LABOR MARKET OUTCOMES: EVIDENCE FROM THE EGYPTIAN REVOLUTION
}

\author{
Nelly El-Mallakh, Mathilde Maurel, and Biagio Speciale
}

Working Paper 957

October 2015

The authors gratefully acknowledge support from the Ferdi (Fondation pour les études et recherches sur le développement international). Ragui Assaad, Rémi Bazillier, Sonia Bhalotra, Lorenzo Cappellari, Jean-Pierre Laffargue, Marco Leonardi, Jeffrey Nugent, Mohamed Saleh, Michèle Tertilt and Jacqueline Wahba have provided valuable comments. The usual disclaimers apply. A previous version of this work circulates under the title "Women and Political Change: Evidence from the Egyptian Revolution’', FERDI working paper 116, December 1st, 2014.

\section{Send correspondence to:}

Nelly El-Mallakh

Centre d'Economie de la Sorbonne, Université Paris 1 Panthéon-Sorbonne

nelly.elmallakh@hotmail.com 
First published in 2015 by

The Economic Research Forum (ERF)

21 Al-Sad Al-Aaly Street

Dokki, Giza

Egypt

www.erf.org.eg

Copyright (C) The Economic Research Forum, 2015

All rights reserved. No part of this publication may be reproduced in any form or by any electronic or mechanical means, including information storage and retrieval systems, without permission in writing from the publisher.

The findings, interpretations and conclusions expressed in this publication are entirely those of the author(s) and should not be attributed to the Economic Research Forum, members of its Board of Trustees, or its donors. 


\begin{abstract}
We analyze the effects of the 2011 Egyptian protests on the relative labor market conditions of women using panel information from the Egypt Labor Market Panel Survey (ELMPS). We construct our measure of intensity of the protests - the governorate-level number of "martyrs" (i.e., demonstrators who died during the protests) - using unique information from the Statistical Database of the Egyptian Revolution. We find that the 2011 protests have reduced the gender gap in labor force participation by increasing women's unemployment and private sector employment. The political change has mostly affected the relative labor market outcomes of women in households at the bottom of the pre-revolution income distribution. We link these findings to the literature showing how a relevant shock to the labor division between women and men may have long run consequences on the role of women in society.
\end{abstract}

JEL Classifications: J16, J21, J22, J30.

Keywords: Egyptian protests, women’s labor market outcomes, “martyrs”.

\title{
ملخص
}

نقوم بتحليل الآثار المترتبة على الاحتجاجات المصـرية على أوضــاع سـوق العمل في عام 2011 بالنسـبة للمر أة باســخدام بيانات المسح التتبعى لسوق العمل فى مصر (ELMPS). نقوم ببناء مقياس لدينا من شدة الاحتجاجات ـ عدد الثـــداء" على مستوى كل

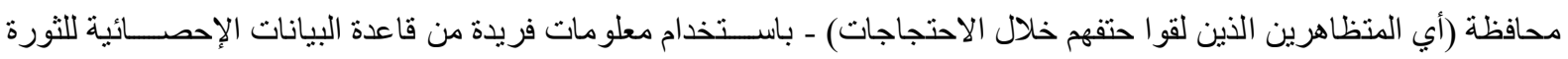
المصرية. نجد أن احتجاجات 2011 خفضت الفجوة بين الجنسين في المشاركة في القوى العاملة عن طريق زيادة البطالة بين النساء

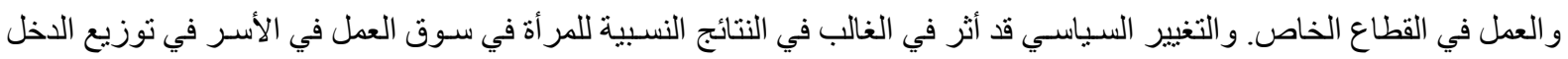

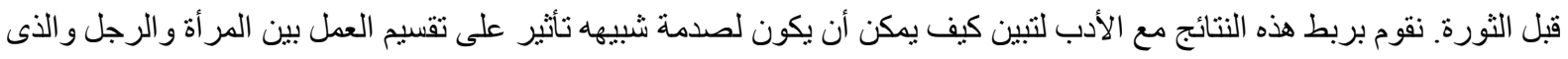

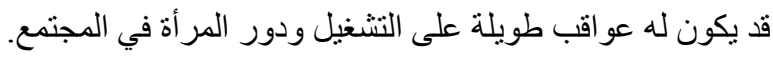




\section{Introduction}

Women's empowerment has been a central issue in the policy and academic debates in recent years. There is now a large consensus that empowering women may benefit economic development and is highly desirable for efficiency (see, for instance, United Nations, 2005; Duflo, 2012; Diebolt and Perrin, 2013). In the academic literature, a growing number of randomized experiments shed light on the effects of programs that aim at improving the status of women in several domains (see Beaman, Duflo, Pande and Topalova, 2012; Jensen, 2012; Beath, Christia and Enikopolov, 2013; Bandiera, Buehren, Burgess, Goldstein, Gulesci, Rasul and Sulaiman, 2014; Duflo, Dupas and Kremer, 2014).

Still, in many countries in the world, women lag behind men in several education and labor market outcomes. This is particularly true in the Arab World, where several countries are also experiencing, in recent years, a wave of protests and revolutions - known as the "Arab Spring" - mainly driven by poor labor market prospects for educated youth (Campante and Chor, 2012a). In this paper, we focus on Egypt, where former presidents Hosni Mubarak and Mohamed Morsi were removed from power in February 2011 and July 2013, respectively. Egypt is also a country with large gender segregation. The United Nations (2013) documents that it is ranked 77 out of 80 countries on the Gender Empowerment Measure and according to the World Economic Forum's Global Gender Gap Report (2013), 125 among 136 countries. In the 1990s, following the implementation of the Economic Reform and Structural Adjustment Program, Egypt experienced growing gender gaps, partly because of the contraction of opportunities in the public sector, without an increase in available jobs in the non-governmental sectors (Assaad and Arntz, 2005).

In this paper, we provide an empirical analysis of how the important and recent political changes in the Arab World are shaping the gender gap in labor market outcomes. To construct a measure of intensity of the Egyptian protests, we exploit unique information on the number of demonstrators who died during the protests, denoted as "martyrs" in our data source (Statistical Database of the Egyptian Revolution) ${ }^{1}$. We also use information on labor market outcomes before and during the political unrest, from two waves (2006 and 2012) of the Egypt Labor Market Panel Survey (ELMPS). The panel structure of the data allows us to condition on unobserved heterogeneity.

Why do we expect the Arab Spring to change the relative position of women in the labor market? There are several potential mechanisms through which the Egyptian protests may affect women's labor market conditions. A first channel - which is the most plausible - is related to the idea that political instability may negatively affect growth (see Alesina, Özler, Roubini and Swagel, 1996). If political turnover represents at least in the short run a negative income shock, then for households that are close to the subsistence level, the negative shock would probably undermine the importance of cultural factors and attitudes towards female work (i.e., in periods of recession, the work of women might be encouraged if the households are close to the subsistence level, even if in normal economic conditions the labor market is highly segregated by gender). This is also in line with work of Attanasio, Low and SánchezMarcos (2005), who explore the role of female labor supply as an insurance mechanism against idiosyncratic earnings risk within the family. Were the households close to the subsistence level before the beginning of the political unrest? Campante and Chor (2012a) present the results of a poll conducted by the International Republican Institute in Egypt shortly after the resignation of Hosni Mubarak: 64 percent of respondents who claimed that they had taken part in the recent protests cited "low living standards/lack of jobs" as their main motivation and 41 percent of the respondents answered that they had "trouble feeding [themselves] and [their] family and

\footnotetext{
${ }^{1}$ See also the international press, for instance New York Times (2011), BBC News (2012) and Al Jazeera (2013).
} 
buying even the most essential things for survival” (see International Republican Institute, 2011 and Campante and Chor, 2012a for more results of this poll).

A second channel relates to one of the main determinants of the protests: the increase in the unemployment of educated youth (see Campante and Chor, 2012a), which may imply a change in the importance of human capital in the economy. Related to this point, Doepke and Tertilt (2009) show that theoretically, when the importance of human capital in the economy increases - for instance as a consequence of technological progress -, men might be willing to give more rights to women to ensure that their children's level of education is higher. In the context of the Arab World - which is very different from the context that motivates the analysis of Doepke and Tertilt (2009) - there is evidence of a deterioration of the importance of human capital and, for Egypt, a decline in social mobility among educated youth, which started in the mid-1980s and is linked to a contraction in public sector employment (Binzel and Carvalho, 2013). This decrease in the importance of human capital might imply a larger gender gap if men consider their children's level of schooling less relevant and are consequently less likely to support women's empowerment.

A third channel might go through migration. Herbst (1990) highlights how in most areas in Africa, in the beginning of the $20^{\text {th }}$ century, migration was the easiest option to express discontent with deteriorating economic and political conditions. Migration might influence the relative position of women in the labor market, for several reasons: having a household member who resides in another country is associated with changes in the household size (Gibson, McKenzie and Stillman, 2011), in the relative number of women and men within a household, in foregone earnings of the family members who emigrated, and in the amount of remittances received by the members who are left behind (Sjaastad, 1962). There is literature showing a negative effect of male migration on labor force participation of women left behind (see Lokshin and Glinskaya, 2009, among others).

A fourth channel goes through fertility behavior. The Egyptian protests may be an important source of uncertainty, and this uncertainty can affect the choice of whether or not to have a child (see Adsera, 2004, for a discussion on fertility choices and general uncertainty). Given that labor market and fertility choices are jointly determined, the uprisings could theoretically impact female labor market conditions through this channel.

A fifth channel concerns the possibility that in periods of recession, firms prefer to hire workers who are relatively less expensive, for instance women and minority groups (see, among others, Rubery, 1988). If this positive discrimination towards women was the main channel driving the relationship of interest, then this reason would predict a reduction in the gender gap in employment following a period of uprisings and political instability.

A sixth channel may refer to time constraints. If men are more likely than women to participate in protests, then we expect this participation to negatively affect the time they can allocate to work. This is another mechanism that may increase the labor force participation of women relative to men.

Finally, political unrest might change women's labor supply through changes in religious participation. For instance, Binzel and Carvalho (2013) present religion theoretically as a coping mechanism for unfulfilled aspirations and show how an unexpected decline in social mobility combined with inequality can produce a religious revival led by the educated middle class. Using data on the 1997 and 1998 Indonesian financial crisis, Chen (2010) demonstrates a causal effect of economic distress on religious intensity, measured using information on Koran study and Islamic school attendance. Chaney (2013) uses centuries of Nile flood data and shows an increase in the political power of religious leaders during periods of economic downturn. These three works thus confirm that political unrest and the business cycle may affect religious participation, which in turn can influence women's labor supply. This is in line 
with the literature showing the relationship between religion and religious rules, on the one hand, and gender inequalities in several outcomes of interest, on the other hand (see Becker and Woessmann, 2008; Meyersson, 2014; Noury and Speciale, 2014).

Our paper contributes to a growing literature on female labor force participation that documents significant persistence over time of women's labor supply. This inertia may depend on the nature of cultural beliefs and on historical determinants of social norms (see for instance, Alesina, Giuliano and Nunn, 2013). Despite this persistence, women's labor supply can react to technological, economic, demographic and political shocks: see Goldin and Katz (2002), Albanesi and Olivetti (2015) and Greenwood, Seshadri and Yorukoglu (2005) for an analysis of the consequences of technological and medical changes on female labor force participation; Fogli and Veldkamp (2011) and Ager, Brückner and Herz (2014) for the role of economic shocks; Teso (2014) and Grosjean and Khattar (2014) for the effects of demographic changes; Goldin (1991) and Acemoglu, Autor and Lyle (2004) for the role of World War II. From a conceptual point of view, in the presence of multiple labor market outcomes equilibria, these shocks may imply a shift from an equilibrium to another with a different level of women's labor supply.

We complement this literature by analyzing the effect of a recent and very relevant political shock, the Arab Spring protests, on the relative position of women in the labor market. While the available data on Egypt allows us to analyze the short-term labor market impacts only, the literature we cite above suggests how a relevant shock to the labor division between men and women may have long run consequences as cultural norms about the appropriate role of women vary. Related to this point, Goldin and Olivetti (2013) show that the shock associated to World War II had a persistent impact on labor market outcomes of higher educated women in the US. These findings are also consistent with a dynamic pattern proposed theoretically by Hazan and Maoz (2002). In their model, a woman's employment outside her home may initially have a direct negative effect on her household's utility, but an increase in women's labor force participation in a certain period decreases the utility loss for women who work outside the household in the following period. This brings a virtuous cycle of increases in women's labor force participation.

Our work also contributes to a growing literature on protests (see, among others, Kuran, 1989; Collins and Margo, 2007; Fearon, 2011; Campante and Chor, 2012a; Chaney, 2012; Madestam, Shoag, Veuger, and Yanagizawa-Drott, 2013; Campante and Chor, 2014; Kent and Phan, 2014; Aidt and Franck, 2015). Using data on the Arab Spring in Egypt, Acemoglu, Hassan and Tahoun (2014) investigate the effects of the recent protests on stock market returns, for firms connected to three groups: elites associated with Mubarak's National Democratic Party (NDP), the military, and the Islamist Muslim Brotherhood. They construct a daily estimate of the number of protesters in Tahrir Square as measure of revolution intensity, using information from Egyptian and international print and online media. With respect to this paper, our work differs in the outcome of interest (female labor market outcomes rather than firms' stock market returns) and in the way to construct the intensity of the protests. Our measure of intensity of the uprisings varies at the geographical level, while Acemoglu, Hassan and Tahoun (2014) focus on events in one location (Tahrir Square), exploiting variation at the daily level.

Our empirical strategy combines a Difference-in-Differences specification to an Instrumental Variable approach. We have information both before and after the uprisings, and exploit geographical differences in the protest intensity. To mitigate the potential endogeneity of our main explanatory variable, we use the distance to Cairo, Egypt's capital, as an instrument for the number of "martyrs" during the protests. We borrow this instrumental variable from the literature on civil conflicts (see, among others, Voors, Nillesen, Verwimp, Bulte, Lensink and Van Soest, 2012). Our first stage regressions - which show that our instrument is strongly 
negatively correlated with the intensity of the protests - add to a growing literature recognizing that political participation is spatially or geographically clustered (Mutz, 2002; McClurg, 2003; Cho and Rudolph, 2008). Our identifying assumption is that the distance to the capital does not explain labor market outcomes after we condition on several other mechanisms different from the protests: the governorate-level share of public sector employment, number of police stations, average level of education, a dummy variable for fully urban governorates, GDP per capita and population density. The advantage of combining an Instrumental Variable approach with the Difference-in-Differences methodology is that our estimates remain unbiased in case of omission of differences that remain the same over time, across governorates with different levels of protest intensity.

Our estimates show that women's labor force participation in the aftermath of the 2011 Egyptian protests has increased, especially for those households belonging to the lowest two quartiles of the pre-revolution distribution of income per capita. This increase in labor force participation is mainly explained by an increase in women's unemployment and private sector employment. Our results suggest that the recent waves of protests have reduced the number of weekly working hours for men and increased the volatility of their income. These findings may be compatible with a framework of intra-household risk sharing where women tend to increase their labor force participation to face the increased risk and instability of men's income flows.

We also find a reduction in migration in the aftermath of the revolution. Even if this may be compatible with an increase in labor force participation for women left behind, the magnitude of this effect is not large enough to justify the size of the adjustment in labor market outcomes. Instead we do not find statistically significant evidence for the other mechanisms: remittance transfers, fertility decisions, schooling decisions for children and religious education. Our analysis also suggests that neither discrimination nor time constraints are driving the relationship of interest.

The rest of this paper is organized as follows. Section 2 presents information on the Egyptian revolution and "martyrs." Section 3 provides a description of the data. Section 4 describes the empirical strategy. Section 5 presents the results and discusses the mechanisms. Section 6 provides some robustness checks. Section 7 briefly concludes.

\section{Background Information: The Egyptian Revolution and the "Martyrs"}

The first wave of the Egyptian revolution began on the 25th of January 2011. Youth activists, workers and football fans rallied against Mubarak's government, participating in a protest that represents one of the biggest revolutionary movements in recent years (The Guardian, 2011). The Egyptian revolution was a people-led political mobilization, positioned among a series of Arab Spring uprisings that started in Tunisia and rapidly spread to the Middle East. Protests in Egypt unfolded in the country's two major cities - Cairo and Alexandria - with millions rushing to the streets a few days after the first protest (Beissinger, Jamal, and Mazur, 2012). Crowds filled Tahrir, or Liberation, Square, and spilled into nearby streets. Protestors also came from rural provinces in the Nile Delta (CNN, 2011).

Demonstrators were taking to the streets in several countries in the Arab World to protest against their respective authoritarian regimes. After few weeks of mass demonstrations, Ben Ali in Tunisia and Mubarak in Egypt were forced to resign, putting an end to two longstanding autocratic regimes in the region. Inspired by the Tunisian and Egyptian uprisings, several Arab countries - Jordan, Bahrain, Libya, Syria, Iraq, Lebanon, Morocco and Saudi Arabia witnessed similar revolutionary movements with varying levels of intensity (Beissinger, Jamal, and Mazur, 2012; Moaddel, 2012).

Egyptian protestors tended to be overwhelming male, middle class, with above average educational levels, drawn from middle occupational and income profiles, and heavily 
networked. More precisely, according to the Arab Barometer Study conducted in Egypt in July 2011, 77\% of demonstrators were male, $46 \%$ had the highest level of education (university and above) and $49 \%$ were internet users as opposed to only $18 \%$ for the population as a whole. These revolutionaries were motivated primarily by economic reasons and to a lesser extent by political and civil freedoms (Beissinger, Jamal, and Mazur, 2012).

The spark that ignited the Egyptian revolution was mainly the death of a 28 years old man, called Khalid Said, who died after an encounter with the Egyptian police in Alexandria (New York Times, 2010). Shortly after his death, his story was spread all over blogs, websites and social media, evidencing the major role played by internet as a medium of communication and coordination tool used by protestors during the revolution (Beissinger, Jamal, and Mazur, 2012; Moaddel, 2012). The public protests started in the aftermath of Khalid Said's murder in Egypt's streets, where people were holding posters and banners with his photographs. These events built up to trigger the Egyptian revolution in January 2011 (Buckner and Khatib, 2014).

Many more Egyptian demonstrators died during the protests. These "martyrs" - a term used in the international press (see, for instance, New York Times, 2011, BBC News, 2012 and Al Jazeera, 2013) and in our data source - played a central role and were an indisputable catalyst in the onset of the Egyptian revolution, invoking moral outrage and creating a self-fulfilling movement of mobilization against the government. This is similar to what happened in Tunisia and Syria, with Mohamed Bouazizi and Hamza Al-Khatib being examples of demonstrators who died during the protests, and whose deaths became a catalyst for the revolution in their countries (Buckner and Khatib, 2014).

This portrayal of the "martyrs" in the Arab Spring uprisings is very different from the standard definition of martyrs who self-sacrifice themselves for their religious beliefs and faith. As Buckner and Khatib (2014) argument, in the context of the Arab Spring the term "martyr" has been attached to those who died at the hands of their own states in pursuit of political change.

In the immediate aftermath of Mubarak's resignation, as the Supreme Council of the Armed Forces (SCAF) took power in Egypt, a constitutional review committee was formed to formulate new amendments to the Constitution. The constitutional declaration of 2011 was approved on March 19 by referendum (Human Rights Watch, 2011). The transitional context dictated these new amendments: a term limit for future presidents, the separation of powers and a call for judicial oversight of elections, stood as paramount. Under the transitional government, the issue of women's rights was not a priority (Human Rights Watch, 2011; Gómez-Rivas, 2011). Women were officially excluded from the official committee proposing the amendments to the Constitution and their political representation in the aftermath of the revolution also remained very low (Human Rights Watch, 2011). The Provisional Constitution adopted in March 2011 governed Egypt until the adoption of a new Constitution in December 2012, under President Mohamed Morsi's rule.

\subsection{Stylized facts on the intensity of the revolution}

Protestors engaging in a revolutionary movement are not only committed in terms of time and resources, but they also acknowledge the probability of occurrence of certain risks, including arrest, injury or even death (Moaddel, 2012). Hence, the number of "martyrs" (i.e., demonstrators who died during the protests), using the terminology in our data source represents a central measure of the intensity of the protests and is quite correlated with a number of other indicators of the revolution.

Figure 1 displays the number of "martyrs" and injured from February 2011, after Mubarak stepped down and the Supreme Council of the Armed Forces (SCAF) took power in Egypt in the name of the military on the $11^{\text {th }}$ of February 2011, till June 2013, the end of former president Mohamed Morsi's one year rule. The number of arrested is also displayed during Mohamed 
Morsi's rule, from July 2012 till June 2013. As shown, these measures of the intensity of the violent protests are closely correlated and follow the same patterns. The first sharp trend shift in November 2011 corresponds to Mohamed Mahmoud Street's deadly clashes, which lasted five days, from the $19^{\text {th }}$ of November to the $24^{\text {th }}$ of November. It was a street massacre that broke out between protesters and Central Security Forces (CSF), as protests took place in Mohamed Mahmoud Street in response to a CSF's attack on a sit-in in Tahrir Square. The CSF dispersed demonstrators using birdshot, tear gas, rubber and live bullets. A concrete wall was installed in the street to prevent the protesters from reaching the Ministry of Interior building (Le Monde, 2011). The second sharp shift in February 2012 corresponds to a street battle between protesters and the police, near Egypt's Ministry of Interior, triggered by the deaths in Port Said Stadium riot, the country's worst soccer disaster. Demonstrators were condemning the death of soccer fans at the Port Said Stadium and were holding the military-led authorities accountable for the deaths (The Guardian, 2012). The trend shifts in November 2012 and January 2013 correspond to clashes between civilians and the police in the anniversaries of Mohamed Mahmoud Street's massacre and the $25^{\text {th }}$ of January revolution, respectively.

Figures 2, 3 and 4, display the geographical distribution of the "martyrs" from January 2011 to June 2012, the injured from February 2011 to June 2012 and the arrested from July 2013 to May $2014^{2}$. Cairo - in particular Tahrir Square - was the main center of mobilization of demonstrators and protesters during the first 18 days of the revolution and the second wave of the revolution. The figures show a greater number of "martyrs," injured and arrested in Cairo and its neighboring governorates. Our identification strategy is partly based on this stylized fact, as we discuss in Section 4.2.

\section{Data}

The empirical analysis relies on data from the Egypt Labor Market Panel Survey (ELMPS), a nationally representative panel survey. The ELMPS, as a typical labor force survey, covers topics such as employment, unemployment and earnings. Additionally, it provides very rich information on job dynamics, saving and borrowing behavior, migration, remittancerecipiency, parental background, education, entrepreneurial activities, fertility choices, women's status and decision-making (Assaad and Krafft, 2013).

The ELMPS is carried out by the Economic Research Forum (ERF) in cooperation with Egypt's Central Agency for Public Mobilization and Statistics (CAPMAS) since 1998. It has been administered to nationally representative samples in 1998, 2006 and $2012^{3}$. We take advantage of an important feature of the ELMPS, the fact of being carried out before and after the 2011 Egyptian protests. At the time of this writing, there is no available information on labor market outcomes after the revolution for the other countries that participated to the Arab Spring. We use the panel dimension and mainly focus on the 2006 and 2012 rounds, allowing us to observe individuals' labor market outcomes before and after the uprisings, as the fieldwork of the 2012 round took place from March 1, 2012 to June 10, 2012, more than a year after the protests. Of the 37,140 individuals interviewed in 2006, 28,679 individuals were successfully re-interviewed in 2012. We particularly focus on working-age individuals in the two-rounds, aged 15 to 64 years old. ${ }^{4}$ Descriptive statistics on individuals' and households' pre and post revolution characteristics are reported in Table 1.

\footnotetext{
${ }^{2}$ Online Appendix Table 9 presents the number of "martyrs” for the first eighteen days of the protests and for the subsequent period - from the $12^{\text {th }}$ of February 2011 till the end of June 2012.

${ }^{3}$ See Assaad and Barsoum (2000), Assaad (2002), Barsoum (2009) and Assaad (2009) for additional information on the survey.

${ }^{4}$ Individuals included in the estimation sample are at least aged 15 years old in 2006 and at most aged 64 years old in 2012. In the Online Appendix Table 16, we present a robustness check where we consider an estimation sample of prime-aged individuals (individuals aged at least 21 years old in 2006 to 64 years old in 2012).
} 
Given that we are matching households and individuals across survey rounds, two types of attrition can potentially arise: the first one is linked to the inability to track an entire household interviewed in 2006 while the second one is linked to the inability to track a split household (one or more individuals who left their original household either alone or with additional individuals who may have joined them later), when the original household can be tracked. Type- 1 attrition rates are $17.3 \%$ at the household level and $14.2 \%$ at the individual level, while type-2 attrition rate is $30.3 \%$. To correct for the possible biases that could result from these two types of attrition, we use panel weights between 2006 and $2012^{5}$.

One of the main novelties of this paper is the use of a unique dataset that to our knowledge has not been exploited in economic research yet: the Statistical Database of the Egyptian Revolution, administered by the Egyptian Center for Economic and Social Rights ${ }^{6}$. This dataset documents all the events, including fatalities, injuries, arrests and prosecutions during the period of the Egyptian revolution as a result of political and social changes. The data is collected during the first eighteen days of the protests (from the $25^{\text {th }}$ of January 2011 to the $11^{\text {th }}$ of February 2011), during the rule of the Supreme Council of the Armed Forces (SCAF) (from the $11^{\text {th }}$ of February 2011 to June 2012), during former president Mohamed Morsi's rule (from July 2012 till June 2013) and, lastly, most recent data cover the period from July 2013 to May 2014. These individual level data were collected on a daily basis. They document the names of the "martyrs," the injured and the arrested; their place of residence, occupation, marital status, date of birth; the type of incident leading to the death, injury or arrest; the governorate where the incident took place, as well as other relevant data for documentation purposes (see Online Appendix Figure 1 for a screenshot of these data).

Descriptive statistics for all outcome variables are provided for the estimation sample and by gender in Table 2. One important aspect is that female labor force participation is low in Egypt, around 30\% in 2006 for the working-age women in our sample. This reflects the fact that even though women have become much more educated over the past decades, relatively few engage in any kind of market work. In addition, the descriptive statistics show higher incidence of unemployment and non-wage work in 2006 among females compared to males. To a large extent, this segregation of the labor market by gender was due to the decline in government sector employment over the past two decades (Assaad and Barsoum, 2009). In line with the shrinking of the public sector, in 2006, women engage more in private sector employment compared to the public sector. Interestingly, women in our sample work in both formal and informal sectors, with similar incidences. By contrast, men seem to undertake more jobs in the informal sector compared to the formal sector. In terms of weekly working hours, conditional on being employed, Table 2 shows greater labor supply for men compared to women. However, it seems that between the two rounds of the survey, women who are employed tend to increase their labor supply, while men decrease the hours of work per week.

\section{Empirics}

\subsection{Empirical strategy and regression specification}

We investigate the impact of the 2011 protests on the relative position of women in the labor market by estimating the following Difference-in-Differences specification, where we allow gender to be an important dimension of heterogeneity of the treatment effect ${ }^{7}$ :

\footnotetext{
${ }^{5}$ See Assad and Krafft (2013) for a detailed discussion on sample attrition and the construction of the panel weights.

${ }^{6}$ The Center for Economic and Social Rights is a non-governmental organization that carries out research and advocacy projects on economic, social and cultural rights in several countries in the world, in collaboration with local human rights advocates and activists. It develops methodologies for measuring and monitoring economic and social rights compliance.

${ }^{7}$ We do not denote Equation 1 as a Difference-in-Difference-in-Differences specification, because we expect the protests to affect the labor market outcomes of men as well.
} 


$$
\begin{aligned}
& Y_{\text {igt }}=\alpha_{1} \text { martyrs }_{g} \times 2012_{t} \times \text { female }_{i}+\alpha_{2} \text { martyrs }_{g} \times 2012_{t} \\
& \quad+\alpha_{3} \text { martyrs }_{g} \times \text { female }_{i}+\alpha_{4} 2012_{t} \times \text { female }_{i}+\alpha_{5} \boldsymbol{X}_{i t}+\beta_{i}+\beta_{g} \\
& +2012_{t}+\varepsilon_{\text {igt }} .
\end{aligned}
$$

martyrs - our treatment variable - is a measure of the intensity of the protests: the governoratelevel number of "martyrs" from January 2011 to June 2012; 2012 is a dummy variable equal to 1 in 2012 (after the beginning of the protests), and 0 in 2006 (before the protests). To answer our research question, we compare outcomes of women with those of men, by including interaction terms with the female dummy variable. $\beta_{i}, \beta_{g}$ and $2012_{t}$ are respectively individual, district and year fixed effects. The two first fixed effects absorb the non-interacted terms female and martyrs.

The vector $X$ contains individual and household variables ${ }^{8}$. Individual controls include a dummy variable for ever-married status, three dummies for educational attainment: primary and preparatory education, secondary education either general or vocational and above secondary education, either post-secondary institute or university education and above. The reference category is no-educational degree either illiterate or literate without any diploma. Household controls include a rural dummy, an indicator for male headed households, a dummy variable for land ownership, household size, number of adults who are 15-64 years old, an indicator for the head's marital status being single and three dummies for the head of the household's educational attainment.

The coefficient of interest is the parameter $\alpha_{1}$ : it allows identifying the differential effect of the protests by gender (i.e., how the Arab Spring in Egypt affects the gender gap for several outcomes of interest. $\alpha_{2}$ quantifies the effect of the protests on men's labor market outcomes, while $\alpha_{1}+\alpha_{2}$ represents the effect on women's outcomes.

For each individual in the sample, we have information for two time periods, $t=2006$ and 2012. Taking the first difference of both left and right-hand side, we can transform Equation 1 as follows ${ }^{9}$ :

$\Delta Y_{i g}=\alpha_{1}$ martyrs $_{g} x$ female $_{i}+\alpha_{2}$ martyrs $_{g}+\alpha_{4}$ female $_{i}+\boldsymbol{\alpha}_{\mathbf{5}} \Delta \boldsymbol{X}_{\boldsymbol{i}}+\beta_{0}+u_{i g}$

The dependent variable in Equation 2 represents the change in an outcome of interest between 2012 and 2006. Similarly to Equation 1, the specification in Equation 2 allows to control for all time-invariant individual characteristics. While estimating the latter equation it is not possible to identify the coefficient $\alpha_{3}$, we can still estimate the coefficient of interest - $\alpha_{1}$ which is the parameter associated to the variable martyrs $s_{g} x 2012_{t} x$ female $_{i}$ in Equation 1 and to martyrs $_{g} x$ female $_{i}$ in Equation 2. $\beta_{0}$ is the constant term: it accounts for the average change in outcomes between the two waves of the survey across all individuals in the sample. Including $\beta_{0}$ is the equivalent of adding a year fixed effect in a regression where the dependent variables are expressed in levels ${ }^{10}$.

A potential threat to our identification strategy is that governorates exposed to a higher intensity of the protests may be on different economic trends, and hence would exhibit differential changes in labor market outcomes even in the absence of the uprisings. Online Appendix Table

\footnotetext{
${ }^{8}$ See Yang (2008) for an example of work that estimates, among other outcomes, labor supply equations conditioning on a similar set of variables. For sake of brevity, in the notation of Equations 1 and 2 we only include individual controls $\left(X_{i}\right)$, while in the regressions we also condition on household controls $\left(X_{j}\right)$ and pre-revolution governorate characteristics.

${ }^{9}$ The advantage of estimating Equation 2 is that it allows identifying the coefficient of interest $\alpha_{1}$, with a more parsimonious specification for the IV regressions, with two endogenous regressors rather than three. The Online Appendix Table 10 shows that results are similar when we estimate Equation 1 using OLS specification, for labor force participation, unemployment and employment. Because the time periods are 2 (2006 and 2012), the first-difference transformation does not create issues of serial correlation of the error term.

${ }^{10}$ In Equation 1, the year fixed effect is 2012.
} 
1 presents Egyptian governorates' characteristics by the intensity of the revolution. We check whether governorates with an above median number of "martyrs" differ along a number of prerevolution characteristics from governorates with a below median number of "martyrs." Governorates exposed to a higher intensity of protests have a higher share of public sector employment and are more likely to be urban, compared to governorates exposed to a lower intensity of protests. Apart from these two characteristics, the two groups do not have any significant differences along the other dimensions such as population density, real GDP per capita, the average number of years of schooling for the youth population and the number of police stations. In the regression analysis, we take into account these potential differences in governorates' characteristics by conditioning on these pre-revolution governorate controls ${ }^{11}$. More importantly, in Section 6 we present placebo estimations of Equation 2 as falsification test.

\subsection{IV approach}

Our empirical strategy (see Equation 1 and its first-differenced equivalent Equation 2) relies on Difference-in-Differences estimation, which we combine to an Instrumental Variable approach. The specification allows for heterogeneity of the treatment effects by gender. There are several reasons why in Equation 2 the intensity of the protests (and the interaction term martyrs $x$ female as well) is endogenous. First, the number of "martyrs" might provide a measure with error of the intensity of the uprisings, implying attenuation bias for the estimated coefficient of interest $\alpha_{1}$. Second, unobserved time-varying labor market shocks at the governorate-level might influence simultaneously individual labor market outcomes and the intensity of the protests, which was mainly driven by poor labor market prospects for the educated youth (Campante and Chor, 2012a). As a consequence of these time-varying and asymmetric economic shocks, governorates exposed to a higher intensity of the protests may be on different economic trends, and hence would exhibit differential changes in labor market outcomes even in the absence of the 2011 Egyptian uprisings.

To mitigate the potential endogeneity of the "intensity of the protests" variable, we use the distance to Cairo as an instrument for the number of "martyrs" during the protests. We borrow this instrumental variable from the literature on civil conflicts (see among others Voors, Nillesen, Verwimp, Bulte, Lensink and Van Soest, 2012). More precisely, we interact the distance to the capital with the female dummy variable, and use distance to Cairo and the interaction term distance to Cairo $x$ female as instruments for martyrs and martyrs $x$ female in Equation $2^{12}$. Cairo, and in particular its well-known Tahrir Square, was the main center of mobilization of demonstrators and protesters during the revolution. The closer to the capital, the greater was the mobilization and the higher was the probability of participation in demonstrations.

Apart from the role of individual-level characteristics, such as education, income, gender and civic associations' engagement (see Rosenstone and Hansen, 1993; Campante and Chor, 2012b), a growing literature recognizes that political participation is spatially or geographically clustered (Mutz, 2002; McClurg, 2003; Cho and Rudolph, 2008). Individuals are more likely to participate in political activities if people around them are likely to participate. The literature

\footnotetext{
${ }^{11}$ The inclusion of pre-treatment controls is a standard approach in the estimation of Difference-in-Differences specifications (see for instance Yang, 2008). In Online Appendix Table 2, we present coefficient estimates from a regression of the governorate level number of "martyrs" on a set of pre-revolution governorate characteristics. No coefficient is statistically different from zero. This suggests that governorates exposed to different intensities of the protests do not significantly differ from each other, along a set of pre-revolution governorate characteristics.

12 The outcomes of interest are either categorical or continuous variables. Some dependent variables take the values $-1,0,1$, from first differencing dummy variables like labor force participation, employment and unemployment. For these categorical variables, we have also tried to estimate Equation (2) using IV Ordered Probit model by fitting an observed recursive mixed process model (using the cmp command in STATA, which was developed by Roodman, 2011). Results from this check are consistent with the 2SLS estimates (see Online Appendix Table 11).
} 
provides various explanations and channels underlying these effects but, despite the growing recognition of the hypothesis of spatial clustering, lacks consensus regarding the specific mechanism operating. Cho and Rudolph (2008) suggest four alternative theoretical mechanisms to explain the geographical clustering of political participation: self-selection, elite-driven processes, social interaction and casual observation. The first channel relates to the fact that people make residential choices based on individual-level criteria. Because similar like-minded individuals choose to live next to each other, the spatial clustering of political participation may be a result of selection. The second mechanism suggests that political elites target certain geographical regions to mobilize the mass. Accordingly, elite-driven mobilization processes can explain the observed spatial patterns. The third channel operates through social interactions. Individuals value political information that they seem to acquire through social networks and interactions within their social environment. Thus, as this social learning process diffuses, similar patterns of political engagement arise within an individual's social environment. The last mechanism operates through casual observation. According to Cho and Rudolph (2008), individuals detect signals about the prevailing norms and political preferences of the local community by observation. Consequently, spatial proximity may shape their political participation through this channel, even if all the contextual effects are controlled for.

Following these works, the distance to the capital Cairo is meant to capture the geographical/spatial clustering in political participation. Our identification strategy therefore relies on a theory of diffusion or contagion that begins at a core and spreads to neighboring areas. This approach perfectly fits the participation patterns of the demonstrations observed during the Egyptian revolution. Protests starting at a core, the capital Cairo, unfold and propagate gradually to the other governorates.

To provide additional evidence on the reason why our instrumental variable is correlated with the endogenous regressor, in Figure 5 we present a two-way scatter plot between the participation rates in the second round of the Presidential elections of June 2012 and the distance to the capital Cairo. The participation rates in the presidential elections are negatively correlated with the distance to Cairo. Similarly, our instrumental variable is negatively correlated with the political mobilization during the Arab Spring. Residents in Cairo and neighboring governorates are more likely to participate in the demonstrations and elections. For all IV specifications, we report the first stage Kleibergen-Paap rk Wald F-statistics, which show that in all instrumental variables regressions our instruments are well correlated with the endogenous regressors.

\subsubsection{Discussion on the validity of the instrument}

Our identifying assumption is that distance to the capital does not explain labor market outcomes after controlling for several other mechanisms different from the protests. To ensure that the distance to the capital only affects labor market outcomes through its impact on the political shock (and therefore to ensure that the exclusion restriction holds), we condition on several pre-revolution (2006) governorate characteristics. For instance, a potential threat to the validity of our instrumental variable strategy is that most public employment opportunities are in (or close to) Cairo. This may represent a problem because in Egypt the contraction in public sector employment over the past two decades is associated with the decline in social mobility among educated Egyptian youth (Binzel and Carvalho, 2013), and therefore is a potential determinant of our main explanatory variable (i.e., political unrest). To avoid that our IV findings are simply driven by distance to the capital proxying public sector employment opportunities, in some specifications we condition on the share of public sector employment in 2006 by governorate and its interaction term with the female dummy variable. 
Another potential concern of the IV strategy is that the capital represents the area with the highest number of police stations. This implies a higher probability for a protester to have a clash with the police. Moreover, the police stations might be located in areas where public sector employment opportunities are relatively higher. As additional control, in some regressions we include the number of police stations at the governorate level per 10,000 inhabitants and its interaction with female ${ }^{13}$.

The capital might as well attract the educated youth. As Lipset (1959) advocates, education is a key determinant of democratic values. In this context, the most educated people are likely to be more concerned about politics, have greater capabilities to understand societal issues and hence, be more likely to participate in protest activism. According to Inglehart (1990), the youth tend to hold more modern, democratic and universal worldviews. Therefore we have checked the robustness of our results to the addition of the average level of education for individuals aged 15 to 30 years old, by governorate and for the year 2006 (i.e., before the revolution), and its interaction term with female. This is important because the average education level of young people might simultaneously affect the intensity of the protests - most of the protesters being young and relatively well educated - and individual labor market outcomes, through human capital externalities and the association between average education and returns to human capital.

Distance to Cairo might as well capture the degree of centrality and closeness to the core of the Egyptian economy. This represents an additional potential threat to the validity of the instrumental variable because distance to the capital could therefore explain the overall labor market and population dynamics ${ }^{14}$. To address this potential issue, in some specifications we add as controls the log of GDP per capita in 2006, the total population density in 2006 and their interaction terms with female.

In addition, distance to Cairo might encompass rural and urban dynamics. Living in urban areas promotes political participation as it captures access to more resources and information compared to remote or rural areas (Moaddel, 1993). Therefore, in some specifications we also include a fully urban governorate dummy and its interaction term with female.

The inclusion of all the interaction terms we present above in this sub-section does not exclude, however, that other omitted factors can be correlated with both the intensity of the protests and labor market outcomes. The advantage of combining an Instrumental Variable approach with a Difference-in-Differences specification is that our estimates remain unbiased in case of omission of differences across governorates with different levels of protest intensity, provided that such differences remain the same over time. In Section 6, we present falsification tests confirming the validity of the parallel trends assumption, which is required for the Differencein-Differences methodology.

\subsubsection{First-stage regressions}

In Table 3, we report first stage regressions where we use the distance to Cairo (in hundreds of kilometers) and its interaction term with the female dummy to instrument the governorate level number of "martyrs" and its interaction term with the female dummy. In columns 1 and 2, we condition on individual and household characteristics, while in columns 3 and 4, we also include the pre-revolution governorate controls discussed earlier. As we might expect, the

\footnotetext{
${ }^{13}$ In Online Appendix Table 2, we find a negative correlation between the governorate level number of "martyrs" and the number of police stations per 10,000 inhabitants, even if this correlation is imprecisely estimated. This may suggest that the number of "martyrs" represents as well a proxy for the participation in demonstrations (the presence of police stations deterring the participation in protest activities) rather than just being a proxy for political repression.

${ }^{14}$ For instance, the distance to the capital might be correlated with social ties - people living in regions closer to Cairo being more likely to have closer social links to people in Cairo - and, through this channel, with regional economic development as well (see Burchardi and Hassan, 2013).
} 
distance to Cairo is highly correlated with the intensity of the protests, proxied by the governorate level number of "martyrs." The greater the distance to the capital, the less the number of "martyrs." Relying on the estimated coefficient in column 3, when we condition on individual, household and pre-revolution governorate controls, we find that an increase in the distance to Cairo by 100 kilometers reduces the number of "martyrs" by about 27 people ${ }^{15}$.

\section{Results}

\subsection{The impact of the Arab Spring protests on women's labor market outcomes}

Table 4 presents estimates of the effect of the protests on women's labor force participation, unemployment and employment. Our dependent variables are the changes in labor market outcomes between 2012 and 2006. We report both OLS and IV estimates, where we use the distance to the capital Cairo and its interaction term with the female dummy to instrument the governorate level number of "martyrs" and its interaction term with the female dummy. In some specifications, we only condition on individual and household controls. In other specifications, we also include the pre-revolution governorate controls discussed earlier ${ }^{16}$. The inclusion of pre-treatment control variables is a standard approach in the literature that estimates Difference-in-Differences equations.

Our preferred specifications are the IV regressions where we condition on individual, household and pre-revolution governorate controls. The two estimated coefficients of interest are the interaction term between the number of "martyrs" and the female dummy $\left(\alpha_{1}\right.$ in Equation 2), and the number of "martyrs" ( $\alpha_{2}$ in Equation 2). The former coefficient captures the differential effect of the protests on labor market outcomes of women relative to men (i.e., how the protests affect the gender gap in labor force participation, employment and unemployment). The latter coefficient provides an estimate of the effect of the protests on men's labor market outcomes.

In the IV specifications, the estimated coefficient on the interaction term between the female dummy and the number of "martyrs" is always positive and statistically different from zero. This finding implies that the protests are reducing the gender gap in labor force participation. Relative to men, women have become more likely to participate in the Egyptian labor market because of the 2011 protests. To quantify the effect of the uprisings on women's labor force participation, we sum the two estimated coefficients $\alpha_{1}$ and $\alpha_{2}$. If we consider a standard deviation (1.199) increase in the number of "martyrs," the revolution increases women's labor force participation by 13 percentage points $(1.199 *(-0.028+0.138)$, see column 4 of Table 4$)$. This finding is interesting since women's labor force participation in Egypt remains very low despite the substantial increase in their educational attainment (Binzel and Assaad, 2011). As Table 2 shows, women's labor force participation is strikingly lower than their male peers'. Focusing on our estimation sample, in 2006 women's labor force participation is only $29 \%$ as opposed to $81 \%$ for men's labor force participation. Therefore, in percent terms, the impact of the Arab Spring protests on women's labor force participation is large, about 45\% (13/29) of the 2006 mean value of this labor market outcome. Also, our results show that a standard deviation increase in the intensity of the protests has reduced about $31 \%$ of the gender gap in labor force participation (16 over 52 percentage points, where in the computation of the effect we use $1.199 * 0.138$ from column 4 of Table 4 and 0.52=0.811-0.293 from Table 2).

It is interesting to analyze whether the relative increase in women's labor force participation is due to a rise in employment or unemployment. We find that because of the protests, women's unemployment and employment both increase (see the test with null hypothesis $\alpha_{1}+\alpha_{2}=0$ in

\footnotetext{
${ }^{15}$ Both the distance to the capital Cairo and the governorate-level number of "martyrs" are multiplied by 100.

${ }^{16}$ In unreported regressions, we have included the pre-revolution governorate controls gradually, that is to each regression we have added each of these variables and their interaction terms with the female dummy one at a time. Results are qualitatively very similar.
} 
columns 8 and 12 of Table 4). Considering a standard deviation change in the number of "martyrs," the increases are about 5 and 8 percentage points, respectively $\left(1.199 *\left(\alpha_{1}+\alpha_{2}\right)\right) .{ }^{17}$ The protests have encouraged women to engage in the Egyptian labor market by actively searching for employment, providing a leeway to increase women's labor force participation, which has remained very low.

To further investigate the role of the protests in explaining changes in labor market outcomes, we look at the effects on private and public sector employment. This analysis is particularly interesting because a distinctive divide between public and private sectors characterizes the Egyptian labor market (El-Haddad, 2009). For many years, the public sector dominated employment in Egypt and was particularly targeted by women because of the shorter working hours and the lower effort requirements, giving women the opportunity to take care of domestic chores and home responsibilities. Following the public sector downsizing that started in the 1980s and the Economic Reform and Structural Adjustment Program implemented in Egypt in 1991, women witnessed a substantial reduction in the employment opportunities in the Egyptian labor market (Assaad and Arntz, 2005). Estimates in Table 5 show that a standard deviation increase in the intensity of the protests raises private sector employment of women by about 9 percentage points $(1.199 *(0.059+0.014))$. This is a sizable effect, given that the prerevolution mean value of this variable was 0.134 . However, the protests do not have a statistically significant effect on private sector employment of men and on public sector employment of both men and women.

In Online Appendix Table 3, we investigate the heterogeneity of the effects of the Egyptian uprisings on individuals' labor market outcomes, by sample distribution of pre-revolution per capita household income and individuals' educational attainment. The estimates show an increase in labor force participation for women who belong to the two lowest quartiles of the sample distribution of pre-revolution per capita household income (Panel A) and for women with secondary education (Panel B). In Online Appendix Table 4, we analyze the effects of the protests on labor market outcomes, by religious group. Results concerning Christian working aged individuals should be considered with caution because the sample size is small and for this estimation sample, the instruments are weakly correlated with the endogenous regressors. When we consider the subsample of Muslim individuals, an increase in the intensity of the protests raises women's labor force participation, unemployment and employment. The increase in employment is larger than the increase in unemployment.

\subsection{Mechanisms}

To explore the mechanisms through which the protests affect labor market outcomes, we first investigate their effect on monthly wages, hourly wages and the number of weekly working hours, conditional on employment (Table 6). Our estimates show that a standard deviation increase in the intensity of the protests has reduced men's weekly working hours by about 4 hours $\left(3.668^{*} 1.199\right)$. Instead, we do not find any statistically significant evidence of a negative effect of the 2011 protests on women's remuneration or weekly working hours (see the statistical tests with null hypothesis $\alpha_{1}+\alpha_{2}=0$ in Table 6).

To complement these findings, we have analyzed information from the 2012 wave of the ELMPS survey on whether individuals have witnessed any changes in employment conditions in the past three months due to the revolution. In line with our results, there are striking

\footnotetext{
${ }^{17}$ In Online Appendix Table 12, we have investigated the effect of the protests on a sample of couples only. To be included in the estimation sample of these regressions, the head of the household and his/her spouse need to be married in the two waves, 2006 and 2012, and need to be in the working age category (15-64 years old). The results on this subsample are consistent with our findings on the sample of all working age men and women. The protests increase women's participation by 11 percentage points, unemployment by 4 percentage points and employment by 7 percentage points, when these effects are computed considering an increase in the number of "martyrs" by 1 standard deviation. The sum $\alpha_{1}+\alpha_{2}$ is statistically significant for the 3 outcomes.
} 
differences when we compare the answers of men and women in our estimation sample: $55 \%$ of women report an improvement in working conditions compared to only $29 \%$ of men. In addition, in line with the findings presented earlier, $8 \%$ of men report a decrease in the number of working hours compared to only $1 \%$ of women, and $9 \%$ of men report a decrease in wages compared to $2 \%$ of women. Also, $16 \%$ of women report increases in pay or incentives as the change they witnessed in their job, while only $5 \%$ of men gave a similar answer. As Assaad and Krafft (2013) suggest, workers in the public sector were more likely to report improvements in working conditions, while workers in the private sector reported deterioration in working conditions ${ }^{18}$. The worsening of men's working conditions during the protests therefore also depends on their higher probability to be employed in the private sector.

We have also explored the role of income uncertainty (Table 7). Following Fuchs-Schündeln and Schündeln (2005), we use the logarithm of the variance of the logarithm of monthly wage as a risk measure ${ }^{19}$. We construct the income uncertainty variable using three definitions: the first definition is based on occupation, the second on occupation and education groups, while for the third we use information on occupation and gender ${ }^{20}$. Our regression analysis shows that the protests raise the variance of monthly wages for employed men by 3 to 6 percent, when we compute these effects considering a standard deviation increase in the value of "martyrs" $\left(0.029 * 1.199,0.041^{*} 1.199\right.$ and $0.028^{*} 1.196$, using the estimated coefficients reported in columns 2, 4 and 6, and which refer to $\alpha_{2}$ in Equation 2). Instead, the estimates show no negative effect on the variance of women's monthly wages, as we fail to reject the null hypothesis that the sum $\alpha_{1}+\alpha_{2}$ of the coefficients in the IV specifications is statistically different from zero. These findings are in line with the descriptive information of Assaad and Krafft (2013), who show that men have been increasingly employed in riskier and marginal forms of employment in the period from 2006 to 2012 compared to the period from 1998 to 2006. This substantial rise in irregular wage work is closely associated with poverty and vulnerability.

Overall, all these findings are compatible with a conceptual framework in which women are forced to participate in the labor market to compensate for falling male incomes or increased income uncertainty. ${ }^{21}$ This "added-worker effect" has been described in different contexts, see among others Lundberg (1985), Cullen and Gruber (2000), Hyslop (2001) and Stephens (2002). It is important to stress that women may react both to the expected and actual deterioration of their husband's earnings. The reaction to the expected deterioration can be inferred from a general decrease in men's wages, as the tables we describe above show. If many men witness a reduction in wages, then women may adjust their labor market decisions because of a reduction in their husbands' expected earnings. To show the reaction to the actual deterioration in husbands' labor market outcomes, we have analyzed the correlation between female labor force participation (dependent variable) and their husband's wage and its variance. Online

\footnotetext{
${ }^{18}$ To check whether people's perception matches the actual consequences of the revolution, Online Appendix Table 5 shows results from a regression in which the dependent variables are the same as in Table 6, and the main explanatory variable is an interaction term between the "martyrs" variable and a dummy equal to 1 if the individual is employed in the private sector. These regressions confirm a reduction in the number of hours worked per week for people working in the private sector (see test of statistical significance of the sum $\left.\alpha_{1}+\alpha_{2}\right)$.

${ }^{19}$ Fuchs-Schündeln and Schündeln (2005) compute this risk measure - the logarithm of the variance of the logarithm of income - for sixteen occupational and educational groups. They use three occupations (civil servants, white-collar workers and bluecollar workers) and five education levels (college, vocational training, intermediate/technical schooling, secondary schooling, and secondary schooling not completed). Cappellari and Jenkins (2014) use longitudinal data to construct an alternative measure of earnings' volatility, which is the standard deviation of the arc percentage change in earnings. Their approach is not adaptable in the case of two years panel data.

${ }^{20}$ Occupations are defined according to the ISCO-88 occupation classification (low-skilled blue collar, high-skilled blue collar, low skilled white collar and high-skilled white collar) for the longest job during past three months. Educational levels are the following: no educational degree, primary/preparatory education, secondary education and above secondary education.

${ }^{21}$ This channel is confirmed by the results in Online Appendix Table 3, showing that the revolution increases women's labor force participation in households close to the subsistence level and that belong to the two lowest quartiles of the pre-revolution per capita household income distribution.
} 
Appendix Table 6 presents OLS estimates where we condition on individual, household and pre-revolution governorate controls. While this table is merely descriptive, it remains informative if the assortative mating is positive (people marry with spouses having similar unobserved characteristics). This implies that the negative correlation coefficient on the husband's wage variable represents an upper bound of the true effect, and that the nonstatistically significance of the correlation between women's labor force participation and the variance of their husband's wage may simply be due to an upward bias of the OLS estimates: if we observe positive assortative mating and a lower level of dispersion in wages for men with higher levels of unobserved ability - which is plausible if talented men have more stable occupations - then the bias of the OLS coefficient of the variance of husband's wage is likely to be positive.

We have checked whether alternative mechanisms can explain our main findings. Table 8 presents results from OLS and IV regressions for the following outcomes at the household level: a dummy variable equal to 1 for households that report having a household member living or working abroad, log of remittances received, log of per capita household income (excluding remittances), log of per capita household income (including remittances), the ratio of pupils enrolled in religious (azhari) schools to the total number of individuals currently studying at the time of the survey (at the household level). Furthermore, we have investigated the effect of the protests on the probability of giving birth on a subsample of married women aged 18-49, nine months after the revolution compared to the same time interval before the 2006 survey. In the introduction, we have provided the theoretical rationale for investigating the effects of political unrest on these additional variables. We only focus on households that did not split and have the same structure between 2006 and 2012, to have comparable figures for our dependent variables.

Estimates in Table 8 show no effect of the protests on remittance-recipiency, household income (including or excluding remittances), religious education or women's fertility ${ }^{22}$. The only statistically significant result is a slight reduction in migration in the aftermath of the revolution, by about 1 percentage point when considering an increase in the number of "martyrs" by one standard deviation. ${ }^{23}$ This finding is in line with information from the Arab Barometer Study, which was conducted in Egypt in July 2011: 89\% of the Egyptians surveyed reported not considering migration, perhaps because of the optimistic expectations Egyptians had with respect to economic and political conditions. In principle, the reduction in migration we observe in Table 8 can increase women's labor force participation, as shown empirically in several studies (see, among others, Lokshin and Glinskaya, 2009). However, even if the estimates are statistically significant, the magnitude of the coefficient is not large enough to justify the size of the adjustment in women's labor force participation that we observe in Table 4.

We have checked whether participation in protests reduces the time individuals can allocate to work. If men are more likely than women to participate in the demonstrations (as is the case, see Section 2), then this time constraint mechanism can generate a reduction in the gender gap in labor force participation. As the descriptive statistics in Table 9 and Figure 6 show, $70 \%$ of the "martyrs" died on Friday and Saturday (i.e., in demonstrations that occurred during the

\footnotetext{
${ }^{22}$ In Online Appendix Table 13, we investigate the effect of the protests on women's decision-making relying on a wideranging set of questions asked to currently married women. Women are, in general, less likely to make decisions regarding making household purchases for daily needs, visits to family, friends and relatives, getting medical treatment or advice. They are also less likely to take children to the doctor and to send children to school on a daily basis. However, we find that women were more likely to deal with children's school and teachers, and to buy clothes and other needs for children. Overall, this table confirms that changes in social norms do not represent the main mechanism explaining the increase in female labor force participation.

${ }^{23}$ Since we rely on panel data from the 2006 and 2012 rounds of the ELMPS, we lose information on the 2012 refresher sample (2,000 households), which over-samples areas with high migration rates. See also Wahba (2014).
} 
weekend). This suggests that there was little substitution between protests and labor market activities ${ }^{24}$. To participate in the demonstrations, people tended to reduce their leisure activities more than their labor supply.

Discrimination cannot explain our findings either. When we consider results by educational attainment (Online Appendix Table 3), we find an increase in labor force participation after the revolution for women with primary and secondary education (for the former category the effect is less precisely estimated). From Online Appendix Table 7, we know that pre-revolution hourly wages of women with primary and secondary education are not below those of men with similar levels of education. Therefore the hypothesis of firms preferring to hire workers who are relatively less expensive does not seem to be the mechanism that increases women's private sector employment.

Finally, we have estimated the effects of the protests on children's education (see Online Appendix Table 8). In these regressions we consider as dependent variables a dummy equal to 1 if the child goes to school (0 otherwise) or a dummy equal to 1 if the child goes to religious school (0 otherwise). The IV coefficients of interest are never statistically significant, which suggests no effect of the protests on children's education.

To summarize the results of this section, the most plausible channel for the increase in women's labor force participation is a reduction in men's working hours as well as an increase in the uncertainty of their future income flows. This is explained by the fact that a large share of Egyptian men is employed in the private sector, which was the most affected sector during the Arab Spring. Women have increased their labor force participation to compensate for falling male incomes. The protests have also significantly reduced migration, but the small size of this effect cannot alone explain the large increase in women's labor force participation that followed the 2011 uprisings.

\section{Robustness Checks}

Our results are robust to several checks. In Table 10, rather than using the governorate-level number of "martyrs" (demonstrators who died during the protests) as a measure of the intensity of political unrest, we consider the number of injured (Panel A) and the number of arrested (Panel B). We find the same patterns we describe in Section 5.1. In Panel A, the interaction term between the number of injured and the female dummy is always positive and statistically different from zero. As expected, the order of magnitude of the estimated coefficients is smaller than in Section 5.1. The estimates provide confirmation of our results, namely a reduction in the gender gap in labor force participation (see the IV estimates of column 2). The sum of the two estimated coefficients $\alpha_{1}$ and $\alpha_{2}$ is statistically different from zero in columns 4 and 6 as well (see the test with null hypothesis $\alpha_{1}+\alpha_{2}=0$ ): an increase in the intensity of the protests measured using the information on the people injured raises both women's unemployment and employment. In Panel B, we consider the number of arrested by governorate to construct our measure of protests. The interaction term between the number of arrested and the female dummy remains positive and statistically different from zero when considering labor force participation and unemployment as dependent variables, while it is less precisely estimated when the left-hand side variable is employment.

In Table 11, we present additional robustness checks using the number of "martyrs" during the first eighteen days of the revolution (Panel A) and in the subsequent period, from the 12th of February 2011 till the end of June 2012, after Mubarak stepped down and the Supreme Council of the Armed Forces took power in Egypt in the name of the military (Panel B). In Panel C, we

\footnotetext{
${ }^{24}$ There was potential substitution between protests and labor market activities for people working on Fridays and Saturdays, for instance in restaurants, small shops, etc. Also, although the demonstrations may have taken place across the weekend, to some extent preparation (or recuperation) for (from) the protests might have interfered with some labor market activities during the weekdays as well.
} 
exclude from the estimation sample individuals residing in Cairo. Our results remain robust to these different checks. In Panels A and B, the interaction term between the numbers of "martyrs" and the female dummy is always positive and statistically different from zero in the IV estimates.

When eliminating the observations related to individuals residing in Cairo in Panel C, we find the same patterns described in Section 5.1. The order of magnitude of the estimated coefficients is larger. Results of this robustness check are extremely interesting for two reasons. First, given that most of the public employment opportunities are in the capital, the estimates in Panel C provide additional confirmation that the revolution also increases labor force participation through a rise in private sector employment (see in Table 11 the test with null hypothesis $\alpha_{1}+\alpha_{2}=0$, when the dependent variable is employment). Second, the exercise in Panel C provides additional evidence on the relevance of our instrumental variable and allows checking whether the results we find on labor market outcomes are only driven by the inclusion of Cairo. Interestingly, we find that our instrumental variable captures the spatial clustering effect of political participation, even after omitting Cairo: the distance to Cairo remains highly correlated with our endogenous variable - the governorate level number of "martyrs" - which proxies the intensity of the protests. The Kleibergen-Paap rk Wald F statistic shows that the instruments are strongly correlated with the endogenous regressors.

Our results are also robust when we use the number of male or female "martyrs" rather than the total number of demonstrators who died during the protests (see Online Appendix Table 14) and when we normalize our measure of revolution intensity by the population size (see Online Appendix Table 15).

In Table 12, we perform a falsification test of our identification strategy. To check the validity of the parallel trends assumption, we run a placebo Difference-in-Differences regression where we use information on labor market outcomes from the 1998 and 2006 ELMPS. Both these waves refer to a period before the beginning of the protests. In particular, our false experiment tests whether changes in individuals' labor market outcomes between 1998 and 2006 are associated with the subsequent 2011 protests ${ }^{25}$. Results from IV estimates are in Panel A, while findings that rely on the OLS estimator are in Panel B. The estimates confirm that no outcome was differentially changing for women before the revolution, in areas that had more protester deaths compared to those areas that had few deaths during the Arab Spring protests. We can infer that our results are not biased by pre-existing trends in labor market outcomes across individuals who reside in governorates exposed to different degrees of protest intensity. This check provides support to the validity of the parallel trends assumption, which is the main identifying hypothesis for Difference-in-Differences estimation.

\section{Concluding Remarks}

Did the Arab Spring protests affect the relative position of women in the labor market? We have answered this research question using data from Egypt and a unique dataset that provides information on the governorate-level number of demonstrators who died during the protests, denoted as "martyrs" in our data source (Statistical Database of the Egyptian Revolution). We have used the latter variable as a proxy for the intensity of political unrest.

Our estimates show that the 2011 Egyptian protests have reduced the gender gap in labor force participation, by increasing women's unemployment and private sector employment. The effects mainly concern households at the bottom of the pre-revolution income distribution. Our results also show that the protests have negatively affected men's working hours and have led to an increase in their income volatility. These changes have occurred because a large share of

\footnotetext{
${ }^{25}$ We track the same individuals we have in our estimation sample in the 1998 wave of the ELMPS and look at changes in labor market outcomes between 2006 and 1998, instead of changes between 2012 and 2006.
} 
Egyptian men are employed in the private sector, which has been the most affected sector during the Arab Spring protests. Since the most vulnerable households are more likely to bear the burden of men's increased income volatility induced by the revolution, women who belong to these poor households tend to increase their labor force participation as a household risk coping strategy.

Egyptian women's labor force participation has always remained very low compared to their male peers, even though women have become much more educated; a structural distortion acquiring the attention of scholars working on Egypt and the Middle East. Our results suggest that - at least in the short run - the 2011 protests have increased women's labor force participation in the Egyptian labor market. While the estimations show that the change in female labor supply was mainly due to necessity rather than a change in social norms - the latter mechanism being unreasonable to expect in the short term - a relevant shock to the labor division between women and men may well have long run consequences on the role of women in society. 


\section{References}

Acemoglu, A., Autor, D. H. and D. Lyle (2004). "Women, War, and Wages: The Effect of Female Labor Supply on the Wage Structure at Midcentury." Journal of Political Economy, vol. 112(3), pp. 497-551.

Acemoglu, D., Hassan, T. A. and A. Tahoun (2014) "The Power of the Street: Evidence from Egypt's Arab Spring". Mimeo.

Adsera, A. (2004). "Changing Fertility Rates in Developed Countries. The Impact of Labor Market Institutions", Journal of Population Economics, vol. 17, pp. 17-43.

Ager, P., Brückner, M. and B. Herz (2014). "Effects of Agricultural Productivity Shocks on Female Labor Supply: Evidence from the Boll Weevil Plague in the US South", EHES Working Papers in Economic History, n. 68

Aidt, T. S. and R. Franck (2015). "Democratization under the threat of revolution: Evidence from the Great Reform Act of 1832" Econometrica, vol. 83(2), pp. 505-47.

Albanesi, S. and C. Olivetti (2015). "Gender Roles and Medical Progress", Journal of Political Economy, forthcoming.

Alesina, A., Giuliano, P. and N. Nunn (2013). "On the Origins of Gender Roles: Women and the Plough", Quarterly Journal of Economics, vol. 128(2), pp. 469-530.

Alesina, A., Özler, S., Roubini, N. and Swagel, P. (1996). "Political Instability and Economic Growth", Journal of Economic Growth, vol. 1, pp. 189-211.

Al Jazeera (2013). "What did the 'revolutionary martyrs' die for?", 2 August 2013.

Assaad, R. (2002). "The Egyptian labor market in an era of reform", American University in Cairo Press, Cairo, Egypt.

Assaad, R. (2008). "Unemployment and Youth Insertion in the Labor Market in Egypt.” In The Egyptian economy: Current challenges and future prospects. Ed. Hana Khayr al-Din, pp. 133-178. Cairo: American University in Cairo Press.

Assaad, R. (2009). "The Egyptian labor market revisited", American University in Cairo Press, Cairo, Egypt.

Assaad, R. and Arntz, M. (2005). "Constrained geographical mobility abd gendered labor market outcoles under structural adjustment: Evidence from Egypt", World Development, vol.33, pp.431-454.

Assaad, R. and Barsoum, G. (2000). "Egypt Labor Market Survey, 1998: Report on the data collection and preparation"

http://www.erf.org.eg/CMS/uploads/pdf/1194970697_ELMS_98_Data_Report.pdf

Assaad, R. and Krafft, C. (2013). "Comparisons between the Egyptian Labor Market Panel Survey, Egyptian Population Census, and Egyptian Labor Force Surveys", Mimeo.

Assaad, R. and Krafft, C. (2013). "The structure and evolution of employment in Egypt: 19982012", Mimeo.

Assaad, R., Krafft, C. and Yassine, C. (2013). "An analysis of sample attrition and the calculation of sample weights in the Egypt Labor Market Panel Survey 2012", Mimeo.

Attanasio, O., Low, H. and Sánchez Marcos, V. (2005). "Female Labor Supply as Insurance Against Idiosyncratic Risk", Journal of the European Economic Association, vol. 3 (2-3): pp. 755-764. 
Bandiera, O., Buehren, N., Burgess, R., Goldstein, M., Gulesci, S., Rasul, I. and Sulaiman, M. (2014). "Women's Empowerment in Action: Evidence from a Randomized Control Trial in Africa", Mimeo.

Barsoum, G. (2009). "Methodological appendix 1: The Egypt Labor Market Panel Survey 2006: Documentation of the data collection process. In The Egyptian labor market revisited", ed. R. Assaad, 259-84. Cairo, Egypt: American University in Cairo Press.

BBC News (2012). "Egypt's revolution: 18 days in Tahrir Square", 25 January 2012.

Beaman, L., Duflo, E., Pande, R. and Topalova, P. (2012). "Female Leadership Raises Aspirations and Educational Attainment for Girls: A Policy Experiment in India", Science, vol. 335 (6068), pp. 582-586.

Beath, A., Christia, F. and Enikopolov, R. (2013). "Empowering Women through Development Aid: Evidence from a Field Experiment in Afghanistan", American Political Science Review, vol. 107 (3), pp. 540-557.

Becker, S. O. and L. Woessmann (2008). "Luther and the Girls: Religious Denomination and the Female Education Gap in Nineteenth-century Prussia", Scandinavian Journal of Economics, vol. 110 (4), pp. 777-805.

Beissinger, M., Jamal, A. and Mazur, K. (2012). "Who participates in democratic Revolutions? A comparison of the Egyptian and Tunisian Revolutions", Mimeo.

Binzel, C. and Assaad, R. (2011). "Egyptian Men working abroad : Labour supply responses by the women left behind", Labour Economics, vol. 18(S1), pp. 98-114.

Binzel, C., and Carvalho, J-P. (2013). "Education, Social Mobility and Religious Movements: A Theory of the Islamic Revival in Egypt", Mimeo.

Buckner, E. and Khatib, L. (2014). "The Martyrs' revolution: The Role of Martyrs in the Arab Spring", The British Journal of Middle East Studies, vol. 11(4), pp. 421-433.

Burchardi, K. B. and Hassan, T.A. (2013). "The Economic Impact of Social Ties: Evidence from German Reunification", The Quarterly Journal of Economics, vol. 128(3), pp. 12191271.

Campante, F. R. and Chor, D. (2012a). "Why was the Arab World poised for revolution? Schooling, Economic Opportunities and the Arab Spring", The Journal of Economic Perspectives, vol. 26(2), pp. 167-188.

Campante, F. R. and Chor, D. (2012b). "Schooling, Political Participation, and the Economy", Review of Economics and Statistics, vol. 94(4), pp. 841-859.

Campante, F. R. and Chor, D. (2014). "The People Want the Fall of the Regime: Schooling, Political Protest, and the Economy", Journal of Comparative Economics, vol. 42(3), pp. 495-517.

Cappellari, L. and Jenkins, S. P. (2014). "Earnings and labour market volatility in Britain, with a transatlantic comparison", Labour Economics, vol. 30, pp. 201-211.

Chaney, E. (2012). "Democratic Change in the Arab World, Past and Present", Brookings Papers on Economic Activity, vol. 42(1), pp. 363-414.

Chaney, E. (2013). "Revolt on the Nile: economic shocks, religion, and political power", Econometrica, vol. 81(5), pp. 2033-2053.

Chen, D. L. (2010). "Club Goods and Group Identity: Evidence from Islamic Resurgence during the Indonesian Financial Crisis", Journal of Political Economy, vol. 118(2), pp. 300-354. 
Cho, W.T. and Rudolph, T. (2008). "Emanating political participation: untangling the spatial structure behind participation", British Journal of Political Science, vol. 38(2), pp. 273289.

CNN News. (2011). "Anti-Mubarak protests surge, but remain peaceful", February, 1, 2011.

Collins, W. J. and Margo, R. A. (2007). "The economic aftermath of the 1960s riots in American cities: Evidence from property values", Journal of Economic History, vol. 67(4), pp. 849-883.

Cullen, J. and Gruber, J. (2000). "Does unemployment insurance crowd out spousal labor supply? ", Journal of Labor Economics 18(3), pp. 546-572.

Diebolt, C. and Perrin, F. (2013) "From Stagnation to Sustained Growth: The Role of Female Empowerment" American Economic Review, 103(3), pp. 545-49.

Doepke, M. and Tertilt, M. (2009). "Women's Liberation: What's in It for Men? ", Quarterly Journal of Economics, pp. 1541-1591.

Duflo, E. (2012). "Women Empowerment and Economic Development", Journal of Economic Literature, vol. 50(4), pp. 1051-1079.

Duflo, E., Dupas, P. and Kremer, M. (2014). "Education, HIV, and Early Fertility: Experimental Evidence from Kenya", American Economic Review, forthcoming.

El-Haddad, A. (2009). "Labor Market Gender Discrimination under Structural Adjustment: The Case of Egypt", Mimeo.

El Mahdi, A. (2000). "The Labor Absorption Capacity in the Informal Sector in Egypt", in Assaad, R. (ed.), The labor market in a reforming economy: Egypt in the 1990s, Ch.3, Cairo; The American University Press, 2002.

Fearon, J. D. (2011). "Self-Enforcing Democracy", Quarterly Journal of Economics 126, pp. 1661-1708.

Fogli, A. and L. Veldkamp (2011). "Nature or Nurture? Learning and the geography of female labor force participation", Econometrica, vol. 79(4), pp. 1103-1138.

Fuchs-Schündeln, N. and Schündeln, M. (2005). "Precautionary Saving and Self-Selection: Evidence from the German Reunification Experiment", Quarterly Journal of Economics, vol. 103 (5).

Gibson, J., McKenzie, D. and Stillman, S. (2011). "The Impacts of International Migration on Remaining Household Members: Omnibus Results from a Migration Lottery Program", The Review of Economics and Statistics, MIT Press, vol. 93(4), pp. 1297-1318.

Goldin, C. (1991). "The Role of World War II in the Rise of Women's Employment", American Economic Reviev, vol. 81(4), pp. 741-756.

Goldin, C. and L. F. Katz (2002). "The Power of the Pill: Oral Contraceptives and Women's Career and Marriage Decisions", Journal of Political Economy, vol. 110(4), pp. 730-770.

Goldin, C. and C. Olivetti (2013). "Shocking Labor Supply: A Reassessment of the Role of World War II on Women's Labor Supply", American Economic Review: Papers \& Proceedings, vol. 103(3), pp. 257-262.

Gómez-Rivas, C. (2011). "Women, Shari'a, and Personal Status Law Reform in Egypt after the Revolution", Middle East Institute, October, 1, 2011.

Greenwood, J., Seshadri, A. and M. Yorukoglu (2005). "Engines of Liberation", Review of Economic Studies, vol. 72, pp. 109-133. 
Grosjean, P. and R. Khattar (2014). "It’s Raining Men! Hallelujah?", mimeo.

Hazan, M. and Y. D. Maoz (2002). "Women's labor force participation and the dynamics of tradition", Economics Letters, vol. 75, pp. 193-198.

Herbst, J. (1990). "Migration, the politics of protest and state consolidation in Africa" African Affairs, Vol. 89, No. 355, pp. 183-203.

Human Rights Watch (2011). "Egypt: Ensure Women Equal Role in Elections, Reform", March, 28, 2011.

Hyslop, D. R. (2001). "Rising U.S. Earnings Inequality and Family Labor Supply: The Covariance Structure of Intrafamily Earnings", American Economic Review, vol. 91(4): pp. 755-777.

Inglehart, R. (1990). "Culture Shift in Advanced Industrial Society", Princeton, N.J: Princeton University Press.

International Republican Institute (2011). "Egyptian Public Opinion Survey", April 14-April 27, 2011.

Jensen, R. (2012). "Do Labor Market Opportunities Affect Young Women's Work and Family Decisions? Experimental Evidence from India", Quarterly Journal of Economics, vol. 127(2), pp. 753-792.

Kent, L. and Phan, T. (2014). "Protest and Repression: a Model of the Arab Spring", mimeo.

Kuran, T. (1989). "Sparks and prairie fires: A theory of unanticipated political revolution", Public Choice vol. 61 (1), pp. 41-74.

Le Monde. (2001). "La bataille de la Rue Mohamed Mahmoud", November 22, 2011.

Lipset, S. (1959). "Some Social Requisites of Democracy: Economic Development and Political Legitimacy" The American Political Science Review, vol. 53(1), pp. 69-105.

Lokshin, M. and E. Glinskaya (2009). "The Effect of Male Migration on Employment Patterns of Women in Nepal", World Bank Economic Review, vol. 23(3), pp. 481-507.

Lundberg, S. (1985). "The Added Worker Effect", Journal of Labor Economics, volume 3(1): pp. 11-37.

Madestam, A., D. Shoag, S. Veuger, and D. Yanagizawa-Drott (2013). "Do political protests matter? Evidence from the tea party movement", Quarterly Journal of Economics, 128(4), pp. 1633-1685.

McClurg, S. C. (2003). "Social Networks and Political Participation: The role of social interaction in explaining political participation", Political Research Quarterly, vol. 56, pp. 449-464.

Meyersson, E. (2014) "Islamic Rule and the Empowerment of the Poor and Pious", Econometrica, vol. 82(1), pp. 229-269.

Minnesota Population Center (2011). Integrated Public Use Microdata Series, International: Version 6.1. University of Minnesota, Minneapolis.

Mutz, D. (2006). "The Consequences of Cross-cutting Networks for Political Participation", American Journal of Political Science, vol. 46, pp. 838-855.

Moaddel, M. (1993). "Class, Politics, and Ideology in the Iranian Revolution" New York: Columbia University Press. 
Moaddel, M. (2012). "The Arab Spring and Egyptian Revolution Makers: Predictors of Participation", Population Studies Center Research Report, No. 12-775.

New York Times (2011). "Egypt Erupts in Jubilation as Mubarak Steps Down", February 11, 2011.

Noury, A. and B. Speciale (2014). "Social Constraints and Women's Education: Evidence from Afghanistan under Radical Religious Rule", Mimeo.

Roodman, D. (2011) "Fitting fully observed recursive mixed-process models with cmp," Stata Journal vol. 11(2), pp. 159-206.

Rosenstone, S. J. and Hansen, M. (1993). "Mobilization, Participation and Democracy in America", New York: Macmillan.

Rubery, J. (ed.) (1988). "Women and Recession", London and New York: Routledge and Kegan Paul.

Said, M. (2007) “The fall and rise of earnings and inequality in Egypt: New evidence from the ELMPS 2006”. ERF working paper No. 0708.

Sjaastad, L. A. (1962). "The costs and returns of human migration", Journal of Political Economy, vol. 70, No. 5, Part 2: Investment in Human Beings, pp. 80-93.

Springborg, R. (2011). "The Political Economy of the Arab Spring", Mediterranean Politics, vol. 16(3), pp. 427-433.

Stephens, M. J. (2002). "Worker displacement and the added worker effect", Journal of Labor Economics, vol. 20(3), pp. 504-537.

Stewart, F. (1992). "Can adjustment program incorporate the interests of women?", In Afshar, H. and Dennis, C. (eds.), Women and adjustment policies in the Third World (pp. 13-45). New York: St-Martin's Press.

Teso, E. (2014) "The Long-Term Effect of Demographic Shocks on the Evolution of Gender Roles: Evidence from the Trans-Atlantic Slave Trade", mimeo.

The Guardian. (2011). "Egypt braced for 'day of revolution' protests", January 24, 2011.

The Guardian. (2012). "Egypt : Port Said Football disaster", February 2, 2012.

The New York Times. (2010). "Death in Police Encounter Stirs calls for change in Egypt", July 18, 2010.

United Nations (2005). "Progress towards the Millennium Development Goals, 1990-2005. Secretary-General's Millennium Development Goals Report", New York and Geneva: United Nations Publications.

United Nations (2013). "Social, economic and legal empowerment of Egyptian women", Joint Programme proposal submitted by: United Nations Development Programme (UNDP).

Voors, M. J., Nillesen, E. E. M., Verwimp, P., Bulte, E. H., Lensink, R. and Van Soest, D. P. (2012). "Violent Conflict and Behavior: A Field Experiment in Burundi," American Economic Review, vol. 102(2), pp. 941-964.

Wahba, J. (2009). "Informality in Egypt: a stepping stone or a dead end? ", ERF Working Paper.

World Economic Forum. (2013). "Global Gender Gap Report 2013", Cologny/Geneva, Switzerland. 
Wahba, J. (2014). "Through the keyhole: International migration in Egypt", ERF Working Paper.

Yang, D. (2008) "International Migration, Remittances, and Household Investment: Evidence from Philippine Migrants’ Exchange Rate Shocks", Economic Journal, vol. 118, pp. 591630. 
Figure 1: The Numbers of "Martyrs", Injured and Arrested from February 2011 to June 2013

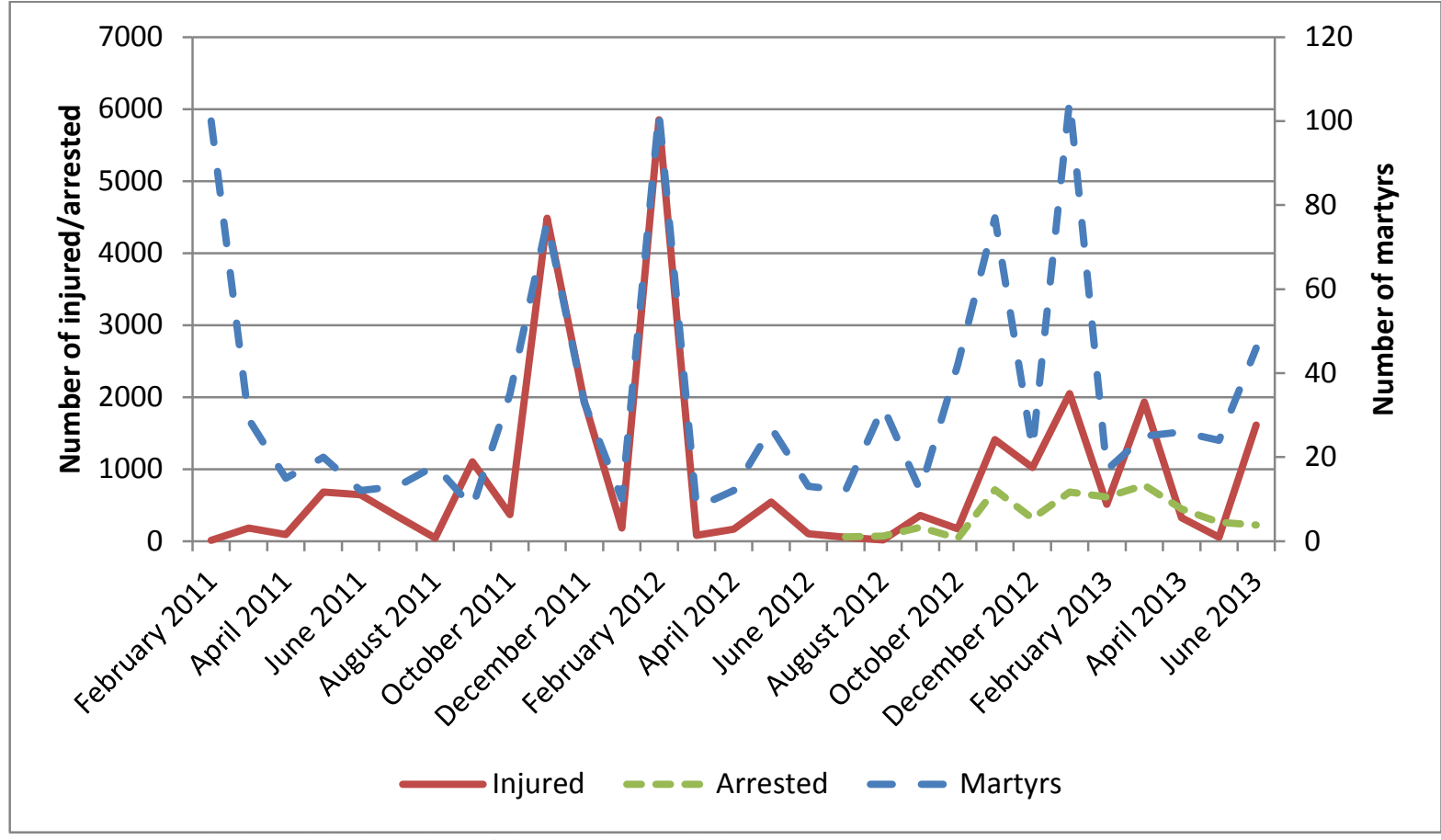

Notes: Data source is the Statistical Database of the Egyptian Revolution.

Figure 2: Geographical Distribution of “Martyrs” from January 2011 Till June 2012

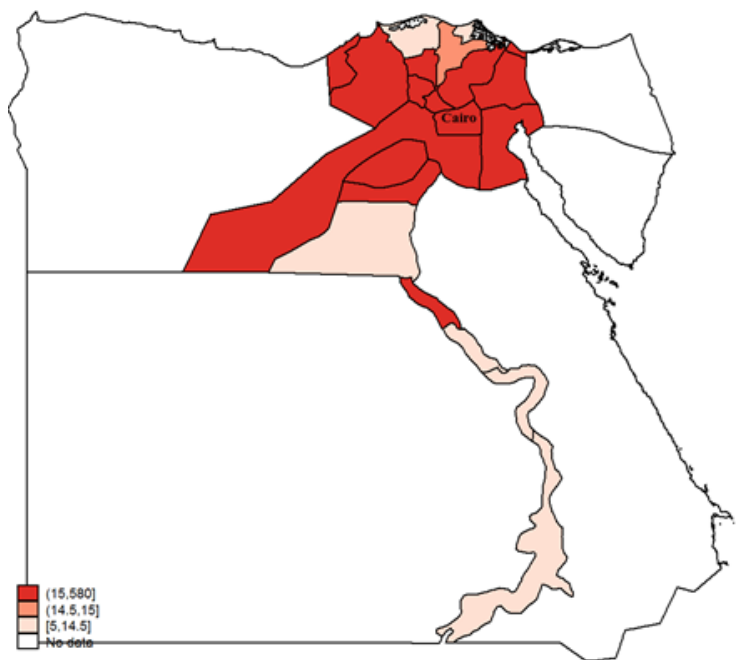

Notes: Data source is the Statistical Database of the Egyptian Revolution ${ }^{26}$.

\footnotetext{
${ }^{26}$ The five border governorates are Matruh, New Valley, Red Sea, North and South Sinai. They are not included in our sample since the Egypt Labor Market Panel Survey we are using in the empirical analysis does not cover them. According to Minnesota Population Center (2011), in 2006 no more than 2\% of the Egyptian population lived in these border governorates.
} 
Figure 3: Geographical Distribution of the Injured from February 2011 till June 2012

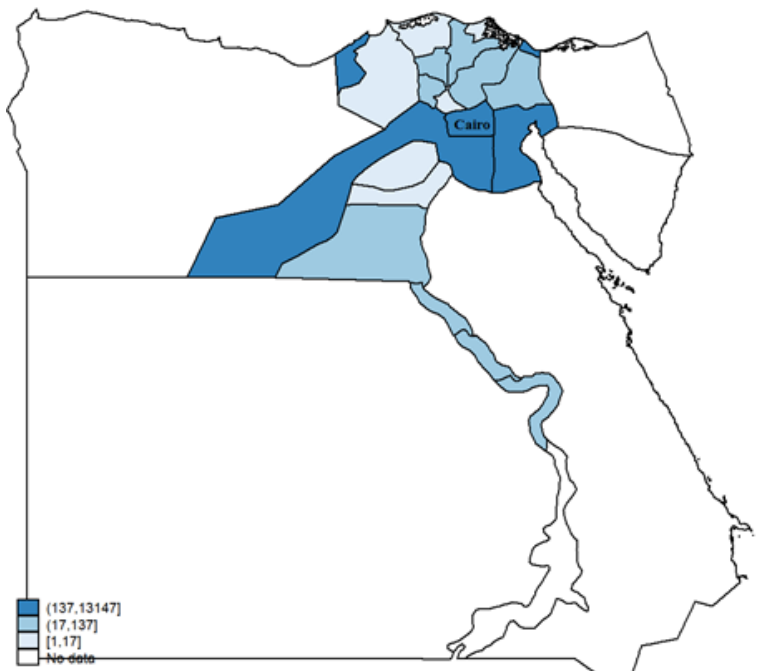

Notes: Data Source is the Statistical Database of the Egyptian Revolution.

Figure 4: Geographical Distribution of the Arrested from July 2013 to May 2014

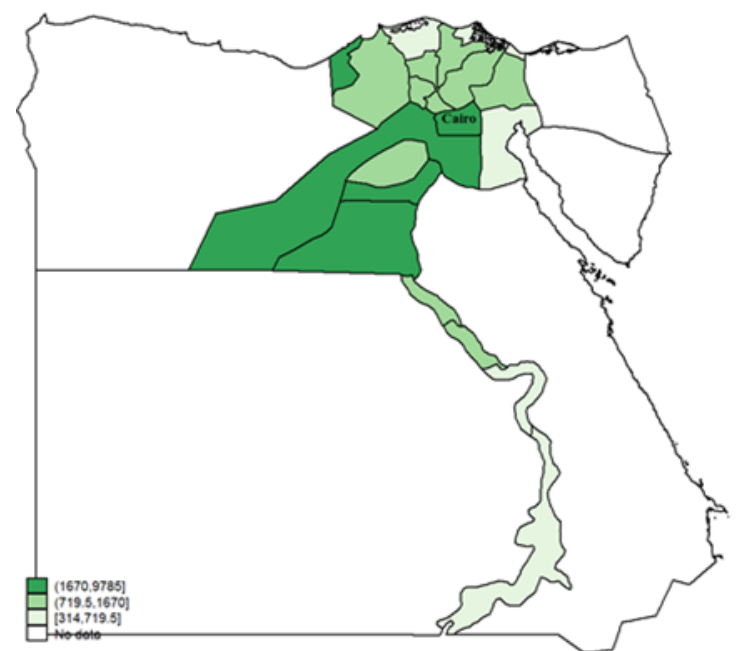

Notes: Data source is the Statistical Database of the Egyptian Revolution. 


\section{Figure 5: Participation in the Presidential Elections and Distance to the Capital Cairo}

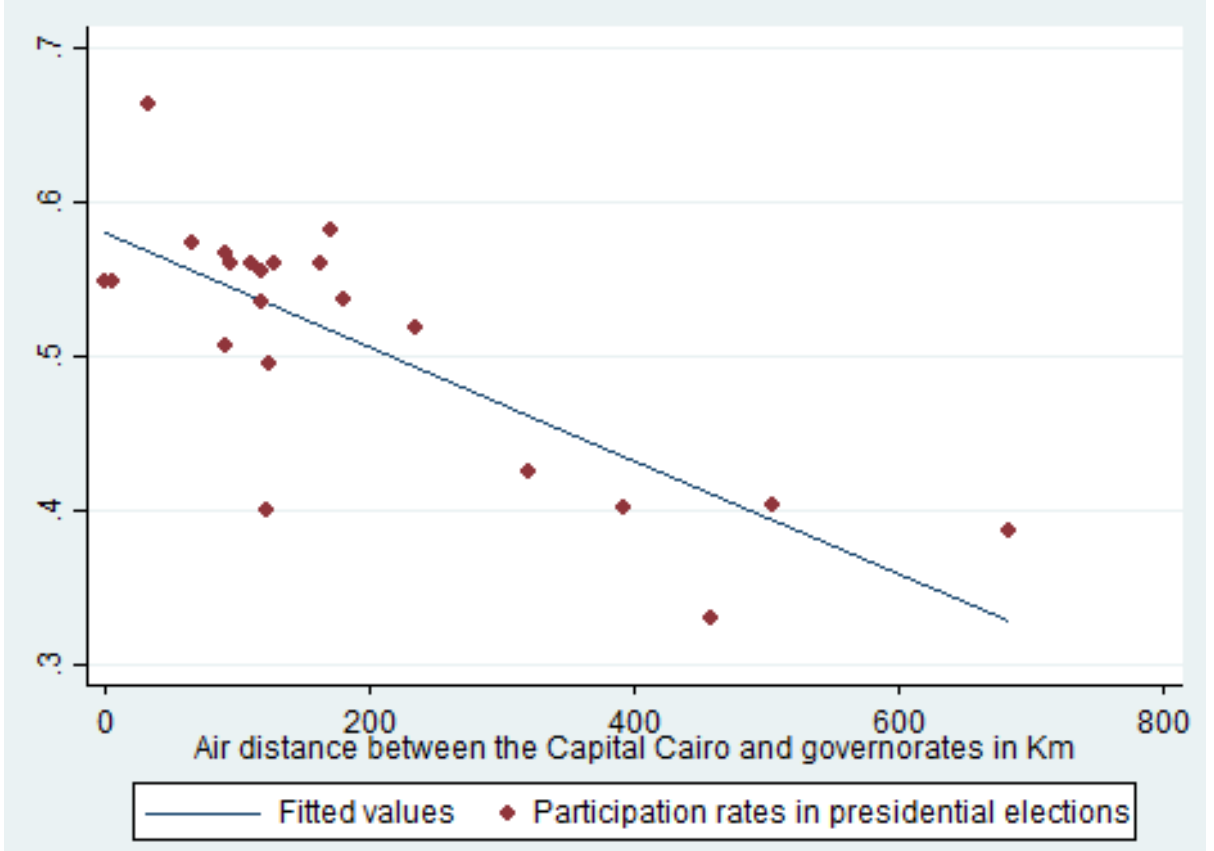

Notes. Data source is the official website of the Egyptian Presidential elections. On the vertical axis, we plot the participation rates in the second round of the Presidential elections between Mohamed Morsi and Ahmed Shafik, in June 2012. The participation rates are calculated as the ratio between the numbers of valid and invalid/spoilt votes with respect to the total number of enrolled voters by governorate. On the horizontal axis, we plot the air distance between the Capital Cairo and the Egyptian governorates in Km. The figure shows a scatter plot for the 22 Egyptian governorates in our dataset as well as a fitted line from regressing the participation rates in the Presidential elections of June 2012 on the distance to the Capital Cairo.

Figure 6: The Number of “Martyrs” Per Day, from January 2011 Till June 2012

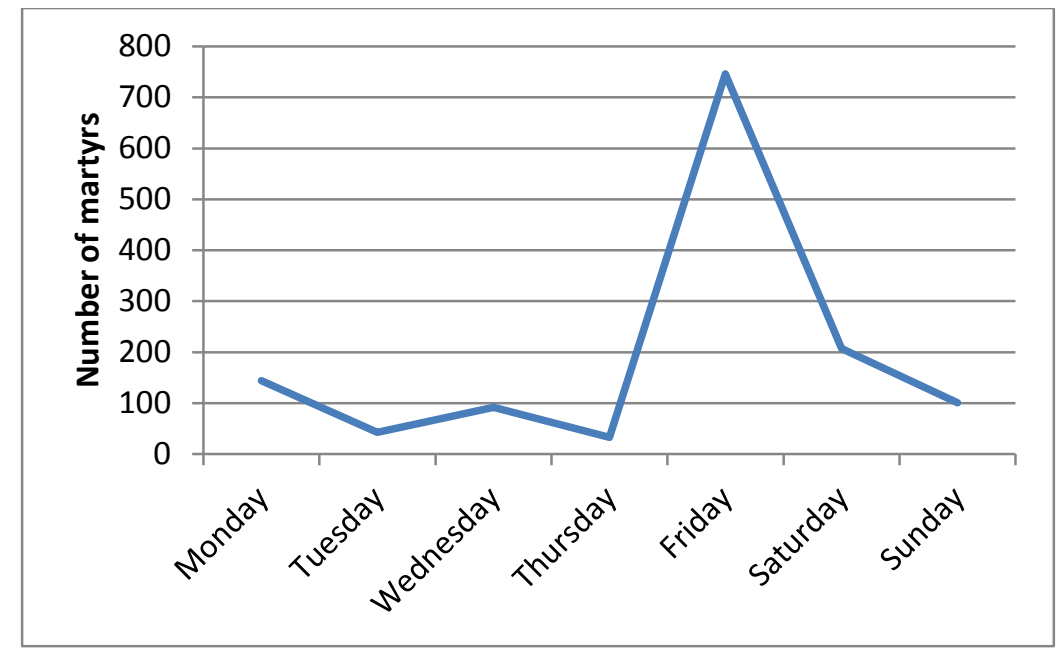

Notes: Data Source is the Statistical Database of the Egyptian Revolution. 
Table 1: Descriptive Statistics on Individuals' and Households' Characteristics

\begin{tabular}{|c|c|c|c|c|c|c|}
\hline \multirow{2}{*}{ Variables } & \multirow{2}{*}{ Observations } & \multicolumn{2}{|c|}{2006} & \multirow{2}{*}{ Observations } & \multicolumn{2}{|c|}{2012} \\
\hline & & Mean & St. Dev. & & Mean & St. Dev. \\
\hline \multicolumn{7}{|l|}{ Individual level controls } \\
\hline Ever-married & 14,035 & 0.705 & 0.456 & 14,035 & 0.810 & 0.392 \\
\hline No educational degree & 14,035 & 0.315 & 0.465 & 14,035 & 0.310 & 0.462 \\
\hline Primary/preparatory education & 14,035 & 0.193 & 0.394 & 14,035 & 0.150 & 0.357 \\
\hline Secondary education & 14,035 & 0.339 & 0.473 & 14,035 & 0.338 & 0.473 \\
\hline Above secondary education & 14,035 & 0.153 & 0.360 & 14,035 & 0.202 & 0.402 \\
\hline \multicolumn{7}{|l|}{ Household level characteristics } \\
\hline Rural & 5,499 & 0.479 & 0.500 & 6,850 & 0.496 & 0.500 \\
\hline Male headed & 5,499 & 0.869 & 0.338 & 6,850 & 0.879 & 0.327 \\
\hline Household size & 5,499 & 4.833 & 2.194 & 6,850 & 4.423 & 1.905 \\
\hline Number of adults $15-64$ years old & 5,499 & 2.916 & 1.435 & 6,850 & 2.491 & 1.391 \\
\hline Land ownership & 5,499 & 0.170 & 0.376 & 6,850 & 0.112 & 0.316 \\
\hline \multicolumn{7}{|l|}{ Household head characteristics } \\
\hline Single indicator & 5,499 & 0.017 & 0.129 & 6,850 & 0.007 & 0.084 \\
\hline No educational degree & 5,499 & 0.413 & 0.492 & 6,850 & 0.347 & 0.476 \\
\hline Primary/preparatory education & 5,499 & 0.161 & 0.367 & 6,850 & 0.169 & 0.375 \\
\hline Secondary education & 5,499 & 0.242 & 0.428 & 6,850 & 0.285 & 0.452 \\
\hline Above secondary education & 5,499 & 0.185 & 0.388 & 6,850 & 0.199 & 0.399 \\
\hline \multicolumn{7}{|c|}{ Measures of the intensity of the revolution } \\
\hline Number of martyrs & 22 & 0.627 & 1.199 & & & \\
\hline Number of injured & 21 & 7.946 & 28.540 & & & \\
\hline Number of arrested & 22 & 2.232 & 5.953 & & & \\
\hline \multicolumn{7}{|l|}{ Pre-revolution governorate controls } \\
\hline Share of public sector & 22 & 0.161 & 0.037 & & & \\
\hline Number of police stations & 22 & 0.061 & 0.045 & & & \\
\hline Mean youth education & 22 & 10.330 & 0.848 & & & \\
\hline Population density & 22 & 0.815 & 0.885 & & & \\
\hline Log of real GDP/capita & 22 & 8.669 & 0.111 & & & \\
\hline Fully urban governorate & 22 & 0.182 & 0.395 & & & \\
\hline
\end{tabular}

Notes. All reported descriptive statistics refer to sample individuals' and households' pre-revolution characteristics in 2006 as well in 2012. The number of households in 2006 and 2012 differs because of the presence of several split households in 2012. A split household is composed from a single or multiple individuals who left the original household either alone or with additional individuals who may have joined them later. Individual level controls include a dummy variable for ever-married status, four dummies for educational attainment: no education (either illiterate or literate without any diploma), primary and preparatory education, secondary education (either general or vocational) and above secondary education (either post-secondary institute or university education and above). Household level controls include a rural dummy, an indicator for male-headed households, household size, the number of adults aged 15 to 64 years old and a dummy variable for land ownership. Household head characteristics include: an indicator for the head of the household's marital status being single and four dummies for the head of the household's educational attainment. Governorate level controls are summarized by governorate. The number of "martyrs" represents the number of fatalities from the 25 $5^{\text {th }}$ of January 2011 to the end of June 2012, by governorate and is expressed in hundreds. The number of injured during the revolution is from the $11^{\text {th }}$ of February 2011 to the end of June 2012, by governorate and is expressed in hundreds. The number of arrested is reported from July 2012 to June 2013, by governorate, and is expressed in hundreds. Share of public sector represents the share of public sector employment by governorate in 2006. Police stations represent the number of police stations by governorate per 10,000 inhabitants. Mean youth education represents the average number of years of schooling for individuals aged 15-30, by governorate in 2006. Population density is equal to the total governorate population divided by the total land area in $\mathrm{km}^{2}$. This variable is expressed in thousands. The log of real governorate GDP per capita refers to the period 2005/2006. Fully urban governorate is a dummy variable equal to 1 for the following governorates: Cairo, Alexandria, Suez and Port Said. 
Table 2: Descriptive Statistics on Outcome Variables (Estimation Sample)

\begin{tabular}{|c|c|c|c|c|c|c|c|c|c|c|c|c|}
\hline \multirow[b]{2}{*}{ VARIABLES } & \multicolumn{4}{|c|}{ All sample } & \multicolumn{4}{|c|}{ Females } & \multicolumn{4}{|c|}{ Males } \\
\hline & $\begin{array}{c}\text { Initial } \\
\text { mean of } \\
\text { outcom } \\
\text { e }\end{array}$ & St. Dev. & $\begin{array}{c}\text { Mean of } \\
\text { change } \\
\text { in } \\
\text { outcome }\end{array}$ & St. Dev. & $\begin{array}{c}\text { Initial } \\
\text { mean of } \\
\text { outcome }\end{array}$ & St. Dev. & $\begin{array}{c}\text { Mean of } \\
\text { change } \\
\text { in } \\
\text { outcome }\end{array}$ & $\begin{array}{c}\text { St. } \\
\text { Dev. }\end{array}$ & $\begin{array}{c}\text { Initial } \\
\text { mean of } \\
\text { outcome }\end{array}$ & $\begin{array}{c}\text { St. } \\
\text { Dev. }\end{array}$ & $\begin{array}{c}\text { Mean of } \\
\text { change } \\
\text { in } \\
\text { outcome }\end{array}$ & St. Dev. \\
\hline Labor Force Participation & 0.574 & 0.494 & 0.05 & 0.461 & 0.293 & 0.455 & -0.003 & 0.499 & 0.811 & 0.392 & 0.095 & 0.422 \\
\hline Unemployment & 0.043 & 0.203 & 0.005 & 0.279 & 0.051 & 0.219 & 0.014 & 0.304 & 0.037 & 0.188 & -0.002 & 0.256 \\
\hline Employment & 0.531 & 0.499 & 0.045 & 0.448 & 0.243 & 0.429 & -0.017 & 0.432 & 0.774 & 0.418 & 0.097 & 0.456 \\
\hline Wage work & 0.343 & 0.475 & 0.074 & 0.453 & 0.131 & 0.337 & 0.024 & 0.278 & 0.521 & 0.500 & -0.021 & 0.453 \\
\hline Employer/Self-employed & 0.126 & 0.332 & -0.002 & 0.335 & 0.042 & 0.200 & -0.014 & 0.228 & 0.198 & 0.398 & 0.009 & 0.403 \\
\hline Unpaid family work & 0.158 & 0.364 & -0.064 & 0.375 & 0.273 & 0.445 & -0.105 & 0.474 & 0.06 & 0.238 & -0.03 & 0.261 \\
\hline Formal sector employment & 0.211 & 0.408 & 0.026 & 0.321 & 0.111 & 0.314 & 0.013 & 0.225 & 0.305 & 0.461 & 0.041 & 0.405 \\
\hline Informal sector employment & 0.274 & 0.446 & -0.007 & 0.405 & 0.107 & 0.310 & -0.058 & 0.309 & 0.432 & 0.495 & 0.052 & 0.487 \\
\hline Public sector employment & 0.174 & 0.379 & 0.014 & 0.289 & 0.108 & 0.311 & 0.012 & 0.218 & 0.229 & 0.420 & 0.016 & 0.338 \\
\hline Private sector employment & 0.356 & 0.479 & 0.03 & 0.445 & 0.134 & 0.341 & -0.031 & 0.385 & 0.544 & 0.498 & 0.082 & 0.485 \\
\hline Log of real hourly wage & 0.823 & 0.796 & 0.181 & 0.893 & 1.036 & 1.030 & 0.009 & 1.057 & 0.778 & 0.729 & 0.217 & 0.851 \\
\hline Log of real monthly wage & 3.899 & 2.974 & 1.114 & 2.329 & 3.187 & 3.025 & 0.342 & 1.157 & 4.088 & 2.932 & 1.250 & 2.454 \\
\hline Hours of work/week & 46.460 & 18.110 & -1.133 & 19.680 & 30.440 & 17.770 & 4.025 & 18.33 & 50.71 & 15.65 & -1.997 & 19.770 \\
\hline
\end{tabular}


Table 3: First Stage Regressions

\begin{tabular}{|c|c|c|c|c|}
\hline Variables & $\begin{array}{c}\text { (1) } \\
\text { Martyrs } \\
\end{array}$ & $\begin{array}{c}(2) \\
\text { Martyrs } \times \text { female } \\
\end{array}$ & $\begin{array}{c}(3) \\
\text { Martyrs } \\
\end{array}$ & $\begin{array}{c}(4) \\
\text { Martyrs } \times \text { female } \\
\end{array}$ \\
\hline Distance to the Capital & $\begin{array}{c}-0.527 * * * \\
{[0.071]}\end{array}$ & $\begin{array}{c}0.001 \\
{[0.002]}\end{array}$ & $\begin{array}{c}-0.268 * * * \\
{[0.026]}\end{array}$ & $\begin{array}{c}-0.000 \\
{[0.001]}\end{array}$ \\
\hline Distance to the Capital $\times$ female & $\begin{array}{l}-0.029 * \\
{[0.015]}\end{array}$ & $\begin{array}{c}-0.557 * * * \\
{[0.075]}\end{array}$ & $\begin{array}{c}-0.016^{* *} \\
{[0.007]}\end{array}$ & $\begin{array}{c}-0.285 * * * \\
{[0.027]}\end{array}$ \\
\hline Observations & 14,035 & 14,035 & 14,035 & 14,035 \\
\hline R-squared & 0.198 & 0.324 & 0.803 & 0.837 \\
\hline Individual Controls & YES & YES & YES & YES \\
\hline Household Controls & YES & YES & YES & YES \\
\hline Pre-revolution Governorate controls & & & YES & YES \\
\hline First stage F-statistic & 27.950 & 28.040 & 54.880 & 54.850 \\
\hline
\end{tabular}

Notes. Each cell represents a coefficient estimate using OLS estimation. The reported results correspond to the first stage regressions of the 2SLS estimation approach, where the distance to the capital Cairo (in hundreds of kilometers) and the distance to the capital Cairo (in hundreds of kilometers) interacted with a female dummy are used to instrument the number of "martyrs" by governorate and the interaction term between the number of "martyrs" by governorate and the female dummy. The number of "martyrs" represents the number of fatalities from the $25^{\text {th }}$ of January 2011 to the end of June 2012, by governorate and is expressed in hundreds. A female dummy is included which results from firstdifferencing our equation in level (from the interaction term between female and 2012 in Equation 1). Individual controls include the following variables in first-difference: a dummy variable for ever-married status, three dummies for educational attainment: primary and preparatory education, secondary education (either general or vocational) and above secondary education (either post-secondary institute or university education and above). The reference category is no educational degree (either illiterate or literate without any diploma). Household controls include the following variables in first difference: a rural dummy, an indicator for male headed household, household size, the number of adults aged 15 to 64 years old, a dummy variable for land ownership, an indicator for the head's marital status being single and three dummies for the head of the household's educational attainment. Pre-revolution governorate controls include the following variables as well as their interaction terms with a female dummy: the share of public sector employment by governorate in 2006, the number of police stations by governorate per 10,000 inhabitants, the average number of years of schooling for individuals aged 15-30 by governorate in 2006, the population density by governorate in 2006, the natural log of GDP per capita by governorate in 2005/2006 and a dummy variable for fully urban governorates (Cairo, Alexandria, Suez and Port Said). $* * * \mathrm{p}<0.01, * * \mathrm{p}<0.05, * \mathrm{p}<0.1$. Robust standard errors in brackets are clustered at the community level. The reported F-statistic corresponds to the first stage IV regression F-statistic. The Stock-Yogo weak identification test critical values for a single endogenous regressor are 16.38, 8.96, 6.66 and 5.53, at the $10 \%, 15 \%, 20 \%$ and $25 \%$ maximal IV size respectively. 
Table 4: Labor Force Participation, Unemployment and Employment

\begin{tabular}{|c|c|c|c|c|c|c|c|c|c|c|c|c|}
\hline & & & & & & & & & \multirow{2}{*}{\multicolumn{4}{|c|}{ Employment }} \\
\hline \multirow{3}{*}{ VARIABLES } & \multicolumn{4}{|c|}{ Labor Force Participation } & \multicolumn{4}{|c|}{ Unemployment } & & & & \\
\hline & (1) & (2) & (3) & (4) & (5) & (6) & (7) & (8) & (9) & (10) & (11) & (12) \\
\hline & OLS & IV & OLS & IV & OLS & IV & OLS & IV & OLS & IV & OLS & IV \\
\hline \multirow[t]{2}{*}{ Martyrs $\times$ female } & $0.019 * * *$ & $0.097 * * *$ & 0.005 & $0.138 * * *$ & 0.001 & $0.018^{* * *}$ & 0.009 & $0.053 * * *$ & $0.018 * * *$ & $0.079 * * *$ & -0.004 & $0.085 * *$ \\
\hline & [0.005] & {$[0.021]$} & {$[0.010]$} & {$[0.036]$} & {$[0.004]$} & {$[0.006]$} & {$[0.007]$} & {$[0.016]$} & {$[0.005]$} & {$[0.020]$} & {$[0.009]$} & {$[0.035]$} \\
\hline \multirow[t]{2}{*}{ Martyrs } & $-0.010 * * *$ & $-0.017 * * *$ & -0.000 & $-0.028 * *$ & -0.003 & -0.004 & -0.006 & -0.013 & $-0.008^{*}$ & -0.012 & 0.006 & -0.015 \\
\hline & [0.002] & {$[0.006]$} & {$[0.005]$} & {$[0.014]$} & {$[0.003]$} & {$[0.004]$} & {$[0.005]$} & {$[0.011]$} & {$[0.004]$} & {$[0.007]$} & {$[0.006]$} & {$[0.018]$} \\
\hline Observations & 14,035 & 14,035 & 14,035 & 14,035 & 14,035 & 14,035 & 14,035 & 14,035 & 14,035 & 14,035 & 14,035 & 14,035 \\
\hline R-squared & 0.131 & 0.095 & 0.142 & 0.123 & 0.043 & 0.038 & 0.045 & 0.039 & 0.087 & 0.063 & 0.097 & 0.088 \\
\hline Individual Controls & YES & YES & YES & YES & YES & YES & YES & YES & YES & YES & YES & YES \\
\hline Household Controls & YES & YES & YES & YES & YES & YES & YES & YES & YES & YES & YES & YES \\
\hline Pre-revolution governorate controls & & & YES & YES & & & YES & YES & & & YES & YES \\
\hline $\mathrm{H}_{0}: \alpha_{1}+\alpha_{2}=0$ (P-value) & 0.055 & 0.000 & 0.599 & 0.001 & 0.397 & 0.010 & 0.608 & 0.003 & 0.003 & 0.000 & 0.787 & 0.018 \\
\hline Kleibergen-Paap rk Wald F statistic & & 20.936 & & 39.467 & & 20.936 & & 39.467 & & 20.936 & & 39.467 \\
\hline
\end{tabular}
number of “martyrs" by governorate and the interaction term between the number of "martyrs" by governorate and the female dummy. The number of "martyrs" represents the number of fatalities from the $25^{\text {th }}$ of January 2011 to the end of June 2012, by governorate and is expressed in hundreds. A female dummy is included which results from first-differencing our equation in level (from the interaction term between female and 2012 in Equation 1). The dependent variable and all control variables are first-differenced. Labor force participation, unemployment and employment are defined according to the current work status. The reference period for the labor market information is 3 months. The labor force includes all those who are engaged in economic activity for purposes of market exchange and excludes subsistence workers, following the market definition of economic activity (see ILO, 1982).Individual controls include the following variables in first-difference: a dummy variable for ever-married status, three dummies for educational attainment: primary and preparatory education, secondary education (either general or vocational) and above secondary education (either post-secondary institute or university education and above). The reference category is no educational degree (either illiterate or literate without any diploma). Household controls include the following variables in first difference: a rural dummy, an indicator for male headed household, household size, the number of adults aged 15 to 64 years old, a dummy variable for land ownership, an indicator for the head's marital status being single and three dummies for the head of the household's educational attainment. Pre-revolution governorate controls include the following variables as well as their interaction terms with a female dummy: the share of public sector employment by governorate in 2006, the number of police stations by governorate per 10,000 inhabitants, the average number of years of schooling for individuals aged 15-30 by governorate in 2006, the population density by governorate in 2006, the natural log of GDP per capita by governorate in 2005/2006 and a dummy variable for fully urban governorates (Cairo, Alexandria, Suez and Port Said) *** $\mathrm{p}<0.01, * * \mathrm{p}<0.05$ * $\mathrm{p}<0.1$. Robust standard errors in brackets are clustered at the community level. The reported Kleibergen-Paap rk Wald F-statistic corresponds to the first stage IV regression F-statistic. The Stock-Yogo weak identification test critical values are 7.03, 4.58, 3.95 and 3.63, at the 10\%, 15\%, 20\% and 25\% maximal IV size respectively. The table also reports the p-value of a test with null hypothesis $\alpha_{1}+\alpha_{2}=0$ to check whether the protests significantly affect women's outcomes of interest. 
Table 5: Public and Private Sector Employment

\begin{tabular}{|c|c|c|c|c|c|c|c|c|}
\hline \multirow[b]{3}{*}{ VARIABLES } & \multicolumn{4}{|c|}{ Private sector employment } & \multicolumn{4}{|c|}{ Public sector employment } \\
\hline & (1) & (2) & (3) & (4) & (5) & (6) & (7) & (8) \\
\hline & OLS & IV & OLS & IV & OLS & IV & OLS & IV \\
\hline \multirow[t]{2}{*}{ Martyrs $\times$ female } & $0.015^{* *}$ & $0.066^{* * *}$ & -0.012 & $0.059 *$ & 0.003 & $0.014^{* *}$ & 0.007 & $0.027^{*}$ \\
\hline & {$[0.006]$} & {$[0.020]$} & [0.010] & [0.034] & [0.003] & {$[0.006]$} & {$[0.006]$} & {$[0.016]$} \\
\hline \multirow[t]{2}{*}{ Martyrs } & -0.003 & 0.003 & $0.014^{*}$ & 0.014 & -0.004 & $-0.015 * * *$ & -0.007 & $-0.026 *$ \\
\hline & {$[0.005]$} & [0.008] & [0.008] & [0.018] & [0.003] & [0.005] & {$[0.005]$} & {$[0.014]$} \\
\hline Observations & 13,919 & 13,919 & 13,919 & 13,919 & 13,919 & 13,919 & 13,919 & 13,919 \\
\hline R-squared & 0.048 & 0.023 & 0.060 & 0.051 & 0.029 & 0.027 & 0.031 & 0.029 \\
\hline Individual Controls & YES & YES & YES & YES & YES & YES & YES & YES \\
\hline Household Controls & YES & YES & YES & YES & YES & YES & YES & YES \\
\hline Pre-revolution governorate controls & & & YES & YES & & & YES & YES \\
\hline $\mathrm{H}_{0}: \alpha_{1}+\alpha_{2}=0$ (P-value) & 0.002 & 0.000 & 0.772 & 0.014 & 0.597 & 0.738 & 0.893 & 0.900 \\
\hline Kleibergen-Paap rk Wald F statistic & & 20.883 & & 39.500 & & 20.883 & & 39.500 \\
\hline
\end{tabular}

Notes. Each cell represents a coefficient estimate using OLS or IV regressions, where the distance to the capital Cairo and the distance to the capital Cairo interacted with a female dummy are used to instrument the number of "martyrs" by governorate and the interaction term between the number of "martyrs" by governorate and the female dummy. The number of "martyrs" represents the number of fatalities from the $25^{\text {th }}$ of January 2011 to the end of June 2012, by governorate and is expressed in hundreds. A female dummy is included which results from first-differencing our equation in level (from the interaction term between female and 2012 in Equation 1). The dependent variable and all control variables are first-differenced. Private and public sector employment are defined according to the economic sector of primary job, reference period 1 week. Individual controls include the following variables in first-difference: a dummy variable for ever-married status, three dummies for educational attainment: primary and preparatory education, secondary education (either general or vocational) and above secondary education (either post-secondary institute or university education and above). The reference category is no educational degree (either illiterate or literate without any diploma). Household controls include the following variables in first difference: a rural dummy, an indicator for male headed household, household size, the number of adults aged 15 to 64 years old, a dummy variable for land ownership, an indicator for the head's marital status being single and three dummies for the head of the household's educational attainment. Pre-revolution governorate controls include the following variables as well as their interaction terms with a female dummy: the share of public sector employment by governorate in 2006, the number of police stations by governorate per 10,000 inhabitants, the average number of years of schooling for individuals aged 15-30 by governorate in 2006, the population density by governorate in 2006, the natural log of GDP per capita by governorate in 2005/2006 and a dummy variable for fully urban governorates for individuals aged $15-30$ by governorate in 2006, the population density by governorate in 2006, the natural log of GDP per capita by governorate in $2005 / 2006$ and a dummy variable for fully urban governorates
(Cairo, Alexandria, Suez and Port Said).*** $<<0.01, * * p<0.05, * p<0.1$. Robust standard errors in brackets are clustered at the community level. The reported Kleibergen-Paap rk Wald F-statistic corresponds to the first (Cairo, Alexandria, Suez and Port Said). $* * * \mathrm{p}<0.01, * * \mathrm{p}<0.05, * \mathrm{p}<0.1$. Robust standard errors in brackets are clustered at the community level. The reported Kleibergen-Paap rk Wald F-statistic corresponds to the first test with null hypothesis $\alpha_{1}+\alpha_{2}=0$ to check whether the protests significantly affect women's outcomes of interest. 
Table 6: Differential gender effects of the protests on Monthly, Hourly wages and Hours worked per week

\begin{tabular}{|c|c|c|c|c|c|c|}
\hline & \multicolumn{2}{|c|}{ Log of Monthly wage } & \multicolumn{2}{|c|}{ Log of hourly wage } & \multicolumn{2}{|c|}{ Hours worked/week } \\
\hline & (1) & (2) & (3) & (4) & (5) & (6) \\
\hline VARIABLES & OLS & IV & OLS & IV & OLS & IV \\
\hline \multirow[t]{2}{*}{ Martyrs $\times$ female } & $-0.061 *$ & 0.156 & -0.000 & 0.090 & -0.086 & $3.669^{* *}$ \\
\hline & {$[0.036]$} & [0.099] & [0.040] & {$[0.108]$} & {$[0.740]$} & [1.604] \\
\hline \multirow[t]{2}{*}{ Martyrs } & 0.008 & -0.106 & -0.000 & -0.105 & $-0.818^{* *}$ & $-3.668 * * *$ \\
\hline & {$[0.022]$} & {$[0.070]$} & [0.021] & {$[0.066]$} & [0.409] & [1.203] \\
\hline Observations & 3,738 & 3,738 & 3,738 & 3,738 & 3,738 & 3,738 \\
\hline R-squared & 0.024 & 0.010 & 0.039 & 0.030 & 0.025 & 0.007 \\
\hline Individual Controls & YES & YES & YES & YES & YES & YES \\
\hline Household Controls & YES & YES & YES & YES & YES & YES \\
\hline Pre-revolution governorate controls & YES & YES & YES & YES & YES & YES \\
\hline $\mathrm{H} 0: \alpha_{1}+\alpha_{2}=0$ (P-value) & 0.079 & 0.528 & 0.995 & 0.866 & 0.160 & 0.999 \\
\hline Kleibergen-Paap rk Wald F statistic & & 32.588 & & 32.588 & & 32.588 \\
\hline
\end{tabular}

Notes. Each cell represents a coefficient estimate using OLS or IV regressions, where the distance to the capital Cairo and the distance to the capital Cairo interacted with a female dummy are used to instrument the number of "martyrs" by governorate and the interaction term between the number of "martyrs" by governorate and the female dummy. The number of "martyrs" represents the number of fatalities from the 25th of January 2011 to the end of June 2012, by governorate and is expressed in hundreds. A female dummy is included which results from first-differencing our equation in level (from the interaction term between female and 2012 in Equation 1). The dependent variable and all control variables are first-differenced. Monthly and hourly wages are calculated in constant 2006 Egyptian Pounds and refer to the monthly/hourly wage in primary job, conditional on being employed, in log specification. The hours of work refer to the current number of work hours per week, excluding subsistence work (market definition of economic activity) and conditional on being employed. Individual controls include the following variables in first-difference: a dummy variable for ever-married status, three dummies for educational attainment: primary and preparatory education, secondary education (either general or vocational) and above secondary education (either post-secondary institute or university education and above). The reference category is no educational degree (either illiterate or literate without any diploma). Household controls include the following variables in first difference: a rural dummy, an indicator for male headed household, household size, the number of adults aged 15 to 64 years old, a dummy variable for land ownership, an indicator for the head's marital status being single and three dummies for the head of the household's educational attainment. The reference category is the non-working category. Pre-revolution governorate controls include the following variables as well as their interaction terms with a female dummy: the share of public sector employment by governorate in 2006, the number of police stations by governorate per 10,000 inhabitants, the average number of years of schooling for individuals aged 15-30 by governorate in 2006, the population density by governorate in 2006, the natural log of GDP per capita by governorate in 2005/2006 and a dummy variable for fully urban governorates (Cairo, Alexandria, Suez and Port Said). *** $p<0.01$, ** $p<0.05$, * $p<0.1$. Robust standard errors in brackets are clustered at the community level. The reported Kleibergen-Paap rk Wald F-statistic corresponds to the first stage IV regression F-statistic. The Stock-Yogo weak identification test critical values are 7.03, 4.58, 3.95 and 3.63, at the 10\%, 15\%, 20\% and $25 \%$ maximal IV size respectively. The table also reports the p-value of a test with null hypothesis $\alpha_{1}+\alpha_{2}=0$ to check whether the protests significantly affect women's outcomes of interest. 
Table 7: Variance of Monthly Wage

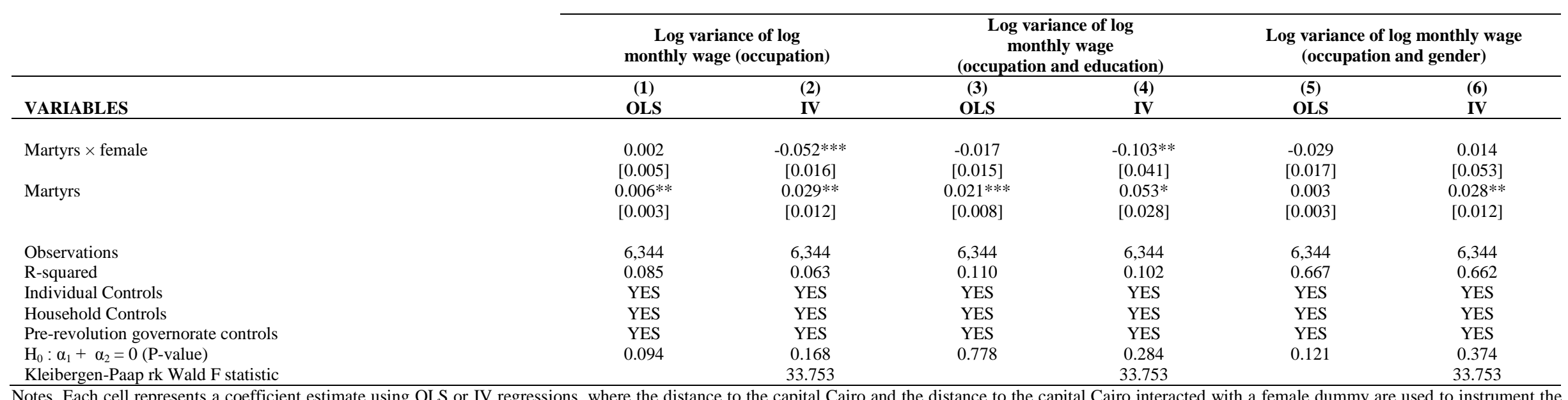

Notes. Each cell represents a coefficient estimate using OLS or IV regressions, where the distance to the capital Cairo and the distance to the capital Cairo interacted with a female dummy are used to instrument the number of "martyrs" by governorate and the interaction term between the number of "martyrs" by governorate and the female dummy. The number of "martyrs" represents the number of fatalities from the 25th of January 2011 to the end of June 2012, by governorate and is expressed in hundreds. A female dummy is included which results from first-differencing our equation in level (from the interaction term between female and 2012 in Equation 1). The dependent variable and all control variables are first-differenced. We use a conventional risk measure: the logarithm of the variance of the logarithm of wage. The monthly wage is expressed in constant 2006 Egyptian Pounds and refers to the monthly wage in primary job. We construct this measure by occupation using 4 occupational groups, by occupation and education using 4 occupational groups and 4 educational levels, and by occupation and gender, using the same occupational groups. The occupational groups are defined according to the ISCO-88 occupation classification: low-skilled blue collar, high-skilled blue collar, lowskilled white collar and high-skilled white collar. The educational levels are the following: no education, primary/preparatory education, secondary education and above secondary education. Individual controls include the following variables in first-difference: a dummy variable for ever-married status, three dummies for educational attainment: primary and preparatory education, secondary education (either general or vocational) and above secondary education (either post-secondary institute or university education and above). The reference category is no educational degree (either illiterate or literate without any diploma). Household controls include the following variables in first difference• a rural dummy, an indicator for male headed household, household size, the number of adults aged 15 to 64 years old, a dummy variable for land ownership, an indicator for the head's maital stas being single and thro dummies for the head of the huts fem so by gover (Cairo, Alexandia, Suez and Port Said). The Stock-Yogo weak identification test critical values are 7.03, 4.58, 3.95 and 3.63, at the $10 \%, 15 \%, 20 \%$ and $25 \%$ maximal IV size respectively. The table also reports the p-value of a test with null hypothesis $\alpha_{1}+\alpha_{2}=0$ to check whether the protests significantly affect women's outcomes of interest. 
Table 8: Other Potential Mechanisms

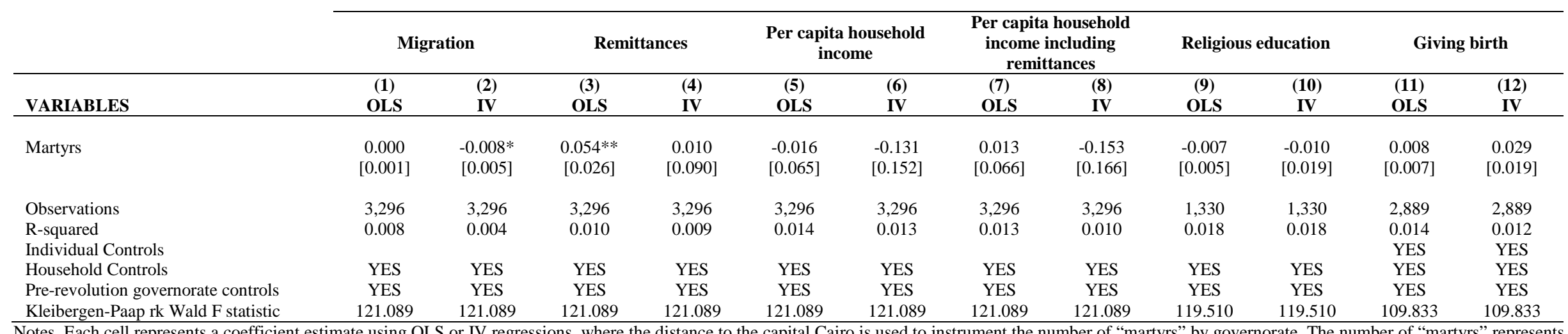

Notes. Each cell represents a coefficient estimate using OLS or IV regressions, where the distance to the capital Cairo is used to instrument the number of "martyrs" by governorate. The number of "martyrs" represents

the number of fatalities from the 25th of January 2011 to the end of June 2012, by governorate and is expressed in hundreds. The dependent variable and all control variables are first-differenced. The dependent variable in column (1) and (2) corresponds to migration at the household level. It is equal to 1 if households report having a household member living or working abroad. The dependent variable in column (3) and (4) corresponds to the log of the total value of remittances received by households in cash and/or in kind from all listed migrants, during the last 12 months preceding the survey. The dependent variable in column (5) and (6) corresponds to the log of per capita household income. The dependent variable in column (7) and (8) corresponds to the log of per capita household income including remittances. Remittances, per capita household income and per capita household income including remittances are expressed in Egyptian Pounds (EGP), in constant terms (2006 EGP). The dependent variable in column (9) and (10) corresponds to religious education (Azhari education). It is equal to the number of individuals studying at religious schools (Azhari) at the time of the survey over the total number of individuals currently studying at the household level. This ratio is calculated on a subsample of individuals who are currently studying at the time of the surveys in 2006 and 2012. The dependent variable in columns (11) and (12) corresponds to the first difference between the probability of giving birth after the revolution between the 25th of October 2011 (9 months after the 25th of January 2011 revolution) and the day of visit for the survey interview, and the probability of giving birth for the same time interval prior to the 2006 round, only focusing on married females aged 18 to 49 years old. Individual controls in columns (11) and (12) include the following variables in first-difference: three dummies for educational attainment: primary and preparatory education, secondary education (either general or vocational) and above secondary education (either post-secondary institute or university education and above). The reference category is no educational degree (either illiterate or literate without any diploma). Household controls include the following variables in first difference: a rural dummy, an indicator for male headed household, household size, the number of adults aged 15 to 64 years old, a dummy variable for land ownership, an indicator for the head's marital status being single and three dummies for the head of the household's educational attainment. Prerevolution govich of yes of (in fully corresponds to the first stage IV regression F-statistic. The Stock-Yogo weak identification test critical values are 16.38, 8.96, 6.66 and 5.53, at the 10\%, 15\%, 20\% and 25\% maximal IV size respectively. 
Table 9: The Number of "Martyrs” Per Day

\begin{tabular}{lcc}
\hline Day & Number of martyrs & Percentage of martyrs \\
\hline Monday & 144 & 0.105 \\
Tuesday & 43 & 0.031 \\
Wednesday & 92 & 0.067 \\
Thursday & 33 & 0.024 \\
Friday & 746 & 0.546 \\
Saturday & 207 & 0.152 \\
Sunday & 101 & 0.074 \\
Total & 1366 & 1.000 \\
\hline Notes. Data source is the Statistical Database of the Egyptian Revolution. & The number of "martyrs” per day is from January 2011 till June \\
2012. & &
\end{tabular}


Table 10: Robustness Checks Using Other Measures of the Revolution

\begin{tabular}{|c|c|c|c|c|c|c|}
\hline \multicolumn{7}{|c|}{ Panel A: Using the number of injured by governorate } \\
\hline & \multicolumn{2}{|c|}{ Labor Force Participation } & \multicolumn{2}{|c|}{ Unemployment } & \multicolumn{2}{|c|}{ Employment } \\
\hline & (1) & (2) & (3) & (4) & (5) & (6) \\
\hline VARIABLES & OLS & IV & OLS & IV & OLS & IV \\
\hline \multirow[t]{2}{*}{ Injured $\times$ female } & 0.000 & $0.009 * * *$ & 0.000 & $0.003^{* * *}$ & -0.000 & $0.006 * * *$ \\
\hline & {$[0.000]$} & {$[0.003]$} & {$[0.000]$} & {$[0.001]$} & {$[0.000]$} & {$[0.002]$} \\
\hline \multirow[t]{2}{*}{ Injured } & -0.000 & -0.001 & -0.000 & -0.001 & 0.000 & -0.001 \\
\hline & {$[0.000]$} & [0.001] & {$[0.000]$} & {$[0.001]$} & [0.000] & {$[0.001]$} \\
\hline Observations & 13,444 & 13,444 & 13,444 & 13,444 & 13,444 & 13,444 \\
\hline R-squared & 0.141 & 0.068 & 0.045 & 0.028 & 0.097 & 0.057 \\
\hline Individual Controls & YES & YES & YES & YES & YES & YES \\
\hline Household Controls & YES & YES & YES & YES & YES & YES \\
\hline \multicolumn{7}{|l|}{ Pre-revolution Governorate } \\
\hline Controls & YES & YES & YES & YES & YES & YES \\
\hline $\mathrm{H}_{0}: \alpha_{1}+\alpha_{2}=0$ (P-value) & 0.944 & 0.000 & 0.825 & 0.003 & 0.928 & 0.006 \\
\hline Kleibergen-Paap rk Wald F statistic & & 10.912 & & 10.912 & & 10.912 \\
\hline \multicolumn{7}{|c|}{ Panel B: Using the number of arrested by governorate } \\
\hline & \multicolumn{2}{|c|}{ Labor Force Participation } & \multicolumn{2}{|c|}{ Unemployment } & \multicolumn{2}{|c|}{ Employment } \\
\hline & (1) & (2) & (3) & (4) & (5) & (6) \\
\hline VARIABLES & OLS & IV & OLS & IV & OLS & IV \\
\hline \multirow[t]{2}{*}{ Arrested $\times$ female } & -0.001 & $0.050 * * *$ & 0.002 & $0.019 * * *$ & $-0.003 *$ & $0.031 *$ \\
\hline & [0.002] & [0.019] & [0.001] & [0.007] & [0.002] & {$[0.016]$} \\
\hline \multirow[t]{2}{*}{ Arrested } & 0.000 & $-0.011^{*}$ & -0.001 & -0.005 & 0.001 & -0.006 \\
\hline & {$[0.001]$} & {$[0.006]$} & {$[0.001]$} & {$[0.004]$} & {$[0.001]$} & {$[0.007]$} \\
\hline Observations & 14,035 & 14,035 & 14,035 & 14,035 & 14,035 & 14,035 \\
\hline R-squared & 0.142 & 0.065 & 0.045 & 0.020 & 0.097 & 0.062 \\
\hline Individual Controls & YES & YES & YES & YES & YES & YES \\
\hline Household Controls & YES & YES & YES & YES & YES & YES \\
\hline \multicolumn{7}{|l|}{ Pre-revolution Governorate } \\
\hline Controls & YES & YES & YES & YES & YES & YES \\
\hline $\mathrm{H}_{0}: \alpha_{1}+\alpha_{2}=0$ (P-value) & 0.667 & 0.012 & 0.522 & 0.009 & 0.296 & 0.057 \\
\hline Kleibergen-Paap rk Wald F statistic & & 5.838 & & 5.838 & & 5.838 \\
\hline
\end{tabular}

Notes. Each cell represents a coefficient estimate using OLS or IV regressions, where the distance to the capital Cairo and the distance to the capital Cairo interacted with a female dummy are used to instrument the number of injured/arrested by governorate and the interaction term between the number of injured/arrested by governorate and the female dummy. The number of injured is expressed in hundreds and is equal to the number of injured by governorate from the $11^{\text {th }}$ of February 2011 to the end of June 2012. The number of arrested is expressed in hundreds and is equal to the number of arrested by governorate from July 2012 to June 2013. A female dummy is included which results from first-differencing our equation in level (from the interaction term between female and 2012 in Equation 1). The dependent variable and all control variables are first-differenced. Labor force participation, unemployment and employment are defined according to the current work status. The reference period for the labor market information is 3 months. The labor force includes all those who are engaged in economic activity for purposes of market exchange and excludes subsistence workers, following the market definition of economic activity (see ILO, 1982).Individual controls include the following variables in first-difference: a dummy variable for ever-married status, three dummies for educational attainment: primary and preparatory education, secondary education (either general or vocational) and above secondary education (either post-secondary institute or university education and above). The reference category is no educational degree (either illiterate or literate without any diploma). Household controls include the following variables in first difference: a rural dummy, an indicator for male headed household, household size, the number of adults aged 15 to 64 years old, a dummy variable for land ownership, an indicator for the head's marital status being single and three dummies for the head of the household's educational attainment. Pre-revolution governorate controls include the following variables as well as their interaction terms with a female dummy: the share of public sector employment by governorate in 2006, the number of police stations by governorate per 10,000 inhabitants, the average number of years of schooling for individuals aged $15-30$ by governorate in 2006, the population density by governorate in 2006, the natural log of GDP per capita by governorate in 2005/2006 and a dummy variable for fully urban governorates (Cairo, Alexandria, Suez and Port Said). ${ }^{* * *} \mathrm{p}<0.01,{ }^{* *} \mathrm{p}<0.05,{ }^{*} \mathrm{p}<0.1$. Robust standard errors in brackets are clustered at the community level. The reported Kleibergen-Paap rk Wald F-statistic corresponds to the first stage IV regression F-statistic. The Stock-Yogo weak identification test critical values are 7.03, 4.58, 3.95 and 3.63, at the 10\%, 15\%, 20\% and 25\% maximal IV size respectively. The table also reports the p-value of a test with null hypothesis $\alpha_{1}+\alpha_{2}=0$ to check whether the protests significantly affect women's outcomes of interest. 
Table 11: Other Robustness Checks

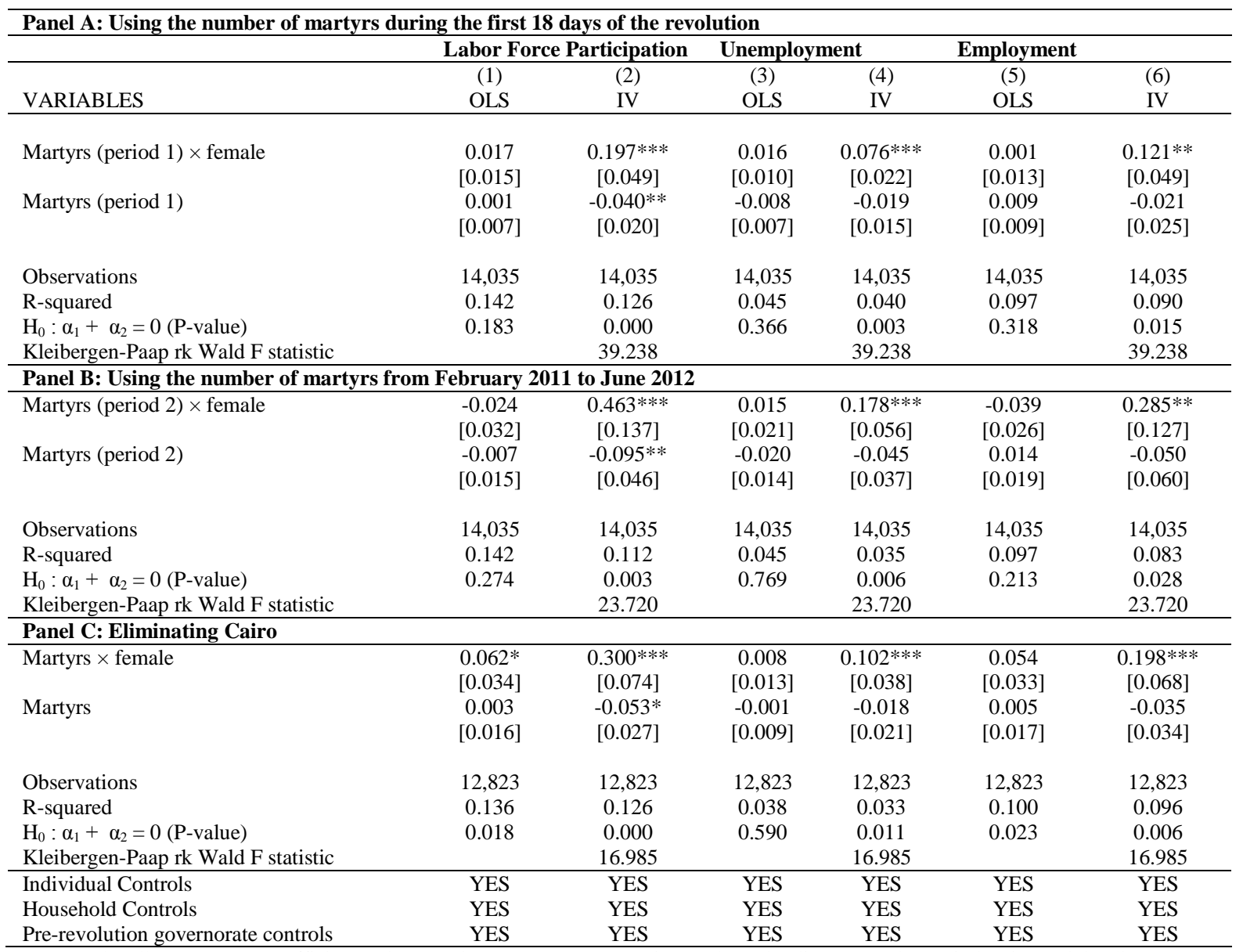

Notes. Each cell represents a coefficient estimate using OLS or IV regressions, where the distance to the capital Cairo and the distance to the capital Cairo interacted with a female dummy are used to instrument the number of "martyrs" by governorate and the interaction term between the number of "martyrs" by governorate and the female dummy. In Panel A, we use the number of "martyrs" by governorate during the first 18 days of the revolution, from $25^{\text {th }}$ of January to the $11^{\text {th }}$ of February 2011, expressed in hundreds. In Panel B, we use the number of "martyrs" by governorate, from the $12^{\text {th }}$ of February 2011 to the end of June 2012, expressed in hundreds. In Panel C, we eliminate the Capital Cairo and use the standard definition of "martyrs", fatalities from the $25^{\text {th }}$ of January 2011 till the end of June 2012. A female dummy is included which results from first-differencing our equation in level (from the interaction term between female and 2012 in Equation 1). The dependent variable and all control variables are first-differenced. Labor force participation, unemployment and employment are defined according to the current work status. The reference period for the labor market information is 3 months. The labor force includes all those who are engaged in economic activity for purposes of market exchange and excludes subsistence workers, following the market definition of economic activity (see ILO, 1982). Individual controls include the following variables in first-difference: a dummy variable for ever-married status, three dummies for educational attainment: primary and preparatory education, secondary education (either general or vocational) and above secondary education (either post-secondary institute or university education and above). The reference category is no educational degree (either illiterate or literate without any diploma). Household controls include the following variables in first difference: a rural dummy, an indicator for male headed household, household size, the number of adults aged 15 to 64 years old, a dummy variable for land ownership, an indicator for the head's marital status being single and three dummies for the head of the household's educational attainment. Pre-revolution governorate controls include the following variables as well as their interaction terms with a female dummy: the share of public sector employment by governorate in 2006, the number of police stations by governorate per 10,000 inhabitants, the average number of years of schooling for individuals aged 15-30 by governorate in 2006, the population density by governorate in 2006, the natural log of GDP per capita by governorate in 2005/2006 and a dummy variable for fully urban governorates (Cairo, Alexandria, Suez and Port Said). *** p<0.01, ** $\mathrm{p}<0.05, * \mathrm{p}<0.1$. Robust standard errors in brackets are clustered at the community level. The reported Kleibergen-Paap rk Wald F-statistic corresponds to the first stage IV regression F-statistic. The Stock-Yogo weak identification test critical values are 7.03, 4.58, 3.95 and 3.63, at the $10 \%, 15 \%, 20 \%$ and $25 \%$ maximal IV size respectively. The table also reports the p-value of a test with null hypothesis $\alpha_{1}+\alpha_{2}=0$ to check whether the protests significantly affect women's outcomes of interest. 
Table 12: Placebo Regressions: The Impact of The 2011 Revolution on Individuals' Labor Market Outcomes in 1998-2006 Panel A: IV Estimates

\begin{tabular}{|c|c|c|c|c|c|c|c|c|c|c|c|c|c|}
\hline & $\begin{array}{l}\text { Labor Force } \\
\text { Particip. }\end{array}$ & $\begin{array}{c}\text { Unemploy } \\
\text { ment }\end{array}$ & $\begin{array}{l}\text { Employ } \\
\text { ment }\end{array}$ & $\begin{array}{l}\text { Wage } \\
\text { work }\end{array}$ & $\begin{array}{l}\text { Employer/ } \\
\text { Self } \\
\text { employed }\end{array}$ & $\begin{array}{c}\text { Unpaid } \\
\text { family } \\
\text { work }\end{array}$ & $\begin{array}{c}\text { Formal } \\
\text { sector emp. }\end{array}$ & $\begin{array}{c}\text { Informal } \\
\text { sector } \\
\text { emp. }\end{array}$ & $\begin{array}{l}\text { Public } \\
\text { sector } \\
\text { emp. }\end{array}$ & $\begin{array}{l}\text { Private } \\
\text { sector } \\
\text { emp. }\end{array}$ & $\begin{array}{c}\text { Log of } \\
\text { monthly } \\
\text { wage }\end{array}$ & $\begin{array}{c}\text { Log of } \\
\text { hourly } \\
\text { wage }\end{array}$ & $\begin{array}{c}\text { Hours } \\
\text { worked/ } \\
\text { week }\end{array}$ \\
\hline & (1) & (2) & (3) & (4) & (5) & (6) & (7) & (8) & (9) & $(10)$ & (11) & (12) & (13) \\
\hline VARIABLES & IV & IV & IV & IV & IV & IV & IV & IV & IV & IV & IV & IV & IV \\
\hline Martyrs $\times$ female & -0.034 & -0.052 & 0.018 & -0.054 & 0.033 & 0.127 & -0.008 & -0.053 & 0.016 & 0.010 & -0.178 & -0.126 & -2.334 \\
\hline Martyrs & $\begin{array}{l}{[0.089]} \\
0.040^{*} \\
{[0.023]}\end{array}$ & $\begin{array}{c}{[0.033]} \\
0.024 \\
{[0.015]}\end{array}$ & $\begin{array}{c}{[0.104]} \\
0.016 \\
{[0.017]}\end{array}$ & $\begin{array}{l}{[0.034]} \\
0.053^{*} \\
{[0.029]}\end{array}$ & $\begin{array}{l}{[0.035]} \\
-0.020 \\
{[0.020]}\end{array}$ & $\begin{array}{c}{[0.117]} \\
-0.011 \\
{[0.015]}\end{array}$ & $\begin{array}{l}{[0.044]} \\
-0.005 \\
{[0.034]}\end{array}$ & $\begin{array}{c}{[0.039]} \\
0.068 \\
{[0.042]}\end{array}$ & $\begin{array}{c}{[0.023]} \\
-0.030 \\
{[0.025]}\end{array}$ & $\begin{array}{l}{[0.095]} \\
0.036^{*} \\
{[0.021]}\end{array}$ & $\begin{array}{c}{[0.151]} \\
-0.017 \\
{[0.083]}\end{array}$ & $\begin{array}{l}{[0.120]} \\
-0.047 \\
{[0.062]}\end{array}$ & $\begin{array}{c}{[2.323]} \\
1.299 \\
{[1.759]}\end{array}$ \\
\hline $\begin{array}{l}\text { R-squared } \\
\mathrm{H} 0: \alpha_{1}+\alpha_{2}=0 \text { (P-value) }\end{array}$ & $\begin{array}{l}0.214 \\
0.934\end{array}$ & $\begin{array}{l}0.103 \\
0.348\end{array}$ & $\begin{array}{l}0.121 \\
0.708\end{array}$ & $\begin{array}{l}0.092 \\
0.946\end{array}$ & $\begin{array}{l}0.016 \\
0.530\end{array}$ & $\begin{array}{l}0.002 \\
0.311\end{array}$ & $\begin{array}{l}0.076 \\
0.372\end{array}$ & $\begin{array}{l}0.045 \\
0.030\end{array}$ & $\begin{array}{l}0.044 \\
0.382\end{array}$ & $\begin{array}{l}0.065 \\
0.589\end{array}$ & $\begin{array}{l}0.015 \\
0.227\end{array}$ & $\begin{array}{l}0.015 \\
0.230\end{array}$ & $\begin{array}{l}0.024 \\
0.326\end{array}$ \\
\hline \multicolumn{14}{|l|}{ Panel B: OLS Estimates } \\
\hline Martyrs $\times$ female & $\begin{array}{c}-0.003 \\
{[0.017]}\end{array}$ & $\begin{array}{c}-0.001 \\
{[0.011]}\end{array}$ & $\begin{array}{c}-0.003 \\
{[0.018]}\end{array}$ & $\begin{array}{c}-0.008 \\
{[0.011]}\end{array}$ & $\begin{array}{c}-0.008 \\
{[0.009]}\end{array}$ & $\begin{array}{c}0.020 \\
{[0.027]}\end{array}$ & $\begin{array}{l}-0.001 \\
{[0.011]}\end{array}$ & $\begin{array}{c}-0.002 \\
{[0.008]}\end{array}$ & $\begin{array}{c}-0.011 \\
{[0.006]}\end{array}$ & $\begin{array}{c}0.007 \\
{[0.020]}\end{array}$ & $\begin{array}{c}0.018 \\
{[0.037]}\end{array}$ & $\begin{array}{c}0.001 \\
{[0.024]}\end{array}$ & $\begin{array}{c}-0.041 \\
{[0.731]}\end{array}$ \\
\hline Martyrs & $\begin{array}{l}0.020^{* *} \\
{[0.009]}\end{array}$ & $\begin{array}{c}0.003 \\
{[0.004]}\end{array}$ & $\begin{array}{l}0.017^{* *} \\
{[0.007]}\end{array}$ & $\begin{array}{c}0.007 \\
{[0.008]}\end{array}$ & $\begin{array}{c}0.007 \\
{[0.008]}\end{array}$ & $\begin{array}{c}0.003 \\
{[0.003]}\end{array}$ & $\begin{array}{l}-0.001 \\
{[0.009]}\end{array}$ & $\begin{array}{c}0.003 \\
{[0.007]}\end{array}$ & $\begin{array}{c}0.007 \\
{[0.006]}\end{array}$ & $\begin{array}{c}0.010 \\
{[0.007]}\end{array}$ & $\begin{array}{c}0.009 \\
{[0.030]}\end{array}$ & $\begin{array}{c}0.014 \\
{[0.018]}\end{array}$ & $\begin{array}{c}0.451 \\
{[0.464]}\end{array}$ \\
\hline R-squared & 0.214 & 0.108 & 0.122 & 0.095 & 0.019 & 0.012 & 0.077 & 0.057 & 0.050 & 0.067 & 0.028 & 0.037 & 0.050 \\
\hline $\mathrm{H} 0: \alpha_{1}+\alpha_{2}=0$ (P-value) & 0.371 & 0.846 & 0.389 & 0.766 & 0.777 & 0.416 & 0.519 & 0.839 & 0.391 & 0.321 & 0.363 & 0.555 & 0.434 \\
\hline Observations & 6,085 & 6,085 & 6,085 & 6,085 & 6,085 & 6,085 & 4,419 & 4,419 & 6,066 & 6,066 & 1,517 & 1,517 & 1,517 \\
\hline Individual Controls & YES & YES & YES & YES & YES & YES & YES & YES & YES & YES & YES & YES & YES \\
\hline Household Controls & YES & YES & YES & YES & YES & YES & YES & YES & YES & YES & YES & YES & YES \\
\hline Pre-revolution gov. controls & YES & YES & YES & YES & YES & YES & YES & YES & YES & YES & YES & YES & YES \\
\hline
\end{tabular}

Notes. Each cell represents a coefficient estimate using IV regression in Panel A, where the distance to the capital Cairo and the distance to the capital Cairo interacted with a female dummy are used to instrument the number of "martyrs" by governorate and the interaction term between the number of "martyrs" by governorate and the female dummy, and OLS regression in Panel B. The number of "martyrs" represents the number of fatalities from the $25^{\text {th }}$ of January 2011 to the end of June 2012, by governorate and is expressed in hundreds. A female dummy is included which results from first-differencing our equation in level (from the interaction term between female and 2012 in Equation 1). The dependent variable and all control variables are first-differenced. Labor force participation, unemployment and employment are defined according to the current work status. The reference period for the labor market information is 3 months. The labor force includes all those who are engaged in economic activity for purposes of market exchange and excludes subsistence workers, following the market definition of economic activity (see ILO, 1982). Wage work, employer, self-employed and unpaid family work are defined according to the current work status in primary job, reference period 3 following the market definition of economic activity (see ILO, 1982). Wage work, employer, self-employed and unpaid family work are defined according to the current work status in primary job, reference period 3 months. Informal sector employment is defined as having neither a legal work contract nor social security in primary job, reference period 3 months, whereas, formal sector employment is defined as having a legal work contract and social security in primary job, reference period 3 months. Private and public sector employment are defined according to the economic sector of primary job, reference period 3 months. Monthly and hourly wages are calculated in constant 1998 Egyptian Pounds and refer to the monthly/hourly wage in primary job, conditional on being employed, in log specification. The hours of work refer to the current number of work
hours per week, excluding subsistence work (market definition of economic activity) and conditional on being employed. Individual controls include the following variables in first-difference: a dummy variable for everhours per week, excluding subsistence work (market definition of economic activity) and conditional on being employed. Individual controls include the following variables in first-difference: a dummy variable for evermarried status, three dummies for educational attainment: primary and preparatory education, secondary education (either general or vocational) and above secondary education (either post-secondary institute or university education and above). The reference category is no educational degree (either illiterate or literate without any diploma). Household controls include the following variables in first difference: a rural dummy, an indicator for male headed household, household size, the number of adults aged 15 to 64 years old, an indicator for the head's marital status being single and three dummies for the head of the household's educational attainment. per 10,000 inhabitants, the average number of years of schooling for individuals aged 15-30 by governorate in 2006, the population density by governorate in 2006, the natural log of GDP per capita by governorate in 2005/2006 and a dummy variable for fully urban governorates (Cairo, Alexandria, Suez and Port Said). ${ }^{* * *} \mathrm{p}<0.01,{ }^{* *} \mathrm{p}<0.05,{ }^{*} \mathrm{p}<0.1$. Robust standard errors in brackets are clustered at the governorate level. The table also reports the $p$-value of a test with null hypothesis $\alpha_{1}+\alpha_{2}=0$ to check whether the protests significantly affect women's outcomes of interest. 


\section{Appendix}

In Online Appendix Figure 1, we present an example of the Statistical Database of the Egyptian Revolution screenshot. The dataset covers wide-range information on the classification of the incident, type of incident, date, governorate of the incident, name of the person, site of the incident, cause of death, occupation, place of residence, marital status, name of the hospital, date of birth, date of death and incident report number. In the note below the figure, we provide for example purposes the translation of the description of one of the events.

In Online Appendix Figure 2, we present a map of labor force participation rates in 2006. The figure does not show a strong correlation between labor force participation rates and the distance to the capital Cairo City, as opposed to the clear correlation between the latter and the governorate level number of "martyrs" in Figure 2.

In Online Appendix Table 1, we summarize Egyptian governorate characteristics by the intensity of the protests. We check whether governorates with above median number of "martyrs" differ along a number of pre-revolution characteristics from governorates with below median number of "martyrs". Governorates exposed to a higher intensity of protests have a higher share of public sector employment and are more likely to be urban, compared to governorates exposed to a lower intensity of protests. Apart from these two characteristics, the two groups do not have any significant differences along the other dimensions such as population density, real GDP per capita, average number of years of schooling for the youth population and number of police stations. In the regressions analysis, we control for potential differences in governorates' characteristics by conditioning on the pre-revolution values of these variables. Conditioning on pre-treatment variables is a standard approach in the estimation of Difference-in-Differences specifications.

In Online Appendix Table 2, we present coefficient estimates from a governorate level regression, where we regress the governorate level number of "martyrs" on a set of prerevolution governorate characteristics. All coefficient estimates are not statistically different from zero, which means that governorates exposed to different intensities of the protests are not significantly different along a set of pre-revolution governorate characteristics. Interestingly, we find a negative correlation between the governorate level number of "martyrs" and the number of police stations per 10,000 inhabitants. This correlation may suggest that the number of "martyrs" represents as well a proxy for the participation in demonstrations (the presence of police stations deterring the participation in protest activities) rather than just being a proxy for political repression.

In Online Appendix Table 3, we investigate the heterogeneity of the effects of the Egyptian protests on labor force participation, focusing on differences in household income and individuals' educational attainment. The table reports IV estimates where we split the sample by quartiles of the pre-revolution per capita household income distribution and by educational attainment (four educational categories) ${ }^{27}$. We only find an increase in labor force participation for women who belong to the two lowest quartiles of the sample distribution of pre-revolution per capita household income and women with secondary education.

In Online Appendix Table 4, we investigate the heterogeneity of the effects of the Egyptian uprisings on individuals' labor market outcomes, by religious group. Results concerning Christian working-aged individuals should be considered with caution because the sample size is small and the instruments are weakly correlated with the endogenous regressors (see the

\footnotetext{
${ }^{27}$ We consider the following four educational categories: no educational degree (either illiterate or literate without any diploma), primary and preparatory education, secondary education (either general or vocational), and above secondary education (either post-secondary institute or university education and above).
} 
value of the Kleibergen-Paap rk Wald Test). Our results on the subsample of Muslim individuals are consistent with the findings we have presented on the whole estimation sample.

Online Appendix Table 5 shows results from a regression in which the dependent variables are monthly wages, hourly wages or number of weekly working hours, and the main explanatory variable is an interaction term between the "martyrs" variable and a dummy equal to 1 if the individual is employed in the private sector in 2006 (0 otherwise). These regressions confirm a reduction in the number of hours worked per week for people employed in the private sector (see test of statistical significance of the sum $\alpha_{1}+\alpha_{2}$ ).

Online Appendix Table 6 presents the correlation between women's labor force participation (dependent variable) and their husband's wage and its variance. Coefficients are from OLS estimates, conditional on individual, household and pre-revolution governorate controls.

In Online Appendix Table 7, using information from the ELMPS 2006 we present descriptive statistics on the hourly wages (in Egyptian Pounds) of men and women for different levels of educational attainment: no educational degree (either illiterate or literate without any diploma), primary and preparatory education, secondary education (either general or vocational) and above secondary education (either post-secondary institute or university education and above). On average, men earn more in terms of hourly wages compared to women for the lowest level of educational attainment (no educational degree). Instead, women with secondary or above secondary education have higher hourly wages compared to men. This is in line with Said (2007), who analyzes the trends in real hourly and monthly wages, under the period of the Economic Reform and Structural Adjustment Program. She finds that the relative rewards of women have significantly improved between 1998 and 2006, as they witnessed larger wage improvements compared to their male peers (mostly because a larger share of women is employed in the public sector, which witnessed a higher increase in wages compared to the private sector). Even after accounting for differences in characteristics amongst workers, she still finds that the gender pay gap has narrowed down and turned into a wage premium in favor of women employed in the public sector.

In Online Appendix Table 8, we have checked whether the 2011 protests are reducing the gender gap in children's education. We restrict our sample to children's aged 6 to 15 years old and study the effect of political unrest on the probability of going to school at the time of the survey, as well as on the probability of going to a religious school (Azhari), conditional and unconditional on studying at the time of the survey. We do not find any evidence on a differential effect of the revolution on children's education by gender. The protests do not seem to have an impact on the investment in children's human capital.

In Online Appendix Table 9, we report descriptive statistics on the spatial distribution of the "martyrs" during the 2011 Egyptian revolution, for the first eighteen days of the revolution and for the subsequent period, from the $12^{\text {th }}$ of February 2011 till the end of June 2012, after Mubarak stepped down and the Supreme Council of the Armed Forces (SCAF) took power in Egypt in the name of the military.

For sake of comparison with our parsimonious specification (i.e., the first-difference transformation, see Equation 2), in Online Appendix Table 10 we estimate our Difference-inDifferences equation in levels (Equation 1), using the OLS estimator. We condition on a similar set of control variables and include individual, governorate and year fixed effects. The two main coefficients of interest are $\alpha_{1}$, the coefficient estimate of the interaction term between the governorate level number of "martyrs," the year dummy and the female dummy, and $\alpha_{2}$, the coefficient estimate of the interaction term between the governorate level of "martyrs" and the year dummy. We find that the differential effect of the protests by gender $\left(\alpha_{1}\right)$ is positive and statistically different from zero, in line with our parsimonious specification, Equation 2, that is the first-difference transformation. 
Since Equation 2 is a first difference transformation of Equation 1, some outcomes of interest are categorical variables taking the values $-1,0,1$ (after first differencing dummy variables like labor force participation, employment and unemployment). We have also estimated Equation (2) using IV ordered probit model (see Online Appendix Table 11). In particular, we fit an observed recursive mixed process model, using the cmp command in STATA developed by Roodman (2011), where the governorate level number of "martyrs" and its interaction term with the female dummy are considered as endogenous and are instrumented by the distance to the capital Cairo and the distance to the capital Cairo interacted with the female dummy. The table reports the marginal effects for each category (-1), (0) and (1). The IV-ordered probit estimations are highly consistent with the 2SLS estimations presented in Section 5.1. The category (-1) refers to individuals who participated in the Egyptian labor market in 2006, but not in 2012. The category (0) refers to individuals who did not change their labor force participation between the two years: either individuals participated in 2006 and 2012, or they did not participate in the labor force in those two years. The category (1) refers to individuals who participated in 2012 and not in 2006. In line with the 2SLS estimations presented above, we find that the differential effect of the protests by gender $\left(\alpha_{1}\right)$ is positive and statistically different from zero for the (1) category. Instead, we find a negative and significant estimated coefficient for the $(-1)$ category, which suggests that the protests reduce the probability of a woman to participate in the labor market in 2006 and not in 2012, compared to their male peers. We also find a positive and significant differential effect of the protests by gender, considering the (1) category. This finding implies that the protests reduce the gender gap in unemployment and employment. More precisely, the protests increase the probability of women being actively searching for employment in 2012 and not in 2006 by 5 percentage points and increase employment by 3 percentage points, when the effect is computed using a 1-standard deviation increase in the intensity of the protests measure.

In Online Appendix Table 12, we investigate the effect of the protests on labor force participation, unemployment and employment, using a sample of couples only. To be included in the estimation sample of these regressions, the head of the household and his/her spouse need to be married in the two waves, 2006 and 2012, and need to be in the working age category (15-64 years old). We find results similar to those with an estimation sample of all working age men and women. The protests reduce the gender gap in labor market outcomes. Women are 11 percentage points more likely to participate in the Egyptian labor market, 4 percentage points more likely to actively search for employment and 7 percentage points more likely to be employed, when the effects are computed considering a 1-standard deviation increase in the intensity of the protests. The sum of the two estimated coefficients $\alpha_{1}+\alpha_{2}$ is statistically different from zero (see in Online Appendix Table 12 the test with null hypothesis $\alpha_{1}+\alpha_{2}=0$ ).

In Online Appendix Table 13, we investigate the effect of the protests on women's decision making. The sample only includes married working age women in male-headed households. We consider a set of questions reflecting the decision-making process within the household. Women, who are currently married, were asked about the family member who has the final say regarding a set of decision-making questions. Our indicator for decision-making takes the value 1 if the woman participates in the decision either alone or with other household members. For instance, a woman can take a decision alone, jointly with her husband or with her husband and in-laws and similarly, for men. Whereas, the indicator takes the value zero, if the individual did not participate at all in the decision-making process. The decision-making questions covered the following aspects: making large household purchases, making household purchases for daily needs, visits to family, friends or relatives, food cooked each day, getting medical treatment or advice for herself, buying clothes for herself, taking child to the doctor, dealing with children's school and teachers, sending children to school on a daily basis and buying clothes or other needs for children. The answers to these questions are, to some extent, 
subjective. Importantly, they also cover a wide-range of domestic chores rather than reflecting women's empowerment. We find a reduction in women's decision-making regarding household purchases for daily needs, visits to family, friends and relatives, and getting medical treatment. Women are less likely to take their children to the doctor or to send their children to school on a daily basis. We also find that women are more likely to deal with children's school and teachers, and to buy clothes and other needs for their children, although, for these decisions, we do not find any differential effect of the protests by gender. Overall, this table confirms that changes in social norms do not represent the main mechanism explaining the increase in female labor force participation.

In Online Appendix Table 14, we investigate the effect of the protests on labor force participation, unemployment and employment using the number of male "martyrs" (Panel A) and the number of female "martyrs" (Panel B). The results from the sets of regressions in both panels are consistent to our previous findings. The protests lead to an increase in women's labor force participation, as well to an increase in the probability of women's actively searching for employment.

Online Appendix Table 15 shows that our results are robust to the use of the number of "martyrs" normalized by the governorate's population size, as measure of the intensity of the protests.

In Online Appendix Table 16, we consider a sample of prime-aged individuals (individuals aged at least 21 years old in 2006 to 64 years old in 2012), to make sure that our results are not driven by sample aging between the two waves 2006 and 2012. This table confirms the reduction in the gender gap in labor force participation, unemployment and employment. The magnitude of the estimated coefficients is smaller than in Table 4.

In Online Appendix Table 17, we investigate the effect of the protests on different types of employment by distinguishing between wage work, employer/self-employment and unpaid family work, using OLS and IV regressions. Estimates do not show any significant effect of the protests on women's wage work or on the probability of being employer/ self-employed, as we fail to reject the null hypothesis that the sum of the two estimated coefficients $\left(\alpha_{1}+\alpha_{2}\right)$ is statistically different from zero. However, we find a statistically significant effect of the revolution on unpaid family work for women. The protests increase the probability of being an unpaid family worker for women by 14 percentage points, when we compute the effect considering a 1-standard deviation increase in the intensity of the protests. Egyptian women increase their time devoted to home production, while also actively searching for paid employment. By contrast, we find that the 2011 protests have reduced men's wage work and have pushed men to engage in non-wage work, such as being employer or self-employed. A 1standard deviation increase in protests' intensity has led to a reduction in men's wage work by 10 percentage points, whereas men witness a 7 percentage points increase in the probability of being either employers or self-employed.

In Online Appendix Table 18, we estimate the impact of the protests by distinguishing between formal and informal sector employment, using OLS and IV regressions. The informal sector in Egypt, like in other MENA countries undergoing structural and economic reforms, has played a major role in employment, especially in periods of economic adjustment and transition (Wahba, 2009). We find that the differential effect of the protests by gender on informal and formal sector employment is statistically significant. However, the sum of the two estimated coefficients $\alpha_{1}$ and $\alpha_{2}$ is not statistically different from zero (see in Online Appendix Table 18 the test with null hypothesis $\alpha_{1}+\alpha_{2}=0$ ). 


\section{Online Appendix Figure 1: Dataset on the "Martyrs" of the Egyptian Revolution}

\begin{tabular}{|c|c|c|c|c|c|c|c|c|c|c|c|c|}
\hline N & us & & $\mathrm{k}$ & & 1 & & 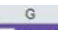 & $r$ & D & c & B & $A$ \\
\hline 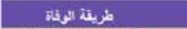 & مكان الهاتعة & Fo & 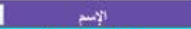 & F & الهانقة & & العبار & 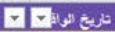 & & $\nabla$ & تصني الواتعة & $\nabla$ \\
\hline مثل كازي اسقل الغط & بيدان التحرير & 17 & 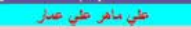 & & لتض أفصلم 8 أبريل & 1 & الثاهرة & $104 / 09 / 2011$ & لقض استصام باكلثرة & 1 & أشات سيلية & \\
\hline 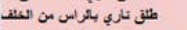 & ميط السفارة الإسرانيلية ـ الجيزة & 22 & عافث بحي ابراهي & & 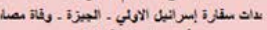 & 1 & الجيزن & 1 16/05/2011 & 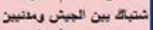 & 2 & أشدات سيانية & 2 \\
\hline جرع يقراس الدي المي نزيل دثر & 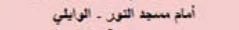 & 23 & 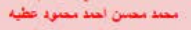 & 1 & أنداث العبلية المبلى & 1 & لثاشرن & $123 / 07 / 2011$ & انشيكات أمشية & 3 & أنداث سيانية & 3 \\
\hline طنق تزري باترس & كويري جاعة القاهرة & & رج ربضان حسين يهي & 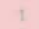 & أحداث سقارة إسرائيل الثنية . الجيزة & 1 & تجيزن & 1 09/09/2011 & ك ك بين الجيض بشنييز & 4 & أشداث سيلبية & 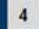 \\
\hline الرية قلية & ميط السقارة الإسرانيلية ـ لبيزة & & رضا سع الثين بذبن & 2 & أسداث سلارن إبراتيل الثابية ـ البيزة & 2 & "لبيزة: & 2 09/09/2011 & 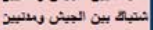 & 5 & أسداث سيانية & 5 \\
\hline 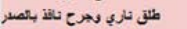 & حيط اسقارة الإسرانيلية ـ الجيزة & & ملاء راض سيلينان سأد & 3 & أدداث سفارة إبرانيل الثئية ـ الجيزة & 3 & "ليززة & 3 09/09/2011 & نقبك بين الجين مشئيز & 6 & أعداث سياسية & \\
\hline 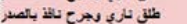 & ميط اسفارة الإسر تيلية ـ البيزة & & مصطفي حيب حسن نسات & 4 & أهداث سقارة إبر الثيل الثيلية ـ البيزة & 4 & "كيزة" & 4 09/09/2011 & 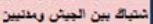 & 7 & أندات سياسية & 7 \\
\hline נה & سبي بيثي مانسبير - بولاق نيو العلا & 25 & اسلس نتخي عزيز & 1 & أدداث مستسير 01 ـ لثقاهرة & 1 & الثادرة & 1 10/09/2011 & نتيكاك بين البيث بمنتيز & 8 & نداث سياسية & 8 \\
\hline طلق ثازي باكه & 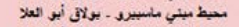 & 28 & السن ليزاد اسين & 2 & أداث بانسير 02 ـ الثارة & 2 & القابرة & 2 10/09/2011 & نتباك بين البين مبنتير & 9 & أساث سيخبية & 9 \\
\hline נמה & 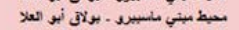 & 39 & ايهن صنير بشاي & 3 & أدياث مانسيرد 03 ـ الثاشرة & 3 & الثارية & & نيفيك بين الجيث بمنتيز & 10 & أسداث سينية & 10 \\
\hline مثل كازي بكيطن & مبط سيلي ماسيبرد - بولاق نيو العلا & 36 & اين تصبي ربي & 4 & أسداث ماسيسير 04 ـ لثأرنا & 4 & الثامرة & $410 / 09 / 2011$ & تفبه بين البين بندنيز & 11 & أشاث سياسية & 11 \\
\hline נAn & سبط ميتي ماسيبير - بولاق أيو العلا & 30 & هرجس رادي راضي & 5 & نداث ماسيسي 05 ـ لثقارة & 6. & لثاهرة & 5 10/09/2011 & اليقاك بين الجين بمنتيز & 12 & أداك سياسية & 12 \\
\hline נגט & 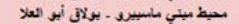 & 47 & جيل فيل نينين & 6 & أدذاث ماسيبر 06 ـ لثأرة & 6 & (ثأهرة & 6 10/09/2011 & تمبيك بين الجيثن بمنتير & 13 & أسداث سيلين & 13 \\
\hline كسون נהردع تطفية & 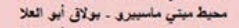 & 24 & رستي بكزي لني جرجس & $?$ & نداث مانسيرد 07 ـ الثقارة & 7 & لاتشرة & 7 10/09/2011 & ثتبك بين الجيث بشنييز & 14 & أشداث سيلبية & 14 \\
\hline הد & 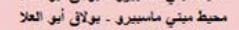 & 29 & سلنع جريص فتري & 8 & 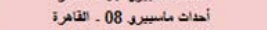 & 8 & |لثابرة & 8 10/09/2011 & 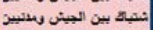 & 15 & أدثاث سيانبية & 15 \\
\hline مثل ناري باتيطن & ميط سيتي ماسبيرد - بولاق نيو العلا & 46 & نشعاته تيت خشبي موضر & 9 & أدياث ماسبيرد 09 - الثاهرة & 9 & الثابرة & 9 10/09/2011 & نشيك بين البيثن بمنتيز & 16 & أساث سيانية & 16 \\
\hline دهن & سيط بيلي مانسيري - يولاق أيو العلا & 28 & شتويد نصي صي & 1 & أدهاث باسبير 10 ـ لثادرة & 10 & الثأهرة & 10 10/09/2011 & نقياح بين البيش بمنييز & 17 & أسدات سياسي & 17 \\
\hline 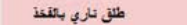 & سيط مبتي بانسيبر - بولوق نيو العلا & 26 & صيجي جال نطب جـ له & 11 & أحداث ماسييرد 11 ـ ثقاشرة & 11 & الثاهرة & 1110 & نتيتاك بين الجيثن بمنتيز & 18 & أسداث سيانية & 18 \\
\hline בהט & 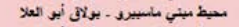 & 45 & سي يراشي رنف جرج & 12 & أسداث ماسبيرد 12 - لثاثرة & 12 & الثاشرة & & 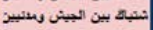 & 19 & انسات سياني & 19 \\
\hline נدט & 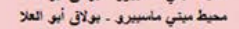 & 40 & "ارس شلف يوي & 1. & أدداث مانسير 13 ـ الثادرة & 13 & 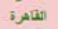 & 131 & نقياك بين الجيثن مسنيز & 20 & أدداث سينية & 20 \\
\hline נגט & ميط سيني ماسيسير - بولاق أيو العلا & 26 & 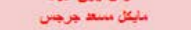 & 14 & أسداث مالسيبرد 14 ـ للأهرة & 14 & الثأرة: & 1410 & نمبيك بين اليبين مينتيز & 21 & أنداث سيانية & 21 \\
\hline נגט & 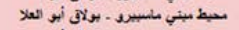 & 40 & 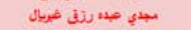 & 1 & كدات مانسير 15 ـ لقاهرة & 15 & الثادرة & 151 & باك بين الجيثن بستيز & 22 & أشداث سيلم & 22 \\
\hline بر مضفم & سيط سيني ماسيبر - بوناق أيو العلا & & جبلي سير سيب & 16 & أسداث ماسبيرد 16 - لثاهرة & $16 \mathrm{C}$ & لألمرة & 161 & خباله بين البين سبنسيز & 23 & أشيات سباس & 23 \\
\hline נמט & مبط سيتي ماسيبر - بولاق نيو العلا & 55 & 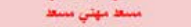 & 17 & 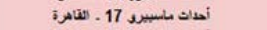 & & (تلامرة & 171 & نشبيك بين البيثن بشنييز & 24 & أكداث سيابت & 24 \\
\hline בגנט & سيط بيلي ماسبيرد - بولاق نيو العلا & 37 & 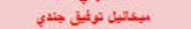 & 18 & أديات ماسيسير 18 ـ الثاشرة & 18 & |ثلاشرة & & نتيك بين البيثن مينسير & 25 & أسات سبينب & 25 \\
\hline مثل ثازي باتصسر & 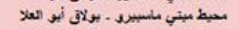 & 20 & بيتا إيراهي دانيك & 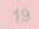 & أداث مانسيرد 19 ـ لقاشرة & 19 & كلاشرة & 191 & نقياك بين البيثن مسنتيز & 26 & أسداث سيلسية & 26 \\
\hline המה & 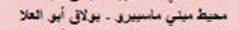 & 26 & يمد راجي تصيف & 3 & أسدات باسيبر 20 ـ القاشرة & 20 & لثامرة & 201 & نتيكا بين البين بشنييز & 27 & أسات س & 27 \\
\hline مثل ناري باتطر & مبط بيتي ماسيبرد - بولاق أيو العلا & 23 & فواد سطي & 2 & نداث ماسيير 21 - لتأرة & & القامر3 & 211 & 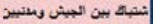 & 28 & أشات & 28 \\
\hline 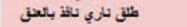 & 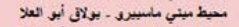 & 37 & رائل بيديل شيل & $=$ & أداث ماسبير 22 ـ لثادرة & & لثاهرة & 221 & نثبا بين البين ربنتيز & 29 & أسات سيلبية & 29 \\
\hline & محيط سيتي ماسبير - بونأ أيو العلا & 23 & بيتر عقل & 24 & أدداث ماسبير 23 ـ لثقاهرة & & التاشرة & & لثباك بين الجيثن بمنتيز & 30 & أسداث سيلبية & 30 \\
\hline طقل ثاري & 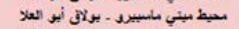 & & بـر & 2 & أحداث ماسيير 24 ـ الثاهرة & & الثاهرة & 241 & ثنباك بين البين مبنسيز & 31 & أشيات سياسية & 31 \\
\hline ثير مطفم & 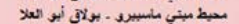 & & 4 & 2 & 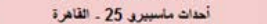 & & الثادرة & 251 & 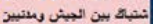 & 32 & أسداث س & 32 \\
\hline دهن & سيط بيثي مانسيبر - بولاق أبي العلا & & ميهول اتهيه & 26 & أدداث ماسبير 26 ـ لثاشرة & & ثرة & 261 & شتبية & 33 & أشدات & 33 \\
\hline ده & 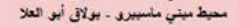 & 66 & مجاي نهي مست & 4 & 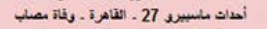 & 27 & الثاهرة & 271 & شنتيك بين الجيثن بمنتيز & 34 & أسدات سيسي & 34 \\
\hline مثل شاري باكسر & شارع سعد حسهي & & 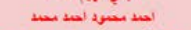 & 1 & أدهاث سحد سمهر 01 ـ القاهرة & & الثادرة & 11 & انثبا بين أن نسنيين & 35 & أشداث سينيب & 35 \\
\hline مثل تاري بكراس & شارع محس محهي & 24 & لمطتي معد حي التعم صصير & 2 & 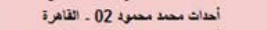 & & 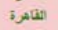 & 21 & انقبك بين أنم رسنتين & 36 & أنداث سباس & 36 \\
\hline ل مثل ثلري & شارع تحد محسد & 33 & هازم نشيوت محس ايرايه & 3 & أزداث سحد مد & & هر: & & $x \rightarrow$ & & أنداث سياس & \\
\hline 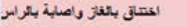 & شارع تحد مسهد & 26 & سان مشير خيقة & 4 & أكداث محد مسهد 04 ـ القاشرة & & القاشرة & 22 & انتيك بين أن وبشتيين & 38 & أندات سيلس & 38 \\
\hline 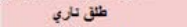 & شارع حسد شحو2 & 19 & 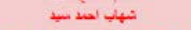 & s & أهداث سحد مسر2 05 ـ القاهرة & & الثاهرة & $320 / 11 / 2011$ & انتيك بين أن وبنيسن & 39 & أسدات سيخية & 39 \\
\hline 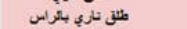 & شارع تحد محسو & 25 & نهيب الثين أمب أبرابي ثل & 6 & أدداث محد محهد 06 ـ الثاهرة & & (لقاهرة & $420 / 11 / 2011$ & انشبك بين أنت نسنتين & 40 & أسداث سيلية & 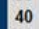 \\
\hline
\end{tabular}

Notes. Data source is the Statistical Database of the Egyptian Revolution. The dataset reads from the right to the left. The columns titles (in the first line) are the following: the classification of the incident, the type of the incident, the date of the incident, the governorate, the description of the incident, the name of the person, the site of death, the cause of death. The second line reads the following from the right to the left: Political event, breaking a sit-in by force, 04/09/2011, Cairo, breaking the sit-in of the $8^{\text {th }}$ of April, Name, Tahrir Square, gunshot at the bottom of the neck. Other variables available in the dataset are the following: the individual's occupation, place of residence, marital status, name of the hospital, date of birth, date of death and the incident report number.

Online Appendix Figure 2: Labor Force Participation by Governorate in 2006 (15-64 years old)

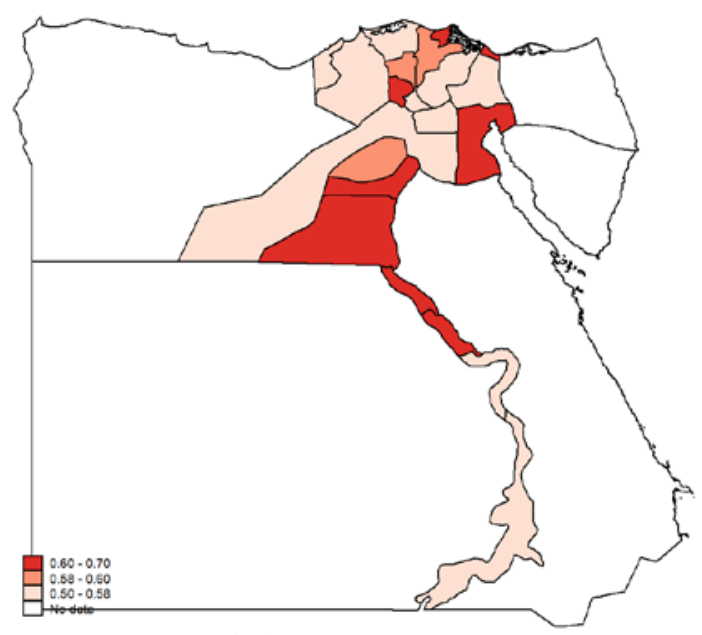

Notes: Data Source is the ELMPS 2006. 


\section{Online Appendix Table 1: Governorate Characteristics by Intensity of the Protests}

\begin{tabular}{lcc} 
& Low intensity & High intensity \\
\hline VARIABLES & Mean & Mean \\
\hline Share of public sector & 0.147 & $0.174^{*}$ \\
Number of police stations & 0.058 & 0.064 \\
Mean youth education & 10.190 & 10.460 \\
Population density & 0.512 & 1.118 \\
Log of real GDP per capita & 8.643 & 8.696 \\
Fully urban governorate & 0.000 & $0.364^{* *}$ \\
\hline
\end{tabular}

Notes. All variables are pre-revolution governorate controls and are reported for two groups of governorates based on the median number of “martyrs", from the $25^{\text {th }}$ of January 2011 to the end of June 2012. The median number of “martyrs", fatalities during the Egyptian revolution, is 23 "martyrs". Low intensity are the governorates witnessing a number of "martyrs" below the median, while high intensity refers to governorates witnessing a number of "martyrs" above the median. Governorate characteristics are the following: the share of public sector employment by governorate in 2006, the number of police stations by governorate per 10,000 inhabitants, the average number of years of schooling for individuals aged 15-30 by governorate in 2006, the population density by governorate in 2006, the natural log of GDP per capita by governorate in 2005/2006 and a dummy variable for fully urban governorates (Cairo, Alexandria, Suez and Port Said). $* * *$ p $<0.01$, $* *$ $\mathrm{p}<0.05, * \mathrm{p}<0.1$. Means of these variables are reported for governorates with a number of "martyrs" below the median and governorates with a number of "martyrs" above the median. A t-test is performed to test the equality of the mean between the two groups of governorates.

\section{Online Appendix Table 2: Predicting the Number of "Martyrs" Using Pre-Revolution Governorate Controls}

\begin{tabular}{lc} 
VARIABLES & Martyrs \\
\hline Share of public sector & 12.519 \\
& {$[10.627]$} \\
Number of police stations & -20.974 \\
& {$[14.380]$} \\
Mean youth education & 0.341 \\
& {$[0.441]$} \\
Population density & 0.084 \\
& {$[0.119]$} \\
Log of real GDP/capita & -2.177 \\
& {$[1.767]$} \\
Fully urban governorate & 1.853 \\
Observations & {$[1.183]$} \\
R-squared & 22 \\
\hline
\end{tabular}

Notes. Each cell represents a coefficient estimate using OLS regression. The dependent variable represents the number of fatalities from the 25th of January 2011 to the end of June 2012, by governorate and is expressed in hundreds. ${ }^{* * *} \mathrm{p}<0.01,{ }^{* *} \mathrm{p}<0.05,{ }^{*} \mathrm{p}<0.1$. Robust standard errors are in brackets. The pre-revolution governorate characteristics are the following: the share of public sector employment by governorate in 2006, the number of police stations by governorate per 10,000 inhabitants, the average number of years of schooling for individuals aged $15-30$ by governorate in 2006, the population density by governorate in 2006, the natural log of GDP per capita by governorate in 2005/2006 and a dummy variable for fully urban governorates (Cairo, Alexandria, Suez and Port Said). 
Online Appendix Table 3: Labor Force Participation Decision

\begin{tabular}{|c|c|c|c|c|}
\hline \multicolumn{5}{|c|}{ Panel A: By sample distribution of per capita household income } \\
\hline VARIABLES & $\begin{array}{c}\text { (1) } \\
\text { 1st quartile }\end{array}$ & $\begin{array}{c}(2) \\
\text { 2nd quartile } \\
\end{array}$ & $\begin{array}{c}\text { (3) } \\
\text { 3rd quartile } \\
\end{array}$ & $\begin{array}{c}\text { (4) } \\
\text { 4th quartile }\end{array}$ \\
\hline Martyrs $\times$ female & $\begin{array}{c}0.133^{* *} \\
{[0.053]}\end{array}$ & $\begin{array}{c}0.232 * * * \\
{[0.089]}\end{array}$ & $\begin{array}{c}0.089 \\
{[0.064]}\end{array}$ & $\begin{array}{c}0.047 \\
{[0.040]}\end{array}$ \\
\hline Martyrs & $\begin{array}{c}-0.027 \\
{[0.027]}\end{array}$ & $\begin{array}{l}-0.026 \\
{[0.042]}\end{array}$ & $\begin{array}{c}-0.001 \\
{[0.027]}\end{array}$ & $\begin{array}{c}-0.015 \\
{[0.019]}\end{array}$ \\
\hline Observations & 5,147 & 2,939 & 2,935 & 3,014 \\
\hline R-squared & 0.129 & 0.093 & 0.125 & 0.213 \\
\hline Individual Controls & YES & YES & YES & YES \\
\hline Household Controls & YES & YES & YES & YES \\
\hline Pre-revolution Governorate Controls & YES & YES & YES & YES \\
\hline $\mathrm{H}_{0}: \alpha_{1}+\alpha_{2}=0$ (P-value) & 0.025 & 0.008 & 0.094 & 0.353 \\
\hline Kleibergen-Paap rk Wald F statistic & 24.34 & 14.686 & 37.527 & 30.307 \\
\hline \multicolumn{5}{|l|}{ Panel B: By educational attainment } \\
\hline VARIABLES & $\begin{array}{c}(1) \\
\text { No educ. }\end{array}$ & $\begin{array}{c}(2) \\
\text { Prim/Prep } \\
\end{array}$ & $\begin{array}{c}\text { (3) } \\
\text { Secondary }\end{array}$ & $\begin{array}{c}\text { (4) } \\
\text { Above sec. }\end{array}$ \\
\hline Martyrs $\times$ female & $\begin{array}{c}0.150^{* *} \\
{[0.074]}\end{array}$ & $\begin{array}{c}0.095 * * \\
{[0.047]}\end{array}$ & $\begin{array}{c}0.198 * * * \\
{[0.054]}\end{array}$ & $\begin{array}{c}0.052 \\
{[0.048]}\end{array}$ \\
\hline Martyrs & $\begin{array}{c}-0.041 \\
{[0.032]}\end{array}$ & $\begin{array}{c}-0.021 \\
{[0.037]}\end{array}$ & $\begin{array}{c}-0.039 \\
{[0.025]}\end{array}$ & $\begin{array}{l}-0.006 \\
{[0.015]}\end{array}$ \\
\hline Observations & 4,426 & 2,704 & 4,751 & 2,154 \\
\hline R-squared & 0.031 & 0.210 & 0.177 & 0.027 \\
\hline Individual Controls & YES & YES & YES & YES \\
\hline Household Controls & YES & YES & YES & YES \\
\hline Pre-revolution Governorate Controls & YES & YES & YES & YES \\
\hline $\mathrm{H}_{0}: \alpha_{1}+\alpha_{2}=0$ (P-value) & 0.092 & 0.036 & 0.000 & 0.308 \\
\hline Kleibergen-Paap rk Wald F statistic & 17.598 & 39.145 & 32.361 & 32.086 \\
\hline
\end{tabular}

Notes. Each cell represents a coefficient estimate using IV regression, where the distance to the capital Cairo and the distance to the capital Cairo interacted with a female dummy are used to instrument the number of "martyrs" by governorate and the interaction term between the number of "martyrs" by governorate and the female dummy. The number of "martyrs" represents the number of fatalities from the $25^{\text {th }}$ of January 2011 to the end of June 2012, by governorate and is expressed in hundreds. A female dummy is included which results from firstdifferencing our equation in level (from the interaction term between female and 2012 in Equation 1). The dependent variable and all control variables are first-differenced. Labor force participation, unemployment and employment are defined according to the current work status. The reference period for the labor market information is 3 months. The labor force includes all those who are engaged in economic activity for purposes of market exchange and excludes subsistence workers, following the market definition of economic activity (see ILO, 1982). Individual controls include the following variables in first-difference: a dummy variable for ever-married status, three dummies for educational attainment (only included in Panel A): primary and preparatory education, secondary education (either general or vocational) and above secondary education (either post-secondary institute or university education and above). The reference category is no educational degree (either illiterate or literate without any diploma). Household controls include the following variables in first difference: a rural dummy, an indicator for male headed household, household size, the number of adults aged 15 to 64 years old, a dummy variable for land ownership, an indicator for the head's marital status being single and three dummies for the head of the household's educational attainment. Pre-revolution governorate controls include the following variables as well as their interaction terms with a female dummy: the share of public sector employment by governorate in 2006, the number of police stations by governorate per 10,000 inhabitants, the average number of years of schooling for individuals aged 15-30 by governorate in 2006, the population density by governorate in 2006, the natural log of GDP per capita by governorate in 2005/2006 and a dummy variable for fully urban governorates (Cairo, Alexandria, Suez and Port Said). *** p<0.01, ** $\mathrm{p}<0.05, * \mathrm{p}<0.1$. Robust standard errors in brackets are clustered at the community level. The reported Kleibergen-Paap rk Wald F-statistic corresponds to the first stage IV regression F-statistic. The Stock-Yogo weak identification test critical values are 7.03, 4.58, 3.95 and 3.63, at the $10 \%, 15 \%, 20 \%$ and $25 \%$ maximal IV size respectively. The table also reports the p-value of a test with null hypothesis $\alpha_{1}+\alpha_{2}=0$ to check whether the protests significantly affect women's outcomes of interest. 
Online Appendix Table 4: Labor Force Participation, Unemployment and Employment by Religious Group

\begin{tabular}{|c|c|c|c|c|c|c|}
\hline - & Labor For & articipation & Uner & ment & Em & nent \\
\hline VARIABLES & $\begin{array}{c}\text { (1) } \\
\text { IV } \\
\text { Muslims } \\
\end{array}$ & $\begin{array}{c}\text { (2) } \\
\text { IV } \\
\text { Christians } \\
\end{array}$ & $\begin{array}{c}\text { (3) } \\
\text { IV } \\
\text { Muslims } \\
\end{array}$ & $\begin{array}{c}\text { (4) } \\
\text { IV } \\
\text { Christians } \\
\end{array}$ & $\begin{array}{c}\text { (5) } \\
\text { IV } \\
\text { Muslims } \\
\end{array}$ & $\begin{array}{c}\text { (6) } \\
\text { IV } \\
\text { Christians } \\
\end{array}$ \\
\hline Martyrs $\times$ female & $\begin{array}{c}0.211 * * * \\
{[0.062]}\end{array}$ & $\begin{array}{c}-0.323 \\
{[0.328]}\end{array}$ & $\begin{array}{c}0.062 * * \\
{[0.029]}\end{array}$ & $\begin{array}{c}0.027 \\
{[0.122]}\end{array}$ & $\begin{array}{c}0.149 * * \\
{[0.058]}\end{array}$ & $\begin{array}{c}-0.350 \\
{[0.333]}\end{array}$ \\
\hline Martyrs & $\begin{array}{c}0.005 \\
{[0.019]}\end{array}$ & $\begin{array}{c}0.250 \\
{[0.170]}\end{array}$ & $\begin{array}{c}0.009 \\
{[0.014]}\end{array}$ & $\begin{array}{c}0.032 \\
{[0.070]}\end{array}$ & $\begin{array}{c}-0.004 \\
{[0.021]}\end{array}$ & $\begin{array}{c}0.217 \\
{[0.163]}\end{array}$ \\
\hline Observations & 6,564 & 482 & 6,564 & 482 & 6,564 & 482 \\
\hline R-squared & 0.027 & 0.107 & 0.015 & 0.112 & 0.069 & 0.102 \\
\hline Individual Controls & YES & YES & YES & YES & YES & YES \\
\hline Household Controls & YES & YES & YES & YES & YES & YES \\
\hline Pre-revolution Governorate Controls & YES & YES & YES & YES & YES & YES \\
\hline $\mathrm{H}_{0}: \alpha_{1}+\alpha_{2}=0$ (P-value) & 0.001 & 0.730 & 0.008 & 0.553 & 0.007 & 0.520 \\
\hline Kleibergen-Paap rk Wald F statistic & 26.761 & 2.587 & 26.761 & 2.587 & 26.761 & 2.587 \\
\hline
\end{tabular}

Notes. Each cell represents a coefficient estimate using IV regression, where the distance to the capital Cairo and the distance to the capital Cairo interacted with a female dummy are used to instrument the number of "martyrs" by governorate and the interaction term between the number of "martyrs" by governorate and the female dummy. The number of "martyrs" represents the number of fatalities from the $25^{\text {th }}$ of January 2011 to the end of June 2012, by governorate and is expressed in hundreds. A female dummy is included which results from firstdifferencing our equation in level (from the interaction term between female and 2012 in Equation 1). The dependent variable and all control variables are first-differenced. Labor force participation, unemployment and employment are defined according to the current work status. The reference period for the labor market information is 3 months. The labor force includes all those who are engaged in economic activity for purposes of market exchange and excludes subsistence workers, following the market definition of economic activity (see ILO, 1982). Individual controls include the following variables in first-difference: a dummy variable for ever-married status, three dummies for educational attainment: primary and preparatory education, secondary education (either general or vocational) and above secondary education (either postsecondary institute or university education and above). The reference category is no educational degree (either illiterate or literate without any diploma). Household controls include the following variables in first difference: a rural dummy, an indicator for male headed household, household size, the number of adults aged 15 to 64 years old, a dummy variable for land ownership, an indicator for the head's marital status being single and three dummies for the head of the household's educational attainment. Pre-revolution governorate controls include the following variables as well as their interaction terms with a female dummy: the share of public sector employment by governorate in 2006, the number of police stations by governorate per 10,000 inhabitants, the average number of years of schooling for individuals aged 15 -30 by governorate in 2006, the population density by governorate in 2006, the natural log of GDP per capita by governorate in 2005/2006 and a dummy variable for fully urban governorates (Cairo, Alexandria, Suez and Port Said). ${ }^{* * *} \mathrm{p}<0.01,{ }^{* *} \mathrm{p}<0.05$, ${ }^{*} \mathrm{p}<0.1$. Robust standard errors in brackets are clustered at the community level. The reported Kleibergen-Paap rk Wald F-statistic corresponds to the first stage IV regression F-statistic. The Stock-Yogo weak identification test critical values are 7.03, 4.58, 3.95 and 3.63, at the 10\%, 15\%, 20\% and 25\% maximal IV size respectively. The table also reports the p-value of a test with null hypothesis $\alpha_{1}+\alpha_{2}=0$ to check whether the protests significantly affect women's outcomes of interest. 
Online Appendix Table 5: Differential Effect of the Protests on Monthly, Hourly Wages and Hours Worked/Week in Private Versus Public Sector

\begin{tabular}{|c|c|c|c|c|c|c|}
\hline & \multicolumn{2}{|c|}{ Log of monthly wage } & \multicolumn{2}{|c|}{ Log of hourly wage } & \multicolumn{2}{|c|}{ Hours worked/week } \\
\hline & (1) & (2) & (3) & (4) & (5) & (6) \\
\hline VARIABLES & OLS & IV & OLS & IV & OLS & IV \\
\hline \multirow[t]{2}{*}{ Martyrs $\times$ private } & 0.020 & 0.028 & 0.012 & 0.029 & -0.610 & $-4.954 * *$ \\
\hline & {$[0.042]$} & [0.110] & {$[0.038]$} & [0.101] & [0.734] & {$[2.320]$} \\
\hline \multirow[t]{2}{*}{ Martyrs } & -0.014 & -0.083 & -0.007 & -0.101 & -0.520 & -0.816 \\
\hline & {$[0.024]$} & {$[0.067]$} & {$[0.026]$} & {$[0.065]$} & {$[0.436]$} & [1.077] \\
\hline Observations & 3,738 & 3,738 & 3,738 & 3,738 & 3,738 & 3,738 \\
\hline R-squared & 0.030 & 0.025 & 0.037 & 0.030 & 0.020 & 0.005 \\
\hline Individual Controls & YES & YES & YES & YES & YES & YES \\
\hline Household Controls & YES & YES & YES & YES & YES & YES \\
\hline Pre-revolution governorate controls & YES & YES & YES & YES & YES & YES \\
\hline $\mathrm{H}_{0}: \alpha_{1}+\alpha_{2}=0$ (P-value) & 0.855 & 0.566 & 0.875 & 0.417 & 0.051 & 0.005 \\
\hline Kleibergen-Paap rk Wald F statistic & 21.935 & 21.935 & 21.935 & 21.935 & 21.935 & 21.935 \\
\hline
\end{tabular}

are used to instrument the number of "martyrs" by governorate and the interaction term between the number of "martyrs" by governorate and a dummy for private sector employment in 2012 . The number of "martyrs" represents the number of fatalities from the 25th of January 2011 to the end of June 2012, by governorate and is expressed in hundreds. A female dummy is included which results from first-differencing our equation in level (from the interaction term between female and 2012 in Equation 1). The dependent variable and all control variables are first-differenced. Monthly and hourly wages are calculated in constant 2006 Egyptian Pounds and refer to the monthly/hourly wage in primary job, conditional on being employed, in log specification. The hours of work refer to the current number of work hours per week, excluding subsistence work (market definition of economic activity) and conditional on being employed. Individual controls include the following variables in first-difference: a dummy variable for ever-married status, three dummies for educational attainment: primary and preparatory education, secondary education (either general or vocational) and above secondary education (either post-secondary institute or university education and above). The reference category is no educational degree (either illiterate or literate without any diploma). Household controls include the following variables in first difference: a rural dummy, an indicator for male headed household, household size, is no educational degree (either illiterate or literate without any diploma). Household controls include the following variables in first difference: a rural dummy, an indicator for male headed household, household size, the number of adults aged 15 to 64 years old, a dummy variable for land ownership, an indicator for the head's marital status being single and three dummies for the head of the household's educational attainment. Prerevolution governorate controls include the following variables as well as their interaction terms with a dummy for private sector employment in 2012: the share of public sector employment by governorate in 2006, the number of police stations by governorate per 10,000 inhabitants, the average number of years of schooling for individuals aged $15-30$ by governorate in 2006, the population density by governorate in 2006 , the natural log of GDP per capita by governorate in $2005 / 2006$ and a dummy variable for fully urban governorates (Cairo, Alexandria, Suez and Port Said). ${ }^{* * *} \mathrm{p}<0.01, * * \mathrm{p}<0.05, * \mathrm{p}<0.1$. Robust standard errors in brackets are
clustered at the community level. The reported Kleibergen-Paap rk Wald F-statistic corresponds to the first stage IV regression F-statistic. The Stock-Yogo weak identification test critical values are $7.03,4.58,3.95$ and clustered at the community level. The reported Kleibergen-Paap rk Wald F-statistic corresponds to the first stage IV regression F-statistic. The Stock-Yogo weak identification test critical values are $7.03,4.58$, 3.95 and
3.63 , at the $10 \%, 15 \%, 20 \%$ and $25 \%$ maximal IV size respectively. The table also reports the p-value of a test with null hypothesis $\alpha_{1}+\alpha_{2}=0$ to check whether the protests significantly affect outcomes of interest in the private sector. 


\section{Online Appendix Table 6: Association between Female Labor Force Participation and Husband's Wage and Its Variance}

\begin{tabular}{|c|c|c|c|}
\hline \multirow[b]{2}{*}{ VARIABLES } & \multicolumn{3}{|c|}{ Labor Force Participation } \\
\hline & $\begin{array}{c}\text { (1) } \\
\text { OLS }\end{array}$ & $\begin{array}{c}\text { (2) } \\
\text { OLS }\end{array}$ & $\begin{array}{c}(3) \\
\text { OLS }\end{array}$ \\
\hline Husband's monthly wage & $\begin{array}{c}-0.018 * * * \\
{[0.005]}\end{array}$ & & $\begin{array}{c}-0.018 * * * \\
{[0.005]}\end{array}$ \\
\hline Variance of husband's monthly wage & & $\begin{array}{c}-0.001 \\
{[0.009]}\end{array}$ & $\begin{array}{c}-0.006 \\
{[0.009]}\end{array}$ \\
\hline Observations & 3,708 & 3,708 & 3,708 \\
\hline R-squared & 0.034 & 0.029 & 0.034 \\
\hline Individual Controls & YES & YES & YES \\
\hline Household Controls & YES & YES & YES \\
\hline Pre-revolution governorate controls & YES & YES & YES \\
\hline
\end{tabular}

Notes. Each cell represents a coefficient estimate using OLS regression. Our estimation sample only includes working-age married women, living in male-headed households. ${ }^{* * *} \mathrm{p}<0.01,{ }^{* *} \mathrm{p}<0.05,{ }^{*} \mathrm{p}<0.1$. Robust standard errors in brackets are clustered at the community level. The dependent variable and all control variables are first-differenced. Labor force participation, is defined according to the current work status. The reference period for the labor market information is 3 months. The labor force includes all those who are engaged in economic activity for purposes of market exchange and excludes subsistence workers, following the market definition of economic activity (see ILO, 1982). Husband's monthly wage is calculated in constant 2006 Egyptian Pounds and refers to the monthly wage in primary job, conditional on being employed, in log specification and first differenced between 2012 and 2006 . The variance in husband's monthly wage is computed as the change in the logarithm of the variance of the logarithm of wage between 2012 and 2006. We construct this measure by occupation using 4 occupational groups, by occupation and education using 4 occupational groups and 4 educational levels, and by occupation and gender, using the same occupational groups. The occupational groups are defined according to the ISCO-88 occupation classification: low-skilled blue collar, high-skilled blue collar, low-skilled white collar and high-skilled white collar. The educational levels are the following: no education, primary/preparatory education, secondary education and above secondary education. Individual controls include the following variables in first-difference: three dummies for educational attainment: primary and preparatory education, secondary education (either general or vocational) and above secondary education (either post-secondary institute or university education and above). The reference category is no educational degree (either illiterate or literate without any diploma). Household controls include the following variables in first difference: a rural dummy, household size, the number of adults aged 15 to 64 years old, a dummy variable for land ownership and three dummies for the head of the household's educational attainment. Pre-revolution governorate controls include the following variables: the share of public sector employment by governorate in 2006, the number of police stations by governorate per 10,000 inhabitants, the average number of years of schooling for individuals aged 15-30 by governorate in 2006, the population density by governorate in 2006, the natural log of GDP per capita by governorate in 2005/2006 and a dummy variable for fully urban governorates (Cairo, Alexandria, Suez and Port Said).

\section{Online Appendix Table 7: Initial Mean of Hourly Wage}

\begin{tabular}{lccc} 
& Males & Females & Difference \\
\hline No educational degree & 1.295 & 0.181 & $1.114^{* * *}$ \\
Primary/Preparatory education & 1.861 & 1.282 & 0.579 \\
Secondary education & 2.318 & 7.435 & $-5.117^{* * *}$ \\
Above secondary education & 4.087 & 5.738 & $-1.650^{* *}$ \\
\hline
\end{tabular}

Notes. *** $\mathrm{p}<0.01, * * \mathrm{p}<0.05, * \mathrm{p}<0.1$. Hourly wages are reported in Egyptian Pounds from the ELMPS 2006, for the different levels of educational attainment: no educational degree (either illiterate or literate without any diploma), primary and preparatory education, secondary education (either general or vocational) and above secondary education (either post-secondary institute or university education and above). Hourly wages are reported for males and females, as well as the difference between their hourly wages. 
Online Appendix Table 8: Gender Gap in Children's Education

\begin{tabular}{|c|c|c|c|c|c|c|c|c|c|c|c|c|}
\hline \multirow[b]{2}{*}{ VARIABLES } & \multicolumn{4}{|c|}{ Going to school } & \multicolumn{4}{|c|}{$\begin{array}{c}\text { Going to religious school } \\
\text { unconditional on studying }\end{array}$} & \multicolumn{4}{|c|}{$\begin{array}{c}\text { Going to religious school } \\
\text { conditional on studying at present }\end{array}$} \\
\hline & $\begin{array}{c}\text { (1) } \\
\text { OLS }\end{array}$ & $\begin{array}{l}\text { (2) } \\
\text { IV }\end{array}$ & $\begin{array}{c}\text { (3) } \\
\text { OLS }\end{array}$ & $\begin{array}{l}\text { (4) } \\
\text { IV }\end{array}$ & $\begin{array}{l}(5) \\
\text { OLS }\end{array}$ & $\begin{array}{l}\mathbf{( 6 )} \\
\text { IV } \\
\end{array}$ & $\begin{array}{l}\text { (7) } \\
\text { OLS }\end{array}$ & $\begin{array}{l}\text { (8) } \\
\text { IV }\end{array}$ & $\begin{array}{l}\text { (9) } \\
\text { OLS }\end{array}$ & $\begin{array}{l}\text { (10) } \\
\text { IV }\end{array}$ & $\begin{array}{l}(11) \\
\text { OLS } \\
\end{array}$ & $\begin{array}{l}\text { (12) } \\
\text { IV }\end{array}$ \\
\hline Martyrs $\times$ girl & $\begin{array}{c}-0.007 \\
{[0.007]}\end{array}$ & $\begin{array}{c}0.031 \\
{[0.028]}\end{array}$ & $\begin{array}{c}-0.025 \\
{[0.019]}\end{array}$ & $\begin{array}{c}0.048 \\
{[0.058]}\end{array}$ & $\begin{array}{c}-0.003 \\
{[0.003]}\end{array}$ & $\begin{array}{c}-0.017 \\
{[0.019]}\end{array}$ & $\begin{array}{c}-0.002 \\
{[0.012]}\end{array}$ & $\begin{array}{c}-0.032 \\
{[0.042]}\end{array}$ & $\begin{array}{c}-0.004 \\
{[0.004]}\end{array}$ & $\begin{array}{c}-0.025 \\
{[0.019]}\end{array}$ & $\begin{array}{c}-0.002 \\
{[0.0121}\end{array}$ & $\begin{array}{r}-0.044 \\
{[0.046]}\end{array}$ \\
\hline Martyrs & $\begin{array}{l}0.007 \\
{[0.006]}\end{array}$ & $\begin{array}{l}-0.026 \\
{[0.019]}\end{array}$ & $\begin{array}{l}0.030^{*} \\
{[0.016]}\end{array}$ & $\begin{array}{l}-0.034 \\
{[0.044]}\end{array}$ & $\begin{array}{l}-0.003 \\
{[0.002]}\end{array}$ & $\begin{array}{c}0.007 \\
{[0.013]}\end{array}$ & $\begin{array}{c}0.003 \\
{[0.009]}\end{array}$ & $\begin{array}{c}0.021 \\
{[0.030]}\end{array}$ & $\begin{array}{l}-0.003 \\
{[0.002]}\end{array}$ & $\begin{array}{c}0.007 \\
{[0.013]}\end{array}$ & $\begin{array}{c}0.003 \\
{[0.009]}\end{array}$ & $\begin{array}{c}0.022 \\
{[0.031]}\end{array}$ \\
\hline Observations & 1,856 & 1,856 & 1,856 & 1,856 & 1,760 & 1,760 & 1,760 & 1,760 & 1,647 & 1,647 & 1,647 & 1,647 \\
\hline R-squared & 0.009 & 0.005 & 0.021 & 0.007 & 0.006 & 0.004 & 0.012 & 0.009 & 0.008 & 0.002 & 0.014 & 0.009 \\
\hline Individual Controls & YES & YES & YES & YES & YES & YES & YES & YES & YES & YES & YES & YES \\
\hline Household Controls & YES & YES & YES & YES & YES & YES & YES & YES & YES & YES & YES & YES \\
\hline Pre-revolution governorate controls & & & YES & YES & & & YES & YES & & & YES & YES \\
\hline $\begin{array}{l}\mathrm{H}_{0}: \alpha_{1}+\alpha_{2}=0 \text { (P-value) } \\
\text { (Pleiproen-Pazn rk }\end{array}$ & 0.954 & $\begin{array}{c}0.783 \\
12363\end{array}$ & 0.698 & $\begin{array}{r}0.775 \\
28567\end{array}$ & 0.018 & 0.493 & 0.854 & 0.716 & 0.007 & 0.220 & 0.926 & $\begin{array}{r}0.502 \\
26735\end{array}$ \\
\hline
\end{tabular}
number of "martyrs" by governorate and the interaction term between the number of "martyrs" by governorate and the female dummy. The number of "martyrs" represents the number of fatalities from the $25^{\text {th }}$ of January 2011 to the end of June 2012, by governorate and is expressed in hundreds. Our estimation sample is children aged between 6 and 15 years old in the two waves of the panel 2006 and 2012 . A dummy variable for being a girl is included which results from first-differencing our equation in level (from the interaction term between female and 2012 in Equation 1). The dependent variable and all control variables are first-differenced. The dependent variable in columns (1) to (4) is the first difference between dummy variable indicators for going to school at present in the two waves. Dependent variable in columns (5) to (8) is the first difference between dummy variable indicators for going to religious school (Azhari) at present in the two waves, unconditional on studying. The dependent variable in columns (9) to (12) is the first difference between dummy variable indicators for going to religious school (Azhari) at present in the two waves, conditional on studying. Household controls include the following variables in first difference: a rural dummy, an indicator for male headed household, household size, the number of adults aged 15 to 64 years old, a dummy variable for land ownership, an indicator for the head's marital status being single and three dummies for the head of the household's educational attainment. Pre-revolution governorate controls include the following variables as well as their interaction terms with a female dummy: the share of public sector employment by governorate in 2006, the number of police stations by governorate per 10,000 inhabitants, the average number of years of schooling for individuals aged 15-30 by governorate in 2006, the population density by governorate in 2006, the natural log of GDP per capita by governorate in 2005/2006 and a dummy variable for fully urban governorates (Cairo, Alexandria, Suez and Port Said) *** p<0.01 ** p<0.05, * p $<0.1$. Robust standard errors in brackets are clustered at the 3.63 , at the $10 \%, 15 \%, 20 \%$ and $25 \%$ maximal IV size respectively. The table also reports the p-value of a test with null hypothesis $\alpha_{1}+\alpha_{2}=0$ to check whether the protests significantly affect girls' outcomes of interest. 


\section{Online Appendix Table 9: Number of “Martyrs” by Governorate}

\begin{tabular}{lcc} 
Governorates & Martyrs 25 Jan 2011 - 11 Feb 2011 & Martyrs 12 Feb 2011 - 30 June 2012 \\
\hline Cairo & 406 & 174 \\
Alexandria & 132 & 5 \\
Port Said & 14 & 74 \\
Suez & 33 & 13 \\
Damietta & 3 & 2 \\
Dakahlia & 11 & 4 \\
Sharkia & 9 & 9 \\
Kalyoubia & 63 & 6 \\
Kafr-Elsheikh & 6 & 0 \\
Gharbia & 20 & 9 \\
Menoufia & 20 & 4 \\
Behera & 36 & 10 \\
Ismailia & 19 & 9 \\
Giza & 90 & 29 \\
Beni-Suef & 22 & 0 \\
Fayoum & 55 & 4 \\
Menia & 0 & 14 \\
Asyout & 3 & 7 \\
Suhag & 1 & 3 \\
Qena & 9 & 2 \\
Aswan & 3 & 2 \\
Luxur & 9 & \\
\hline Notes. Dataura & \\
\hline
\end{tabular}

Notes. Data source is the Statistical Database of the Egyptian Revolution. The number of "martyrs" represents the number of fatalities, by governorate. It is reported for the first 18 days of the Egyptian revolution from the $25^{\text {th }}$ of January 2011 till the $11^{\text {th }}$ of February 2011 , when Mubarak stepped down, and from the $12^{\text {th }}$ of February 2011 till the end of June 2012, when the Supreme Council of the Armed Forces (SCAF) took power in Egypt in the name of the military.

\section{Online Appendix Table 10: OLS estimations of Equation (1)}

\begin{tabular}{|c|c|c|c|}
\hline & Labor Force Participation & Unemployment & Employment \\
\hline VARIABLES & \begin{tabular}{|c|c|} 
(1) \\
OLS \\
\end{tabular} & $\begin{array}{l}\text { (2) } \\
\text { OLS }\end{array}$ & $\begin{array}{c}\text { (3) } \\
\text { OLS }\end{array}$ \\
\hline Martyrs $\times$ year $\times$ female & $\begin{array}{c}0.020 * * * \\
{[0.005]}\end{array}$ & $\begin{array}{c}0.001 \\
{[0.003]}\end{array}$ & $\begin{array}{c}0.019 * * * \\
{[0.005]}\end{array}$ \\
\hline Martyrs $\times$ year & $\begin{array}{c}-0.011^{* * *} \\
{[0.003]}\end{array}$ & $\begin{array}{c}-0.003 \\
{[0.003]}\end{array}$ & $\begin{array}{c}-0.008 * * \\
{[0.004]}\end{array}$ \\
\hline Martyrs $\times$ female & $\begin{array}{c}-0.106 * * * \\
{[0.031]}\end{array}$ & $\begin{array}{c}-0.014 \\
{[0.012]}\end{array}$ & $\begin{array}{c}-0.092 * * * \\
{[0.035]}\end{array}$ \\
\hline Year $\times$ female & $\begin{array}{c}-0.090 * * * \\
{[0.010]}\end{array}$ & $\begin{array}{c}0.007 \\
{[0.006]}\end{array}$ & $\begin{array}{c}-0.097 * * * \\
{[0.010]}\end{array}$ \\
\hline Observations & 28,070 & 28,070 & 28,070 \\
\hline R-squared & 0.808 & 0.577 & 0.815 \\
\hline Individual Controls & YES & YES & YES \\
\hline Household Controls & YES & YES & YES \\
\hline Individual FE & YES & YES & YES \\
\hline Governorate FE & YES & YES & YES \\
\hline Year FE & YES & YES & YES \\
\hline
\end{tabular}

Notes. Each cell represents a coefficient estimate using OLS regressions. The number of "martyrs" represents the number of fatalities from the 25th of January 2011 to the end of June 2012, by governorate and is expressed in hundreds. ${ }^{* * *} \mathrm{p}<0.01, * * \mathrm{p}<0.05, * \mathrm{p}<0.1$. Robust standard errors in brackets are clustered at the community level. The dependent variable is a dummy variable for the following labor market outcomes. Labor force participation, unemployment and employment are defined according to the current work status. The reference period for the labor market information is 3 months. The labor force includes all those who are engaged in economic activity for purposes of market exchange and excludes subsistence workers, following the market definition of economic activity (see ILO, 1982). Individual controls include the following variables: a dummy variable for ever-married status, three dummies for educational attainment: primary and preparatory education, secondary education (either general or vocational) and above secondary education (either post-secondary institute or university education and above). The reference category is no educational degree (either illiterate or literate without any diploma). Household controls include the following variables: a rural dummy, an indicator for male headed household, household size, the number of adults aged 15 to 64 years old, a dummy variable for land ownership, an indicator for the head's marital status being single and three dummies for the head of the household's educational attainment. Regressions include individual fixed effects, governorate fixed effects and a year fixed effect for 2012. 
Online Appendix Table 11: IV Ordered Probit Estimations

\begin{tabular}{|c|c|c|c|c|c|c|c|c|c|}
\hline & \multicolumn{3}{|c|}{ Labor Force participation } & \multicolumn{3}{|c|}{ Unemployment } & \multicolumn{3}{|c|}{ Employment } \\
\hline & $(-1)$ & (0) & (1) & $(-1)$ & (0) & (1) & $(-1)$ & (0) & (1) \\
\hline \multirow{2}{*}{ Martyrs $\times$ female } & $-0.065^{* * *}$ & $-0.011^{* * *}$ & $0.076^{* * *}$ & $-0.029 * * *$ & -0.002 & $0.031^{* * *}$ & $-0.039 * * *$ & $-0.008^{* * *}$ & $0.047^{* * *}$ \\
\hline & [0.012] & {$[0.003]$} & [0.014] & {$[0.008]$} & [0.002] & {$[0.008]$} & {$[0.012]$} & [0.003] & [0.014] \\
\hline \multirow[t]{2}{*}{ Martyrs } & $0.013^{*}$ & $0.002 *$ & $-0.016^{*}$ & 0.006 & 0.000 & -0.007 & 0.007 & 0.001 & -0.008 \\
\hline & {$[0.007]$} & {$[0.001]$} & {$[0.008]$} & {$[0.005]$} & {$[0.000]$} & {$[0.005]$} & {$[0.008]$} & {$[0.003]$} & [0.009] \\
\hline Observations & 14,035 & 14,035 & 14,035 & 14,035 & 14,035 & 14,035 & 14,035 & 14,035 & 14,035 \\
\hline Pseudo R-squared & 0.105 & 0.105 & 0.105 & 0.061 & 0.061 & 0.061 & 0.075 & 0.075 & 0.075 \\
\hline Individual Controls & YES & YES & YES & YES & YES & YES & YES & YES & YES \\
\hline Household Controls & YES & YES & YES & YES & YES & YES & YES & YES & YES \\
\hline Pre-revolution Governorate Controls & YES & YES & YES & YES & YES & YES & YES & YES & YES \\
\hline
\end{tabular}

Notes. Each cell represents marginal effects using IV ordered probit, fitting an observed recursive mixed process model, with the governorate level number of "martyrs" and its interaction term with the female dummy considered as endogenous regressors instrumented by the distance to the capital Cairo and the distance to the capital Cairo interacted with a female dummy. The number of "martyrs" represents the number of fatalities from the $25^{\text {th }}$ of January 2011 to the end of June 2012, by governorate and is expressed in hundreds. *** $p<0.01, * * \mathrm{p}<0.05$, * $\mathrm{p}<0.1$. Robust standard errors are reported in brackets. A female dummy is included which results from first-differencing our equation in level (from the interaction term between female and 2012 in Equation 1). The dependent variable and all control variables are first-differenced. The dependent variable is a categorical variable taking values $-1,0,1$. The category (-1) indicates individuals who participated in the Egyptian labor market in 2006 and not in 2012 . The category (0) indicates individuals who either participated in categorical variable taking values -1, 0 , 1. The category (-1) indicates individuals who participated in the Egyptian labor market in 2006 and not in 2012 . The category (0) indicates individuals who either participated in the labor market in the two years or individuals who never participated. The category (1) indicates individuals who participated in the labor market in 2012 and not in 2006 . Labor force participation, unemployment and employment are defined according to the current work status. The reference period for the labor market information is 3 months. The labor force includes all those who are engaged in economic activity for purposes of
market exchange and excludes subsistence workers, following the market definition of economic activity (see ILO, 1982). Individual controls include the following variables in first-difference: a dummy variable for ever-married status, three dummies for educational attainment: primary and preparatory education, secondary education (either general or vocational) and above secondary education (either post-secondary institute or university education and above). The reference category is no educational degree (either illiterate or literate without any diploma). Household controls include the following variables in first difference: a rural dummy, an indicator for male headed household, household size, the number of adults aged 15 to 64 years old, a dummy variable for land ownership, an indicator for the head's marital status being single and three dummies for the head of the household's educational attainment. Pre-revolution governorate controls include the following variables as well as their interaction terms with a female dummy: the share of public sector employment by governorate in 2006, the number of police stations by governorate per 10,000 inhabitants, the average number of years of schooling for individuals aged 15-30 by governorate in 2006, the population density by governorate in 2006, the natural log of GDP per capita by governorate in 2005/2006 and a dummy variable for fully urban governorates (Cairo, Alexandria, Suez and Port Said). 
Online Appendix Table 12: Labor Force Participation, Unemployment and Employment (Sample of Couples)

\begin{tabular}{|c|c|c|c|c|c|c|c|c|c|c|c|c|}
\hline \multirow[b]{3}{*}{ VARIABLES } & \multicolumn{4}{|c|}{ Labor Force Participation } & \multicolumn{4}{|c|}{ Unemployment } & \multicolumn{4}{|c|}{ Employment } \\
\hline & (1) & (2) & (3) & (4) & (5) & (6) & (7) & (8) & (9) & (10) & (11) & (12) \\
\hline & OLS & IV & OLS & IV & OLS & IV & OLS & IV & OLS & IV & OLS & IV \\
\hline Martyrs $\times$ female & $0.017^{* * *}$ & $0.086^{* * *}$ & 0.004 & $0.092 * *$ & 0.000 & $0.017^{* * *}$ & 0.004 & $0.035 * * *$ & $0.017^{* * *}$ & $0.068^{* * *}$ & -0.000 & 0.057 \\
\hline & $\begin{array}{c}{[0.005]} \\
-0.005 * * *\end{array}$ & $\begin{array}{c}{[0.023]} \\
-0.005\end{array}$ & $\begin{array}{c}{[0.011]} \\
0.004\end{array}$ & $\begin{array}{l}{[0.037]} \\
-0.003\end{array}$ & $\begin{array}{c}{[0.003]} \\
-0.000\end{array}$ & $\begin{array}{c}{[0.006]} \\
0.000\end{array}$ & $\begin{array}{c}{[0.006]} \\
0.002\end{array}$ & $\begin{array}{c}{[0.013]} \\
-0.001\end{array}$ & $\begin{array}{c}{[0.005]} \\
-0.005 * * *\end{array}$ & $\begin{array}{c}{[0.022]} \\
-0.005\end{array}$ & $\begin{array}{c}{[0.010]} \\
0.002\end{array}$ & $\begin{array}{l}{[0.036]} \\
-0.002\end{array}$ \\
\hline Martyrs & $\begin{array}{c}-0.005^{* * *} \\
{[0.002]}\end{array}$ & $\begin{array}{c}-0.005 \\
{[0.004]}\end{array}$ & $\begin{array}{c}0.004 \\
{[0.004]}\end{array}$ & {$[0.009]$} & {$[0.002]$} & {$[0.002]$} & {$[0.003]$} & {$[0.007]$} & {$[0.001]$} & $\begin{array}{l}-0.005 \\
{[0.003]}\end{array}$ & $\begin{array}{c}0.002 \\
{[0.003]}\end{array}$ & $\begin{array}{l}-0.002 \\
{[0.008]}\end{array}$ \\
\hline Observations & 7,416 & 7,416 & 7,416 & 7,416 & 7,416 & 7,416 & 7,416 & 7,416 & 7,416 & 7,416 & 7,416 & 7,416 \\
\hline R-squared & 0.121 & 0.073 & 0.136 & 0.12 & 0.015 & 0.004 & 0.023 & 0.017 & 0.187 & 0.157 & 0.201 & 0.193 \\
\hline Individual Controls & YES & YES & YES & YES & YES & YES & YES & YES & YES & YES & YES & YES \\
\hline Household Controls & YES & YES & YES & YES & YES & YES & YES & YES & YES & YES & YES & YES \\
\hline Pre-revolution governorate controls & & & YES & YES & & & YES & YES & & & YES & YES \\
\hline $\mathrm{H}_{0}: \alpha_{1}+\alpha_{2}=0$ (P-value $)$ & 0.008 & 0.000 & 0.433 & 0.008 & 0.995 & 0.000 & 0.205 & 0.002 & 0.006 & 0.002 & 0.843 & 0.092 \\
\hline Kleibergen-Paap rk Wald F statistic & & 25.850 & & 64.384 & & 25.850 & & 64.384 & & 25.850 & & 64.850 \\
\hline
\end{tabular}

Notes. Each cell represents a coefficient estimate using OLS or IV regressions, where the distance to the capital Cairo and the distance to the capital Cairo interacted with a female dummy are used to instrument the number of "martyrs" by governorate and the interaction term between the number of "martyrs" by governorate and the female dummy. The number of "martyrs" represents the number of fatalities from the $25^{\text {th }}$ of January 2011 to the end of June 2012, by governorate and is expressed in hundreds. Our estimation sample only includes couples. Both the head of the household and his/her spouse are in the working age category (15-64 years old) and are married in the two years of the survey, 2006 and 2012. A female dummy is included which results from first-differencing our equation in level (from the interaction term between female and 2012 in Equation 1). The dependent variable and all control variables are first-differenced. Labor force participation, unemployment and employment are defined according to the current work status. The reference period for the labor market information is 3 months. The labor force includes all those who are engaged in economic activity for purposes of market exchange and excludes subsistence workers, following the market definition of economic activity (see ILO, 1982). Individual controls include the following variables in first-difference: three dummies for educational attainment: primary and preparatory education, secondary education (either general or vocational) and above secondary education (either post-secondary institute or university education and above). The reference category is no educational degree (either illiterate or literate without any diploma). Household controls include the following variables in first difference: a rural dummy, household size, the number of adults aged 15 to 64 years old, a dummy variable for land ownership and three dummies for the head of the household's educational attainment. Pre-revolution governorate controls include the following variables as well as their interaction terms with a female dummy: the share of public sector employment by governorate in 2006, the number of police stations by governorate per 10,000 inhabitants, the average number of years of schooling for individuals aged 15-30 by governorate in 2006, the population density by governorate in 2006, the 2006, the number of police stations by governorate per 10,000 inhabitants, the average number of years of schooling for individuals aged 15-30 by governorate in 2006, the population density by governorate in 2006 , the natural log of GDP per capita by governorate in $2005 / 2006$ and a dummy variable for fully urban governorates (Cairo, Alexandria, Suez and Port Said). ${ }^{* * *} \mathrm{p}<0.01, * * \mathrm{p}<0.05,{ }^{*} \mathrm{p}<0.1$. Robust standard errors in brackets
are clustered at the community level. The reported Kleibergen-Paap rk Wald F-statistic corresponds to the first stage IV regression F-statistic. The Stock-Yogo weak identification test critical values are $7.03,4.58,3.95$ are clustered at the community level. The reported Kleibergen-Paap rk Wald F-statistic corresponds to the first stage IV regression F-statistic. The Stock-Yogo weak identification test critical values are $7.03,4.58,3.95$ interest. 
Online Appendix Table 13: Decision Making

\begin{tabular}{|c|c|c|c|c|c|c|c|c|c|c|}
\hline & Decision 1 & Decision 2 & Decision 3 & Decision 4 & Decision 5 & Decision 6 & Decision 7 & Decision 8 & Decision 9 & Decision 10 \\
\hline & (1) & (2) & (3) & (4) & (5) & (6) & (7) & (8) & (9) & (10) \\
\hline VARIABLES & IV & IV & IV & IV & IV & IV & IV & IV & IV & IV \\
\hline Martyrs $\times$ female & $\begin{array}{c}0.058 \\
{[0.056]}\end{array}$ & $\begin{array}{c}-0.130 * * \\
{[0.056]}\end{array}$ & $\begin{array}{c}-0.199 * * * \\
{[0.051]}\end{array}$ & $\begin{array}{c}0.023 \\
{[0.056]}\end{array}$ & $\begin{array}{c}-0.189 * * * \\
{[0.047]}\end{array}$ & $\begin{array}{c}-0.058 \\
{[0.065]}\end{array}$ & $\begin{array}{c}-0.183^{* * *} \\
{[0.047]}\end{array}$ & $\begin{array}{c}0.095 \\
{[0.059]}\end{array}$ & $\begin{array}{l}-0.115^{*} \\
{[0.061]}\end{array}$ & $\begin{array}{c}0.048 \\
{[0.059]}\end{array}$ \\
\hline Martyrs & $\begin{array}{c}0.019 \\
{[0.027]}\end{array}$ & $\begin{array}{c}0.109 * * * \\
{[0.033]}\end{array}$ & $\begin{array}{c}0.028 \\
{[0.030]}\end{array}$ & $\begin{array}{l}-0.020 \\
{[0.039]}\end{array}$ & $\begin{array}{c}0.089 * * * \\
{[0.034]}\end{array}$ & $\begin{array}{c}0.052 \\
{[0.046]}\end{array}$ & $\begin{array}{c}0.157 * * * \\
{[0.042]}\end{array}$ & $\begin{array}{c}-0.032 \\
{[0.036]}\end{array}$ & $\begin{array}{c}0.138 * * * \\
{[0.036]}\end{array}$ & $\begin{array}{c}0.026 \\
{[0.044]}\end{array}$ \\
\hline Observations & 7,416 & 7,416 & 7,416 & 7,416 & 7,416 & 7,416 & 7,416 & 7,416 & 7,416 & 7,416 \\
\hline R-squared & 0.064 & 0.054 & 0.033 & 0.054 & 0.025 & 0.032 & 0.022 & 0.082 & 0.043 & 0.049 \\
\hline Individual Controls & YES & YES & YES & YES & YES & YES & YES & YES & YES & YES \\
\hline Household Controls & YES & YES & YES & YES & YES & YES & YES & YES & YES & YES \\
\hline Pre-revolution governorate controls & YES & YES & YES & YES & YES & YES & YES & YES & YES & YES \\
\hline $\mathrm{H}_{0}: \alpha_{1}+\alpha_{2}=0$ (P-value) & 0.088 & 0.568 & 0.000 & 0.908 & 0.006 & 0.864 & 0.422 & 0.104 & 0.572 & 0.073 \\
\hline Kleibergen-Paap rk Wald F statistic & 53.139 & 53.139 & 53.139 & 53.139 & 53.139 & 53.139 & 53.139 & 53.139 & 53.139 & 53.139 \\
\hline
\end{tabular}

Notes. Each cell represents a coefficient estimate using IV regression, where the distance to the capital Cairo and the distance to the capital Cairo interacted with a female dummy are used to instrument the number of "martyrs" by governorate and the interaction term between the number of "martyrs" by governorate and the female dummy. The number of "martyrs" represents the number of fatalities from the $25^{\text {th }}$ of January 2011 to the end of June 2012, by governorate and is expressed in hundreds. Our estimation sample only includes couples. Both the head of the household and his/her spouse are in the working age category (15-64 years old) and are married in the two years of the survey, 2006 and 2012. A female dummy is included which results from first-differencing our equation in level (from the interaction term between female and 2012 in Equation 1 ). The
dependent variable and all control variables are first-differenced. The dependent variables are a set of decision-making questions concerning who in the family has the final say regarding these decisions. Decision 1 dependent variable and all control variables are first-differenced. The dependent variables are a set of decision-making questions concerning who in the family has the final say regarding these decisions. Decision 1
corresponds to making large household purchases. Decision 2 corresponds to making household purchases for daily needs. Decision 3 corresponds to visits to family, friends and relatives. Decision 4 corresponds to what food should be cooked each day. Decision 5 corresponds to "getting medical treatment or advice for yourself". Decision 6 corresponds to "buying clothes for yourself". Decision 7 corresponds to taking child to the doctor. Decision 8 corresponds to dealing with children's school and teachers. Decision 9 corresponds to sending child to school on a daily basis. Decision 10 corresponds to buying clothes or other needs for children. Individual controls include the following variables in first-difference: three dummies for educational attainment: primary and preparatory education, secondary education (either general or vocational) and above secondary education (either post-secondary institute or university education and above). The reference category is no educational degree (either illiterate or literate without any diploma). Household controls include the following variables in first difference: a rural dummy, household size, the number of adults aged 15 to 64 years old, a dummy variable for land ownership and three dummies for the head of the household's educational attainment. Pre-revolution governorate controls include the following variables as well as their interaction terms with a female dummy: the share of public sector employment by governorate in 2006, the number of police stations by governorate per 10,000 inhabitants, the average number of years of schooling for individuals aged 15-30 by governorate in 2006, the population density by governorate in 2006, the natural log of GDP per capita by governorate in 2005/2006 and a dummy variable for fully urban governorates (Cairo, Alexandria, Suez and Port Said). *** p $<0.01$, ** p $<0.05$, * p $<0.1$. Robust standard errors in brackets are clustered at the community governorate in $2005 / 2006$ and a dummy variable for fulty urban governorates (Cairo, Alexandria, Suez and Port Said). $* * * \mathrm{p}<0.01, * \mathrm{p}<0.05$, $\mathrm{p}^{2}<0.1$. Robust standard errors in brackets are clustered at the community and $25 \%$ maximal IV size respectively. The table also reports the p-value of a test with null hypothesis $\alpha_{1}+\alpha_{2}=0$ to check whether the protests significantly affect women's outcomes of interest. 
Online Appendix Table 14: Additional Robustness Checks

\begin{tabular}{|c|c|c|c|c|c|c|}
\hline \multicolumn{7}{|c|}{ Panel A: Using the number of male martyrs by governorate } \\
\hline & \multicolumn{2}{|c|}{ Labor Force Participation } & \multicolumn{2}{|c|}{ Unemployment } & \multicolumn{2}{|c|}{ Employment } \\
\hline & (1) & (2) & (3) & (4) & (5) & (6) \\
\hline VARIABLES & OLS & IV & OLS & IV & OLS & IV \\
\hline \multirow[t]{2}{*}{ Male martyrs $\times$ female } & 0.005 & $0.141 * * *$ & 0.009 & $0.054 * * *$ & -0.004 & $0.087 * *$ \\
\hline & [0.011] & [0.037] & [0.007] & {$[0.016]$} & [0.009] & {$[0.036]$} \\
\hline \multirow[t]{2}{*}{ Male martyrs } & -0.000 & $-0.029 * *$ & -0.006 & -0.014 & 0.006 & -0.015 \\
\hline & {$[0.005]$} & {$[0.014]$} & {$[0.005]$} & {$[0.011]$} & {$[0.006]$} & {$[0.018]$} \\
\hline Observations & 14,035 & 14,035 & 14,035 & 14,035 & 14,035 & 14,035 \\
\hline R-squared & 0.142 & 0.123 & 0.045 & 0.039 & 0.097 & 0.088 \\
\hline Individual Controls & YES & YES & YES & YES & YES & YES \\
\hline Household Controls & YES & YES & YES & YES & YES & YES \\
\hline Pre-revolution Governorate Controls & YES & YES & YES & YES & YES & YES \\
\hline $\mathrm{H}_{0}: \alpha_{1}+\alpha_{2}=0$ (P-value $)$ & 0.591 & 0.001 & 0.608 & 0.003 & 0.774 & 0.018 \\
\hline Kleibergen-Paap rk Wald F statistic & & 39.644 & & 39.644 & & 39.644 \\
\hline \multicolumn{7}{|c|}{ Panel B: Using the number of female martyrs by governorate } \\
\hline & \multicolumn{2}{|c|}{ Labor Force Participation } & \multicolumn{2}{|c|}{ Unemployment } & \multicolumn{2}{|c|}{ Employment } \\
\hline & (1) & (2) & (3) & (4) & (5) & (6) \\
\hline VARIABLES & OLS & IV & OLS & IV & OLS & IV \\
\hline \multirow[t]{2}{*}{ Female martyrs $\times$ female } & 0.001 & $0.066 * * *$ & 0.004 & $0.025^{* * *}$ & -0.003 & $0.041^{* *}$ \\
\hline & [0.005] & [0.018] & {$[0.003]$} & [0.008] & {$[0.004]$} & [0.017] \\
\hline \multirow[t]{2}{*}{ Female martyrs } & -0.001 & $-0.013^{* *}$ & -0.002 & -0.006 & 0.002 & -0.007 \\
\hline & {$[0.002]$} & {$[0.006]$} & {$[0.002]$} & {$[0.005]$} & {$[0.003]$} & {$[0.008]$} \\
\hline Observations & 14,035 & 14,035 & 14,035 & 14,035 & 14,035 & 14,035 \\
\hline R-squared & 0.142 & 0.117 & 0.045 & 0.037 & 0.097 & 0.085 \\
\hline Individual Controls & YES & YES & YES & YES & YES & YES \\
\hline Household Controls & YES & YES & YES & YES & YES & YES \\
\hline Pre-revolution Governorate Controls & YES & YES & YES & YES & YES & YES \\
\hline $\mathrm{H}_{0}: \alpha_{1}+\alpha_{2}=0$ (P-value) & 0.989 & 0.001 & 0.618 & 0.004 & 0.708 & 0.021 \\
\hline Kleibergen-Paap rk Wald F statistic & & 26.836 & & 27.836 & & 28.836 \\
\hline
\end{tabular}

Notes. Each cell represents a coefficient estimate using OLS or IV regressions, where the distance to the capital Cairo and the distance to the capital Cairo interacted with a female dummy are used to instrument the number of "martyrs" by governorate and the interaction term between the number of "martyrs" by governorate and the female dummy. In Panel A, we use the number of male "martyrs" by governorate from 25th of January 2011 till the end of June 2012, expressed in hundreds. In Panel B we use the number of female "martyrs” by governorate from 25th of January 2011 till the end of June 2012, expressed in units. A female dummy is included which results from first-differencing our equation in level (from the interaction term between female and 2012 in Equation 1). The dependent variable and all control variables are firstdifferenced. Labor force participation, unemployment and employment are defined according to the current work status. The reference period for the labor market information is 3 months. The labor force includes all those who are engaged in economic activity for purposes of market exchange and excludes subsistence workers, following the market definition of economic activity (see ILO, 1982). Individual controls include the following variables in first-difference: a dummy variable for ever-married status, three dummies for educational attainment: primary and preparatory education, secondary education (either general or vocational) and above secondary education (either post-secondary institute or university education and above). The reference category is no educational degree (either illiterate or literate without any diploma). Household controls include the following variables in first difference: a rural dummy, an indicator for male headed household, household size, the number of adults aged 15 to 64 years old, a dummy variable for land ownership, an indicator for the head's marital status being single and three dummies for the head of the household's educational attainment. Pre-revolution governorate controls include the following variables as well as their interaction terms with a female dummy: the share of public sector employment by governorate in 2006, the number of police stations by governorate per 10,000 inhabitants, the average number of years of schooling for individuals aged 15-30 by governorate in 2006, the population density by governorate in 2006, the natural log of GDP per capita by governorate in 2005/2006 and a dummy variable for fully urban governorates (Cairo, Alexandria, Suez and Port Said). $* * * \mathrm{p}<0.01, * * \mathrm{p}<0.05, * \mathrm{p}<0.1$. Robust standard errors in brackets are clustered at the community level. The reported Kleibergen-Paap rk Wald F-statistic corresponds to the first stage IV regression F-statistic. The StockYogo weak identification test critical values are 7.03, 4.58, 3.95 and 3.63, at the $10 \%, 15 \%, 20 \%$ and $25 \%$ maximal IV size respectively. The table also reports the $\mathrm{p}$-value of a test with null hypothesis $\alpha 1+\alpha 2=0$ to check whether the protests significantly affect women's outcomes of interest. 
Online Appendix Table 15: Robustness Checks Using the Normalized Number of “Martyrs” by Population Size

\begin{tabular}{|c|c|c|c|c|c|c|c|c|c|c|c|c|}
\hline \multirow[b]{3}{*}{ VARIABLES } & \multicolumn{4}{|c|}{ Labor Force Participation } & \multicolumn{4}{|c|}{ Unemployment } & \multicolumn{4}{|c|}{ Employment } \\
\hline & (1) & (2) & (3) & (4) & (5) & (6) & (7) & (8) & (9) & (10) & (11) & (12) \\
\hline & OLS & IV & OLS & IV & OLS & IV & OLS & IV & OLS & IV & OLS & IV \\
\hline Martyrs per 100,000 inhabitants $\times$ female & $0.014 * * *$ & $0.083^{* * *}$ & 0.001 & $0.077^{* * *}$ & -0.001 & $0.015^{* * *}$ & -0.004 & $0.029 * * *$ & $0.015^{* * *}$ & $0.068^{* * *}$ & 0.006 & $0.047^{* *}$ \\
\hline Martyrs per 100,000 inhabitants & $\begin{array}{c}-0.008 * * * \\
{[0.001]}\end{array}$ & $\begin{array}{c}-0.014^{* * *} \\
{[0.005]}\end{array}$ & $\begin{array}{c}0.002 \\
{[0.005]}\end{array}$ & $\begin{array}{c}-0.015^{* *} \\
{[0.007]}\end{array}$ & $\begin{array}{l}-0.003^{*} \\
{[0.002]}\end{array}$ & $\begin{array}{c}{[-0.004]} \\
{[0.004]}\end{array}$ & $\begin{array}{c}-0.002] \\
{[0.003]}\end{array}$ & $\begin{array}{c}-0.007 \\
{[0.006]}\end{array}$ & $\begin{array}{c}{\left[0.006^{* *}\right.} \\
{[0.002]}\end{array}$ & $\begin{array}{l}-0.010^{*} \\
{[0.006]}\end{array}$ & $\begin{array}{c}{[.010]} \\
0.004 \\
{[0.006]}\end{array}$ & $\begin{array}{c}-0.008 \\
{[0.009]}\end{array}$ \\
\hline Observations & 14,035 & 14,035 & 14,035 & 14,035 & 14,035 & 14,035 & 14,035 & 14,035 & 14,035 & 14,035 & 14,035 & 14,035 \\
\hline R-squared & 0.132 & 0.068 & 0.142 & 0.134 & 0.044 & 0.033 & 0.045 & 0.040 & 0.088 & 0.049 & 0.097 & 0.095 \\
\hline Individual Controls & YES & YES & YES & YES & YES & YES & YES & YES & YES & YES & YES & YES \\
\hline Household Controls & YES & YES & YES & YES & YES & YES & YES & YES & YES & YES & YES & YES \\
\hline Pre-revolution governorate controls & & & YES & YES & & & YES & YES & & & YES & YES \\
\hline $\begin{array}{l}\mathrm{H}_{0}: \alpha_{1}+\alpha_{2}=0 \text { (P-value) } \\
\text { Kleibergen-Paap rk Wald F statistic }\end{array}$ & 0.076 & $\begin{array}{c}0.000 \\
26.029\end{array}$ & 0.714 & $\begin{array}{c}0.000 \\
78.436\end{array}$ & 0.027 & $\begin{array}{c}0.009 \\
26.029\end{array}$ & 0.251 & $\begin{array}{c}0.004 \\
78.436\end{array}$ & 0.000 & $\begin{array}{c}0.000 \\
26.029\end{array}$ & 0.165 & $\begin{array}{c}0.014 \\
78.436\end{array}$ \\
\hline
\end{tabular}

Notes. Each cell represents a coefficient estimate using OLS or IV regressions, where the distance to the capital Cairo and the distance to the capital Cairo interacted with a female dummy are used to instrument the number of "martyrs" per 100,000 inhabitants by governorate and the interaction term between the number of "martyrs" per 100,000 inhabitants by governorate and the female dummy. The number of "martyrs" per 100,000 inhabitants represents the number of fatalities from the $25^{\text {th }}$ of January 2011 to the end of June 2012, normalized by population size in each governorate. A female dummy is included which results from first-differencing our equation in level (from the interaction term between female and 2012 in equation 1). The dependent variable and all control variables are first-differenced. Labor force participation, unemployment and employment are defined according to the current work status. The reference period for the labor market information is 3 months. The labor force includes all those who are engaged in economic activity for purposes of market exchange and excludes subsistence workers, following the market definition of economic activity (see ILO, 1982). Individual controls include the following variables in first-difference: a dummy variable for ever-married status, three dummies for educational attainment: primary and preparatory education, secondary education (either general or vocational) and above secondary education (either post-secondary institute or university education and above). The reference category is no educational degree (either illiterate or literate without any diploma). Household controls include the following variables in first difference: a rural dummy, an indicator for male headed household, household size, the number of adults aged 15 to 64 years old, a dummy variable for land ownership, an indicator for the head's marital status being single and three dummies for the head of the household's educational attainment. Pre-revolution governorate controls include the following variables as well as their interaction terms with a female dummy: the share of public sector employment by governorate in 2006, the number of police stations by governorate per 10,000 inhabitants, the average number of years of schooling for individuals aged 15-30 by governorate in 2006, the population density by governorate in 2006, the natural log of GDP per capita by governorate in 2005/2006 and a dummy variable for fully urban governorates (Cairo, Alexandria, Suez and Port Said). ${ }^{* * *} \mathrm{p}<0.01,{ }^{* *} \mathrm{p}<0.05,{ }^{*} \mathrm{p}<0.1$. Robust standard errors in brackets are clustered at the community level. The reported KleibergenPaap rk Wald F-statistic corresponds to the first stage IV regression F-statistic. The Stock-Yogo weak identification test critical values are 7.03, 4.58, 3.95 and 3.63, at the 10\%, 15\%, 20\% and 25\% maximal IV size respectively. The table also reports the p-value of a test with null hypothesis $\alpha_{1}+\alpha_{2}=0$ to check whether the protests significantly affect women's outcomes of interest. 
Online Appendix Table 16: Labor Force Participation, Unemployment and Employment (prime-aged individuals)

\begin{tabular}{|c|c|c|c|c|c|c|c|c|c|c|c|c|}
\hline \multirow[b]{3}{*}{ VARIABLES } & \multicolumn{4}{|c|}{ Labor Force Participation } & \multicolumn{4}{|c|}{ Unemployment } & \multicolumn{4}{|c|}{ Employment } \\
\hline & (1) & (2) & (3) & (4) & (5) & (6) & (7) & (8) & (9) & (10) & (11) & (12) \\
\hline & OLS & IV & OLS & IV & OLS & IV & OLS & IV & OLS & IV & OLS & IV \\
\hline Martyrs $\times$ female & $\begin{array}{c}0.013^{* * *} \\
{[0.005]}\end{array}$ & $0.088^{* * *}$ & $\begin{array}{c}0.002 \\
50.0117\end{array}$ & $0.132 * * *$ & 0.001 & $0.017 * * *$ & 0.007 & $0.041 * * *$ & $0.012^{* *}$ & $0.071^{* * *}$ & -0.005 & $0.091 * *$ \\
\hline Martyrs & $\begin{array}{c}-0.008^{* * *} \\
{[0.003]}\end{array}$ & $\begin{array}{l}-0.010^{*} \\
{[0.005]}\end{array}$ & $\begin{array}{c}0.003 \\
{[0.005]}\end{array}$ & $\begin{array}{l}-0.015 \\
{[0.012]}\end{array}$ & $\begin{array}{c}-0.004 \\
{[0.003]}\end{array}$ & $\begin{array}{l}-0.008^{*} \\
{[0.004]}\end{array}$ & $\begin{array}{c}-0.004 \\
{[0.005]}\end{array}$ & $\begin{array}{l}-0.010 \\
{[0.010]}\end{array}$ & $\begin{array}{l}-0.004 \\
{[0.004]}\end{array}$ & $\begin{array}{l}-0.002 \\
{[0.006]}\end{array}$ & $\begin{array}{c}0.007 \\
{[0.007]}\end{array}$ & $\begin{array}{l}-0.005 \\
{[0.015]}\end{array}$ \\
\hline Observations & 11,238 & 11,238 & 11,238 & 11,238 & 11,238 & 11,238 & 11,238 & 11,238 & 11,238 & 11,238 & 11,238 & 11,238 \\
\hline R-squared & 0.033 & -0.018 & 0.046 & 0.018 & 0.016 & 0.011 & 0.018 & 0.013 & 0.038 & 0.002 & 0.051 & 0.035 \\
\hline Individual Controls & YES & YES & YES & YES & YES & YES & YES & YES & YES & YES & YES & YES \\
\hline Household Controls & YES & YES & YES & YES & YES & YES & YES & YES & YES & YES & YES & YES \\
\hline Pre-revolution governorate controls & & & YES & YES & & & YES & YES & & & YES & YES \\
\hline $\begin{array}{l}\mathrm{H}_{0}: \alpha_{1}+\alpha_{2}=0 \text { (P-value) } \\
\text { Kleibergen-Paap rk Wald F statistic }\end{array}$ & 0.210 & $\begin{array}{l}0.000 \\
20.52\end{array}$ & 0.650 & $\begin{array}{c}0.001 \\
35.966\end{array}$ & 0.198 & $\begin{array}{l}0.056 \\
20.52\end{array}$ & 0.671 & $\begin{array}{c}0.012 \\
35.966\end{array}$ & 0.019 & $\begin{array}{l}0.000 \\
20.52\end{array}$ & 0.804 & $\begin{array}{c}0.009 \\
35.966\end{array}$ \\
\hline
\end{tabular}

Notes. Each cell represents a coefficient estimate using OLS or IV regressions, where the distance to the capital Cairo and the distance to the capital Cairo interacted with a female dummy are used to instrument the number of "martyrs" by governorate and the interaction term between the number of "martyrs" by governorate and the female dummy. In this regression table, we consider a sample of prime-aged individuals (aged at least 21 years old in 2006). The number of "martyrs" represents the number of fatalities from the $25^{\text {th }}$ of January 2011 to the end of June 2012, by governorate and is expressed in hundreds. A female dummy is included which results from first-differencing our equation in level (from the interaction term between female and 2012 in Equation 1). The dependent variable and all control variables are first-differenced. Labor force participation, unemployment and employment are defined according to the current work status. The reference period for the labor market information is 3 months. The labor force includes all those who are engaged in economic activity for purposes of market exchange and excludes subsistence workers, following the market definition of economic activity (see ILO, 1982). Individual controls include the following variables in first-difference: a dummy variable for ever-married status, three dummies for educational attainment: primary and preparatory education, secondary education (either general or vocational) and above secondary education (either post-secondary institute or university education and above). The reference category is no educational degree (either illiterate or literate without any diploma). Household controls include the following variables in first difference: a rural dummy, an indicator for male headed household, household size, the number of adults aged 15 to 64 years old, a dummy variable for land ownership, an indicator for the head's marital status being single and three dummies for the head of the household's educational attainment. Pre-revolution governorate controls include the following variables as well as their interaction terms with a female dummy: the share of public sector employment by governorate in 2006, the number of police stations by governorate per 10,000 inhabitants, the average number of years of schooling for individuals aged 15-30 by governorate in 2006, the population density by governorate in 2006, the natural log of GDP per capita by governorate in 2005/2006 and a dummy variable for fully urban governorates (Cairo, Alexandria, Suez and Port Said). ${ }^{* * *} \mathrm{p}<0.01,{ }^{* *} \mathrm{p}<0.05$, * $\mathrm{p}<0.1$. Robust standard errors in brackets are clustered at the community level. The reported Kleibergen-Paap rk Wald F-statistic corresponds to the first stage IV regression F-statistic. The Stock-Yogo weak identification test critical values are $7.03,4.58,3.95$ and 3.63, at the 10\%, $15 \%, 20 \%$ and $25 \%$ maximal IV size respectively. The table also reports the p-value of a test with null hypothesis $\alpha_{1}+\alpha_{2}=0$ to check whether the protests significantly affect women's outcomes of interest. 
Online Appendix Table 17: Wage work, self-employment and unpaid family work

\begin{tabular}{|c|c|c|c|c|c|c|c|c|c|c|c|c|}
\hline \multirow[b]{2}{*}{ VARIABLES } & \multicolumn{4}{|c|}{ Wage work } & \multicolumn{4}{|c|}{ Employer/Self-employed } & \multicolumn{4}{|c|}{ Unpaid family work } \\
\hline & $\begin{array}{l}\text { (1) } \\
\text { OLS }\end{array}$ & $\begin{array}{l}\text { (2) } \\
\text { IV }\end{array}$ & $\begin{array}{l}\text { (3) } \\
\text { OLS }\end{array}$ & $\begin{array}{l}\text { (4) } \\
\text { IV }\end{array}$ & $\begin{array}{l}\text { (5) } \\
\text { OLS }\end{array}$ & $\begin{array}{l}\text { (6) } \\
\text { IV }\end{array}$ & $\begin{array}{l}\text { (7) } \\
\text { OLS }\end{array}$ & $\begin{array}{l}\text { (8) } \\
\text { IV }\end{array}$ & $\begin{array}{l}\text { (9) } \\
\text { OLS }\end{array}$ & $\begin{array}{c}(10) \\
\text { IV }\end{array}$ & $\begin{array}{l}\text { (11) } \\
\text { OLS }\end{array}$ & $\begin{array}{l}\text { (12) } \\
\text { IV }\end{array}$ \\
\hline Martyrs $\times$ female & $\begin{array}{c}0.011 * * * \\
{[0.004]}\end{array}$ & $\begin{array}{c}0.051 * * * \\
{[0.012]}\end{array}$ & $\begin{array}{c}0.005 \\
{[0.009]}\end{array}$ & $\begin{array}{c}0.099 * * * \\
{[0.030]}\end{array}$ & $\begin{array}{c}0.005 \\
{[0.003]}\end{array}$ & $\begin{array}{l}-0.009 \\
{[0.007]}\end{array}$ & $\begin{array}{c}-0.004 \\
{[0.007]}\end{array}$ & $\begin{array}{l}-0.042^{*} \\
{[0.024]}\end{array}$ & $\begin{array}{c}0.020^{* * *} \\
{[0.004]}\end{array}$ & $\begin{array}{c}0.056^{* * *} \\
{[0.013]}\end{array}$ & $\begin{array}{c}0.007 \\
{[0.007]}\end{array}$ & $\begin{array}{r}0.110^{* * *} \\
{[0.034]}\end{array}$ \\
\hline Martyrs & $\begin{array}{c}-0.009 * * \\
{[0.004]}\end{array}$ & $\begin{array}{c}-0.042 * * * \\
{[0.010]}\end{array}$ & $\begin{array}{l}-0.005 \\
{[0.008]}\end{array}$ & $\begin{array}{c}-0.080 * * * \\
{[0.026]}\end{array}$ & $\begin{array}{c}-0.002 \\
{[0.003]}\end{array}$ & $\begin{array}{c}0.019 * * * \\
{[0.007]}\end{array}$ & $\begin{array}{c}0.007 \\
{[0.006]}\end{array}$ & $\begin{array}{c}0.056 * * * \\
{[0.020]}\end{array}$ & $\begin{array}{c}0.004^{* * *} \\
{[0.001]}\end{array}$ & $\begin{array}{c}0.012 * * \\
{[0.005]}\end{array}$ & $\begin{array}{l}0.005^{*} \\
{[0.003]}\end{array}$ & $\begin{array}{c}0.010 \\
{[0.010]}\end{array}$ \\
\hline Observations & 14,035 & 14,035 & 14,035 & 14,035 & 14,035 & 14,035 & 14,035 & 14,035 & 14,035 & 14,035 & 14,035 & 14,035 \\
\hline R-squared & 0.070 & 0.060 & 0.071 & 0.060 & 0.013 & 0.005 & 0.015 & 0.007 & 0.042 & 0.021 & 0.048 & 0.021 \\
\hline Individual Controls & YES & YES & YES & YES & YES & YES & YES & YES & YES & YES & YES & YES \\
\hline Household Controls & YES & YES & YES & YES & YES & YES & YES & YES & YES & YES & YES & YES \\
\hline Pre-revolution governorate controls & & & YES & YES & & & YES & YES & & & YES & YES \\
\hline $\begin{array}{l}\mathrm{H}_{0}: \alpha_{1}+\alpha_{2}=0 \text { (P-value) } \\
\text { Kleibergen-Paap rk Wald F statistic }\end{array}$ & 0.298 & $\begin{array}{c}0.073 \\
20.936\end{array}$ & 0.923 & $\begin{array}{c}0.183 \\
39.467\end{array}$ & 0.075 & $\begin{array}{c}0.004 \\
20.936\end{array}$ & 0.178 & $\begin{array}{c}0.199 \\
39.467\end{array}$ & 0.000 & $\begin{array}{c}0.000 \\
20.936\end{array}$ & 0.133 & $\begin{array}{c}0.000 \\
39.467\end{array}$ \\
\hline
\end{tabular}

Notes. Each cell represents a coefficient estimate using OLS or IV regressions, where the distance to the capital Cairo and the distance to the capital Cairo interacted with a female dummy are used to instrument the number of "martyrs" by governorate and the interaction term between the number of "martyrs" by governorate and the female dummy. The number of "martyrs" represents the number of fatalities from the $25^{\text {th }}$ of January 2011 to the end of June 2012, by governorate and is expressed in hundreds. A female dummy is included which results from first-differencing our equation in level (from the interaction term between female and 2012 in Equation 1 ). The dependent variable and all control variables are first-differenced. Wage work, employer, self-employed and unpaid family work are defined according to the current work status in primary job, reference period 3 months. Individual controls include the following variables in first-difference: a dummy variable for ever-married status, three dummies for educational attainment: primary and preparatory education, secondary education (either general or vocational) and above secondary education (either post-secondary institute or university education and above). The reference category is no educational degree (either illiterate or literate without any diploma). Household controls include the following variables in first difference: a rural dummy, an indicator for male headed household, household size, the number of adults aged 15 to 64 years old, a dummy variable for land ownership, an indicator for the head's marital status being single and three dummies for the head of the household's educational attainment. Pre-revolution governorate controls include the following variables as well as their interaction terms with a female dummy: the share of public sector employment by governorate in 2006, the number of police stations by governorate per 10,000 inhabitants, the average number of years of schooling for individuals aged 15-30 by governorate in 2006, the population density by governorate in 2006, the natural log of GDP per capita by governorate in 2005/2006 and a dummy variable for fully urban governorates (Cairo, Alexandria, Suez and Port Said). ${ }^{* * *} \mathrm{p}<0.01,{ }^{* *} \mathrm{p}<0.05,{ }^{*} \mathrm{p}<0.1$. Robust standard errors in brackets are clustered at the community level. The reported Kleibergen-Paap rk Wald F-statistic corresponds to the first stage IV regression F-statistic. The Stock-Yogo weak identification test critical values are 7.03, 4.58, 3.95 and 3.63, at the 10\%, 15\%, 20\% and $25 \%$ maximal IV size respectively. The table also reports the p-value of a test with null hypothesis $\alpha_{1}+\alpha_{2}=0$ to check whether the protests significantly affect women's outcomes of interest. 
Online Appendix Table 18: Informal and formal sector employment

\begin{tabular}{|c|c|c|c|c|c|c|c|c|}
\hline & \multirow{2}{*}{\multicolumn{4}{|c|}{ Informal sector employment }} & \multirow{2}{*}{\multicolumn{4}{|c|}{ Formal sector employment }} \\
\hline & & & & & & & & \\
\hline & (1) & (2) & (3) & (4) & (5) & (6) & (7) & (8) \\
\hline VARIABLES & OLS & IV & OLS & IV & OLS & IV & OLS & IV \\
\hline \multirow[t]{2}{*}{ Martyrs $\times$ female } & $0.018 * * *$ & $0.073^{* * *}$ & -0.006 & $0.096 * * *$ & 0.004 & -0.009 & -0.002 & $-0.039 *$ \\
\hline & [0.005] & [0.019] & {$[0.010]$} & [0.035] & [0.005] & {$[0.008]$} & {$[0.008]$} & {$[0.020]$} \\
\hline \multirow[t]{2}{*}{ Martyrs } & 0.000 & $-0.018 *$ & 0.011 & $-0.052 * *$ & -0.005 & 0.009 & 0.000 & $0.040 * *$ \\
\hline & {$[0.004]$} & {$[0.010]$} & {$[0.008]$} & [0.025] & {$[0.005]$} & {$[0.008]$} & {$[0.008]$} & {$[0.020]$} \\
\hline Observations & 10,649 & 10,649 & 10,649 & 10,649 & 10,649 & 10,649 & 10,649 & 10,649 \\
\hline R-squared & 0.043 & 0.024 & 0.057 & 0.045 & 0.058 & 0.055 & 0.059 & 0.054 \\
\hline Individual Controls & YES & YES & YES & YES & YES & YES & YES & YES \\
\hline Household Controls & YES & YES & YES & YES & YES & YES & YES & YES \\
\hline Pre-revolution governorate controls & & & YES & YES & & & YES & YES \\
\hline $\mathrm{H}_{0}: \alpha_{1}+\alpha_{2}=0$ (P-value) & 0.000 & 0.000 & 0.365 & 0.104 & 0.538 & 0.936 & 0.735 & 0.915 \\
\hline Kleibergen-Paap rk Wald F statistic & & 21.228 & & 44.017 & & 21.228 & & 44.017 \\
\hline
\end{tabular}

Notes. Each cell represents a coefficient estimate using OLS or IV regressions, where the distance to the capital Cairo and the distance to the capital Cairo interacted with a female dummy are used to instrument the number

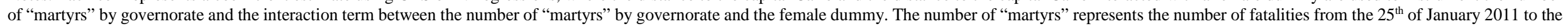
end of June 2012, by governorate and is expressed in hundreds. A female dummy is included which results from first-differencing our equation in level (from the interaction term between female and 2012 in Equation 1). The dependent variable and all control variables are first-differenced. Informal sector employment is defined as having neither a legal work contract nor social security in primary job, reference period 3 months, whereas, formal sector employment is defined as having a legal work contract and social security in primary job, reference period 3 months. Individual controls include the following variables in first-difference: a dummy variable for ever-married status, three dummies for educational attainment: primary and preparatory education, secondary education (either general or vocational) and above secondary education (either post-secondary institute or university education and above). The reference category is no educational degree (either illiterate or literate without any diploma). Household controls include the following variables in first difference: a rural dummy, an indicator for male headed household, household size, the number of adults aged 15 to 64 years old, a dummy variable for land ownership, an indicator for the head's marital status being single and three dummies for the head of the household's educational attainment. Pre-revolution governorate controls include the following variables as well as their interaction terms with a female dummy: the share of public sector employment by governorate in 2006, the number of police stations by governorate per 10,000 inhabitants, the average number of years of schooling for individuals aged 15-30 by governorate in 2006, the population density by governorate in 2006, the natural log of GDP per capita by governorate in 2005/2006 and a dummy variable for fully urban governorates (Cairo, Alexandria, Suez and Port Said). ${ }^{* * *} \mathrm{p}<0.01$, ${ }^{* *} \mathrm{p}<0.05$, ${ }^{*} \mathrm{p}<0.1$. Robust standard errors in brackets are clustered at the community level. The reported Kleibergen-Paap rk Wald F-statistics corresponds to the first stage IV regression F-statistic. The Stock-Yogo weak identification test critical values are 7.03, 4.58, 3.95 and 3.63 , at the $10 \%, 15 \%, 20 \%$ and $25 \%$ maximal IV size respectively. The table also reports the p-value of a test with null hypothesis $\alpha_{1}+\alpha_{2}=0$ to check whether the protests significantly affect women's outcomes of interest. 